\title{
Cyberspace as Place and the Tragedy of the Digital Anticommons
}

\author{
Dan Hunter $\uparrow$.
}

\section{TABLE OF CONTENTS}

Introduction 442

I. Cyberspace as Autonomous Legal Place......................................... 446

A. The History of Cyberspace as a Legal Placc ............................. 447

B. Reconsidering Autonomy and Place........................................ 452

C. City of Bits, Sense of Place .................................................. 454

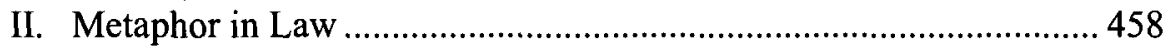

A. Thinking and Talking in Metaphors ….................................... 460

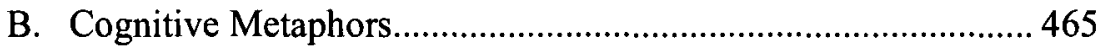

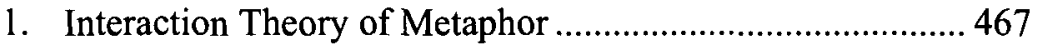

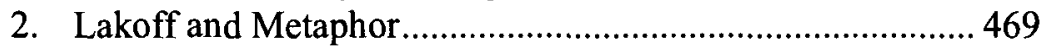

III. Cyberspace as Legal Place ............................................................... 472

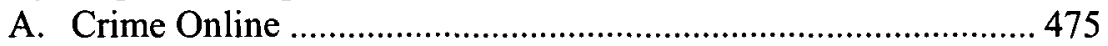

B. Resurrecting Trespass to Chattels......................................... 483

C. The Cyberspace Constitution..................................................... 488

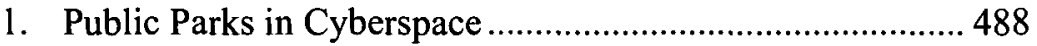

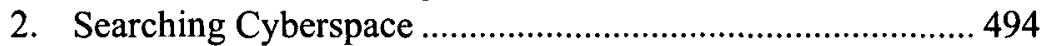

D. Zoning, Jurisdiction, and Names .............................................. 497

IV. The Digital Anticommons …........................................................ 500

A. The Cyberspace Enclosure Movement ...................................... 503

1. Property and Invitees.........................................................504

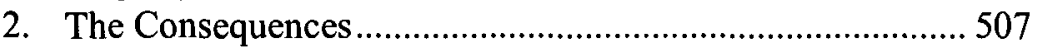

B. The Tragedy of the Digital Anticommons .............................. 509

Copyright $(2003$ Califormia Law Review, Inc. Califormia Law Review, Inc. (CLR) is a Califomia nonprofit corporation. CLR and the authors are solely responsible for the content of their publications.

$\dagger$ Robert F. Irwin IV Term Assistant Professor of Legal Studies, Wharton School, University of Pennsylvania. Email: hunterd@wharton.upenn.edu. I am indebted to John Allison, Michael Birnhack, Brian Bix, Mark Eckenwiler, Orin Kerr, Steve Kobrin, Greg Lastowka, Bill Laufer, Michael Madison, Georgette Poindexter, David Post, Thomas Reidel, Ed Rubin, Tom Ulen, Polk Wagner, Jane Winn, Tim $\mathrm{Wu}$, and especially Mark Lemley, for invaluable advice, comments, and ideas. The usual disclaimer applies. I am grateful for the comments of colleagucs at workshops at the Singapore Management University and the Warrington College of Business of the University of Florida. Stephen Sempill, Veronica Silva-Minin, and Eleonora Vicchi provided invaluable research assistance. Research support came in part from the Wharton Legal Studies Research Fund, the Wharton-Singapore Management University Research Center, and the Jones Center for Management Policy, Strategy, and Organization and the Mack Center for Technological Innovation at the Wharton School. 


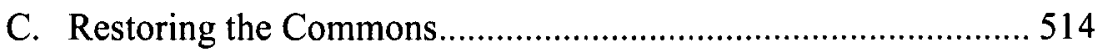

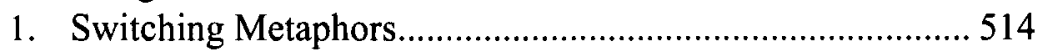

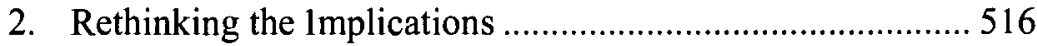

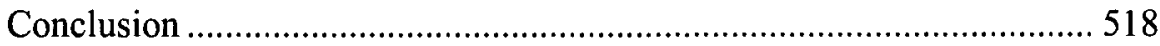




\title{
Cyberspace as Place and the Tragedy of the Digital Anticommons
}

\author{
Dan Hunter
}

Cyberspace was once thought to be the modern equivalent of the Western Frontier, a place where land was free for the taking. This is true no longer. This Article argues that we are enclosing cyberspace and imposing private property conceptions upon it. As a result, we are creating a digital anticommons where suboptimal use of Internet resources will be the norm.

Part I shows why initial discussions of the CYBERSPACE AS PLACE metaphor have confused the descriptive question of how we think about cyberspace with the normative question of how we should regulate cyberspace. It suggests that we can bracket the normative question and still answer the descriptive question of whether we think of cyberspace as a place.

Part II examines the lessons of recent cognitive science studies, and demonstrates the importance of physical metaphors within our cognitive system. It then reviews the evidence of our use of the physical metaphor, CYBERSPACE AS PLACE, in understanding online communication environments.

Part III focuses on this metaphor's unacknowledged and unrecognized influence on the development of the legal framework for the Internet. It examines tortious, criminal, and constitutional law responses to cyberspace, and concludes that the CYBERSPACE AS PLACE metaphor exercises a strong and unrecognized influence on the regulatory regimes of cyberspace.

Part IV details why the effects of that metaphor's use-including the idea that there is property online, and that this property should be privately owned, parceled out, and exploited-are extremely troubling. Though private ownership of resources is not itself problematic, it can lead to the opposite of the tragedy of the commons: the tragedy of the anticommons. Anticommons property occurs when multiple parties have an effective right to prevent others from using a given resource, and as a result no one has an effective right of use. Part IV argues that this is precisely where the CYBERSPACE AS PLACE metaphor leads. We are moving towards a digital anticommons, where no one will be allowed to access 
competitors' cyberspace "assets" without a license or other transactionally expensive or impossible permission mechanism.

This Article explains how the CYBERSPACE AS PLACE metaphor leads to undesirable private control of the previously commons-like Internet and the emergence of a digital anticommons. As we all stake out our little claims in cyberspace, we destroy the cyberspace commons.

\section{INTRODUCTION}

In the early days of computer networks it seemed a slightly far-fetched metaphor to describe... sites as "places," since bandwidth was narrow .... As bandwidth burgeons and computing muscle continues to grow, cyberspace places will present themselves in increasingly multisensory and engaging ways.... We will not just look at them; we will feel present in them.'

Historians will look back to these early years of the twenty-first century as the moment when the tipping point became apparent. It is not too portentous to say that we stand at the fork between two possible futures of intellectual endeavor. Down one road lies a future of completely propertized and privatized ownership of intellectual activity. Down the other road is a future where the interests of society at large are fostered, which at times leads to private ownership of intellectual activity, and at other times demands that some public intellectual space be kept as commons for all.

Others have made this observation within the spheres of intellectual property rights such as copyright ${ }^{2}$ and patent. ${ }^{3}$ The concern also appears to have motivated the Supreme Court's decision to grant certiorari in Eldred v. Ashcroft, a case challenging congressional extension of copyright terms, ${ }^{4}$ even if the Court concluded that the extension was constitutional. However, the focus on intellectual property interests masks the area where the trend to propertize ideas has exerted its most pernicious effect: the Internet.

Cyberspace was once thought to be the modern equivalent of the Wcstcrn Frontier. ${ }^{5}$ It was a place, albeit an abstract place, where land was free for the taking, explorers could roam, and communities could form with

1. Willam J. Mitchell, City of Bits: Space, Place, and the Infobahn 114-15 (1995).

2. See Lawrence Lessig, The Architecture of Innovation, 51 DuKE L.J. 1783 (2002), available at http://www.law.duke.edu/pd/papers/lessig.pdf; James Boyle, The SeCond Enclosure Movement and the Construction of the Public Domain 1-4, at http://www.law.duke.edu/pd/papers/boyle.pdf (last visited Mar. 23, 2002).

3. See Boyle, supra note 2, at 4-5.

4. Eldred v. Reno, 239 F.3d 372 (D.C. Cir. 2001), aff'd sub nom., Eldred v. Ashcroft, 123 S. Ct. 769 (2003).

5. See, e.g., Jonathan J. Rusch, Cyberspace and the "Devil's Hatband", 24 Seattle U. L. Rev. $577,577-79(2000)$. 
their own rules. ${ }^{6}$ It was an endless expanse of space: open, free, replete with possibility. ${ }^{7}$ No longer. As with the Western Frontier, settlers have entered this new land, charted the territory, fenced off their own little claims, and erected "No Trespassing" signs. ${ }^{8}$ Cyberspace is being subdivided. Suburbs and SUVs cannot be far off.

Since cyberspace seems like a place, this trend seems preordained: the progression of property interests over the last five hundred years shows that places tend to be enclosed and privately exploited. ${ }^{9}$ However, it is a surprising trend because legal commentators have convinced us that cyberspace is not a place at all. Some early scholars argued that cyberspace was a separate space for the purposes of law and regulation, ${ }^{10}$ but they were quickly derided for their naïveté. ${ }^{11}$ By the end of the last century, the received wisdom ordained that no one could be foolish enough to argue that cyberspace was a place. ${ }^{12}$

However, the received wisdom has confused the descriptive question of whether we think of cyberspace as a place with the normative question of whether we should regulate cyberspace as a regime independent of national laws. These are two conceptually distinct questions. Whatever the answer to the normative question, cognitive science investigations provide ample evidence that, purely as a descriptive observation, we do think of cyberspace as a place. ${ }^{13}$

Thinking of cyberspace as a place has led judges, legislators, and legal scholars to apply physical assumptions about property in this new, abstract space. Owners of Internet resources think of their systems as their own little claims in cyberspace, which must be protected against the typical encroachments that we find in the physical property world. This has led to a series of cases and statutes that enshrine the idea of property interests in cyberspace. ${ }^{14}$

The effect of this is to take the hitherto commons-like character of cyberspace and splinter it into millions of tiny landholdings. Privatization in this form is not, of itself, a problem: private interests are the dominant forms of resource allocation in our world. However, modern property

6. See Howard Rheingold, The Virtual Community: Homesteading on the Electronic Frontier (1993); see also David R. Johnson \& David Post, Law and Borders-The Rise of Law in Cyberspace, 48 STAN. L. REv. 1367 (1996).

7. See, e.g., Rusch, supra note 5, at 577-79.

8. See infra Parts 111 \& IV.A.

9. See infra Part IV.A.

10. See infra Part 1.A.

11. Id.

12. Timothy Wu, When Law \& the Internet First Met, 3 Green Bag 2d 171 (1999-2000) (noting that the idea of cyberspace as a place "must count as among reeent legal history's more quixotic episodes"); see infra Part I.

13. See infra Part II.

14. See infra Part 111 . 
theorists have demonstrated the dangers of splintering interests: the undesirable consequence is the creation of "anticommons property." Anticommons property emerges where multiple people hold rights of exclusion to a property such that no one has an effective right of use. ${ }^{16}$ As a result, a "tragedy of the anticommons" occurs, where property is locked into suboptimal and wasteful uses because the holders of the exclusion rights block the best use of the resource. ${ }^{17}$

This Article suggests that thinking of cyberspace as a place, and the consequent legal propertization of cyberspace, is leading us to a tragedy of the digital anticommons. Recent laws and decisions are creating millions of splintered rights in cyberspace, and these rights are destroying the commons-like character of the lnternet that has previously led to extraordinary innovation. If we continue down the fork we currently are traveling, we risk creating a digital anticommons that limits many of the innovations we have created to date. Historians will look back on our time and wonderwhen we have seen what the Internet could be-how we could have sat and watched the tragedy of the digital anticommons unfold.

This Article tells a long and complex story, one which concludes that a digital anticommons will result unless we change our conceptualization and legal treatment of the Internet. The starting point is to explore the previous wisdom that cyberspace is not a place for legal purposes. Part I explains the history of this argument and demonstrates why the rcceived wisdom is wrong. It suggests that we have previously confused normative issues with descriptive questions.

With this issue resolved, Part II develops a descriptive theory of how we think about cyberspace. It examines recent theories of cognitive science. ${ }^{18}$ One of the most important theories of cognition demonstrates the importance of physical metaphors within our cognitive system. These metaphors are used, usually unconsciously, in an effort to understand the abstract in terms we recognize from our physical environment. Metaphor is now considered by many cognitive scientists as central in shaping our thinking. It should come as no surprise then that in an arena as abstract as online communications we draw on a conceptual spatial metaphor to structure our thinking.

15. Michael A. Heller, The Tragedy of the Anticommons: Property in the Transition from Marx to Markets, 111 HARv. L. REv. 621, 624-26; infra Part IV.

16. Heller, supra note 15 ; infra Part IV.

17. Heller, supra note 15 ; infra Part IV.

18. Cognitive sciencc is broadly defined as the "long-term enterprise to understand the mind scientifically." David W. Green ET al., Cognitive Science: AN Introduction 2 (1996). It involves the disciplines of computer science, linguistics, neuroscience, philosophy, and psychology, in an effort to understand how the mind works. Id. at 5; see Dan Hunter, Reason Is Too Large: Analogy and Precedent in Law, 50 EMORY L.J. 1197, 1204 (2001). 
Though theories of metaphor form a major category of study in the philosophy of language, in linguistics, and in cognitive science,,$^{19}$ the legal community has largely ignored them. There remains a general perception that law is a "serious" and objective study that should eschew figurative language as much as possible. Justice Cardozo once reminisced about his early days on the bench:

I was much troubled in spirit, in my first years upon the bench, to find how trackless was the ocean on which I had embarked. I sought for certainty. I was oppressed and disheartened when I found that the quest for it was futile. I was trying to reach land, the solid land of fixed and settled rules .... ${ }^{20}$

Many would agree that, in making law, we should prefer Cardozo's "solid land of fixed and settled rules" to the fluid and dangerous sea of metaphor. It is no wonder then that lawyers assume that metaphors are dangerous, often wrong, and best avoided. Against this, I explain the cognitive science view of metaphor, and detail its importance in legal reasoning.

Part III applies these insights from cognitive science to the regulation of cyberspace. It explores the evidence that the metaphor of CYBERSPACE AS PLACE $^{21}$ operates on us all, both in lay discussion of online interactions and in legal analysis. It details a number of different Internet-related legal domains, where judges, legislators, and practitioners have adopted the CYBERSPACE AS PLACE metaphor, whether they realize it or not. For example, traditional views of hacking in cyberspace criminalize it as a "trespass" upon a computer or a computer system. ${ }^{22}$ The application of the CYBERSPACE AS PLACE metaphor within the criminal system is neatly reflected in the application, within the civil sphere, of the tort of "trespass to chattels" in cyberspace. ${ }^{23}$ This tort is now a significant method of protecting against competitive practices that rely upon accessing any Internet resource. Although the "trespass to chattels" action would seem to be directed at the personal property at the edges of the Internet-the web servers, file servers, or email servers-a careful analysis of the language of judges in these trespass cases demonstrates that they actually direct it at real property. Other examples of the "placeness" of cyberspace regulation exist: from the agonized musings over Internet jurisdiction and conflict-of-law questions

19. See, e.g., Warren A. Shibles, Metaphor: An Annotated Bibliography and History (1971); Metaphor: A Bibljography of Post-I970 Publications (J.P. van Noppen et al. eds., 1985) [hereinafter Metaphor]; Metaphor II: A Classified Bibliography of Publications i985 to i990 (J.P. van Noppen \& E. Hols eds., 1990) [hereinafter METAPHOR II].

20. Benjamin N. Cardozo, The Nature of the Judicial Process 166 (1921). The irony of using metaphor to describe a longing for literal language cannot have been lost on as great a stylist as Cardozo.

21. The small capitals used in this Article for metaphors such as "CYBERSPACE AS PLACE" are to distinguish them as conceptual metaphors in the tradition of Lakoff and others. See infra Part II.B.

22. See infra Part lll.A.

23. See infra Part III.B. 
through place-based American constitutional law theories used in a cyberspace context to zoning laws applied to parts of the Internet. These examples are so multifarious that I will suggest that the CYBERSPACE AS PLACE metaphor operates as one of the most compelling theories of how we have regulated cyberspace to date, and how we are likely to regulate it in the future.

This observation leads, in Part IV, to the very disturbing implications alluded to in the opening paragraphs. Using the CYBERSPACE AS PLACE metaphor, we can now see how and why the Internet moved from its open state (circa 1995$)^{24}$ to its increasingly proprietary state. If we accept the CYBERSPACE AS PLACE metaphor, then it is a very short step to assume that there is some kind of property online, and that this property should be privately owned, parceled out, and exploited. This comports with recent concerns about the gradual whittling away of the public domain within intellectual property. James Boyle has called this the "second enclosure movement" after the enclosure movement in England during medieval times, when commons property was fenced off and enclosed as private property. ${ }^{25}$ Part IV demonstrates that we are witnessing a similar process in the "cyberspace enclosure movement." Private interests are reducing the public ownership of, and public access to, ideas and information in the online world. We have seen the recent rise of the "trespass to chattels" action, the extension of criminal liability to competitors' legitimate investigation of rivals' websites, and the increasing importance of website "Terms of Use." These developments move us towards a digital anticommons where no one will be allowed to access others' cyberspace "assets" without using some form of licensing or other transactionally expensive permission mechanism.

The Article concludes that the CYBERSPACE AS PLACE metaphor is leading to undesirable private control of the previously commons-like Internet and the consequent emergence of a digital anticommons. As we all come to stake out our little claim in cyberspace, the commons that is cyberspace is being destroyed.

I

\section{Cyberspace as Autonomous Legal Place}

I think of cyberspace as a place. It may be virtual and abstract, but I conceive of it as a place nonetheless. Let me be bolder: though you may have never consciously thought about the proposition, you also eonceive of cyberspace as a place. Let me go further and suggest that all legislators,

24. See, e.g., Lawrence Lessig, Code and Other Laws of Cyberspace $26-27$ (1999) (contrasting the Chicago and Harvard network access regimes, and arguing that the Internet was initially open and that software code changed the regulatory balance).

25. See BOYLE, supra note 2. 
judges, and lawyers unconsciously think that cyberspace is a place, even though at times they may argue vehemently that it is not.

These are dangerous claims. For those aware of the development of Internet and cyberspace law, arguing that cyberspace is a place will appear either ill-informed or quixotic. Even arguing that we think of cyberspace as a place goes against accepted views. For a brief moment, the legal conception of CYBERSPACE AS PLACE flared, and then was gone. As a legal argument it peaked around 1996, was attacked soon thereafter, and, as one commentator has noted, by the year 2000 one was hard pressed to find anyone foolish enough to subscribe to this theory. ${ }^{26}$ The reason I am foolish enough to defend this theory-indeed to base this entire Article around it-requires an understanding of history.

\section{A. The History of Cyberspace as a Legal Place}

The idea that cyberspace might be regulated as a place stemmed from the early cyberlibertarian conception that cyberspace was different from "here" and so should be accorded some form of autonomy from physical world—or so-called "meatspace"-sovereigns. ${ }^{27}$ At its high point the rhetoric was amusing and intentionally overblown:

Governments of the Industrial World, you weary giants of flesh and steel, I come from Cyberspace, the new home of Mind. On behalf of the future, I ask you of the past to leave us alone. You are not welcome among us. You have no sovereignty where we gather. ${ }^{28}$

The legal reflection of this idea, shorn of its rhetorical excesses, asked: "What is the appropriate mechanism for cyberspace regulation?" The initial answer was that self-regulation was the only appropriate governance structure. Within scholarly discourse, this cyberspace selfgovernance movement was championed most notably by David Johnson and David Post in a seminal 1996 article. ${ }^{29}$ They argued that the Internet

26. Wu, supra note 12, at 171 ("When first introduced, the Internet, as Cyberspace, was introduced as a place.... One is pressed to find that placc in 2000.").

27. See John Perry Barlow, Is There a There in Cyberspace?, at http://www.eff.org/Publications/ John_Perry_Barlow/HTML/utne_community.html (last visited Apr. 1, 2002); see also Esther Dyson et al., Cyberspace and the American Dream: A Magna Carta for the Knowledge Age (Aug. 22, 1994), at http://www.pff.org/position_old.html; Mitchell Kapor \& John Perry Barlow, Across the Electronic Frontier, July 10, 1990 (July 10, 1990), available at http://www.eff.org/pub/Publications/John_Perry_ Barlow/HTML/eff.html, reprinted in Robert B. Gelman \& Stanton McCandlish, Protecting Yourself Online: The Definitive Resource on Safety, Freedom, and Privacy in Cyberspace 14 (1998).

28. John Perry Barlow, A Declaration of the Independence of Cyberspace (Feb. 8, 1996), at http://www.eff.org/Publications/John_Perry_Barlow/barlow_0296.declaration.

29. See Johnson \& Post, supra note 6, at 1387-91; see also David R. Johnson \& David G. Post, And How Shall the Net Be Governed? A Meditation on the Relative Virtues of Decentralized, Emergent Law, in COORDINATING THE INTERNET (Brian Kahin and James H. Keller eds., 1997) (arguing for a decentralized system of Internet governance); David G. Post, Anarchy, State, and the Internet: An 
challenged the power of the nation-state to regulate online behavior, as well as its legitimacy to do so, because there was no longer an obvious method to connect an electronic transaction or communication to a particular nation-state jurisdiction..$^{30}$ As a result, from both the descriptive and normative perspectives, it was no longer obvious that national laws should apply to cyberspace transactions. They concluded that cyberspace should be left to develop its own self-regulatory structures, and that national sovereigns should, under certain circumstances, defer to this new legal environment. $^{31}$

At around the same time, other theorists developed similar arguments in favor of internal self-regulatory structures. These arguments included suggestions that online transactions might be better regulated by a system of norms similar to the Lex Mercatoria, the set of norms that governed merchant transactions in medieval times ${ }^{32}$ or that we might see the rise of the "United States District Court for the District of Cyberspace,"33 among other surprising claims. ${ }^{34}$ At least three major legal symposia related to this

Essay on Law-Making in Cyberspace, 1995 J. ONLiNE L. art. 3 (June 1995), at http://www.wm.edu/ law/publications/jol/articles/post.shtml (same); David G. Post \& David R. Johnson, "Chaos Prevailing on Every Continent": Towards a New Theory of Decentralized Decision-Making in Complex Systems, 73 CHI.-KENT L. REv. 1055 (1998) (applying complexity theory in support of the decentralization argument); David G. Post, Governing Cyberspace, 43 WAYNE L. REv. 155, 161 (1996) (arguing that cyberspace transactions occur in a virtual space).

30. Johnson and Post explain:

The rise of the global computer network is destroying the link betwcen geographical location and: (1) the power of local governments to asscrt control over online behavior; (2) the effects of online bchavior on individuals or things; (3) the legitimacy of a local sovereign's efforts to regulatc global phenomena; and (4) the ability of physical location to give notice of which sets of rules apply. The Net thus radically subverts the system of rule-making based on borders between physical spaces, at least with respect to the claim that Cyberspace should naturally be governed by territorially defined rules.

Johnson \& Post, supra note 6, at 1370.

31. Id. at $1400-02$.

32. See this Part; Trotter Hardy, The Proper Legal Regime for "Cyberspace", 55 U. PITT. L. REv. 993, 1015-25 (1994) (contending that in the absence of some compelling social reason to the contrary, rules of conduct in cybcrspace should bc govcrned by self-hclp, custom, and contract of cyberspace participants, and arguing specifically in favor of recognizing a limited Law-Merchant-like regulatory mechanism); Joel R. Reidenberg, Lex Informatica: The Formulation of Information Policy Rules Through Technology, 76 TEX. L. Rev. 553 (1998) (arguing that rulcs imposed by networks form a "Lex Informatica," analogous to the medieval Lex Mercatoria).

33. Henry H. Perritt, Jr., Jurisdiction in Cyberspace, 41 ViLL. L. Rev. 1, 100-03 (1996).

34. See, e.g., John T. Delacourt, The International Impact of Internet Regulation, 38 HaRv. 1NT'L. L.J. 207 (1997) (arguing for consensual self-regulation as the best way to avoid overly restrictive and parochial national regulations); Henry H. Perritt, Jr., Cyberspace Self-Government: Town Hall Democracy or Rediscovered Royalism?, 12 BeRKELEY TECH. L.J. 413, 419-20 (1997) (contending that as a general rule "self-governance is desirable for elcctronic communities"); Henry H. Perritt, Jr., The Internet is Changing International Law, 73 CHI.-KENT L. Rev. 997 (1998) (arguing that the Internet challenges national sovcreignty, and alters international law as a consequence); Joel R. Reidenberg, Governing Networks and Rule-Making in Cyberspace, 45 EMORY L.J. 911 (1996) (arguing that attempts to dcfine rules for the development of cyberspace rely on disintegrating concepts of territory and ignore the new borders that transcend national boundaries); Shamoil Shipchandler, Note, The Wild Wild Web: Non-Regulation as the Answer to the Regulatory Question, 33 CoRNELL 1NT'L L.J. 435 (2000) 
question ran at this time, ${ }^{35}$ and a significant number of the participants assumed that it was either desirable or inevitable that some form of distinct regulatory structure would apply to cyberspace. ${ }^{36}$ While many different ideas were proffered and many different legal doctrines analyzed, one of the defining, albeit often unstated, characteristics of the arguments of this period was that cyberspace was a place. Another defining characteristic was that cyberspace should be regulated independently of physical, geographically-delimited sovereigns. As a result, there was a strong trend, circa 1996-97, suggesting that cyberspace was, or should have been, an autonomous place for the purposes of regulation. ${ }^{37}$

By 1998 the tide had turned. Jack Goldsmith mounted an influential attack on those he labeled cyberspace "regulation skeptics." was, essentially, that cyberspace created no problems that had not already been resolved by unexceptional jurisdictional rules and legal mechanisms

(arguing that imposing national regulations before the medium stabilizes is ineffeetive since its users will self-regulate); Edward J. Valauskas, Lex Networkia: Understanding the Internet Community, 1 FIRST MONDAY (1996), at http://www.firstmonday.dk/issues/issue4/valauskas/index.html (calling for formalization of Internet self-governance).

35. See Symposium, The Law of Cyberspace, 1996 U. Chi. Legal. F. 437 (1996); Symposium, Surveying Law and Borders, 48 StAN L. Rev. 1037 (1996); The Randolph W. Thrower Symposium on Legal Issues in Cyberspace: Hazards on the Information Superhighway, 45 EMORY L.J. 869 (1996).

36. See, e.g., Richard H. Acker, Choice-of-Law Questions in Cyberfraud, 1996 U. CHI. LEGAL. F. 437 (1996) (examining the inadequaeies of choice-of-law rules in cyberspace); Larry Irving, Safeguarding Consumers' Interests in Cyberspace, 1996 U. CHI. LEGAL. F. 1 (1996) (noting the new spatial characteristics of cyberspace and discussing the national governmental response); M. Ethan Katsh, Software Worlds and the First Amendment: Virtual Doorkeepers in Cyberspace, 1996 U. СH. LEGAL. F. 335 (1996) (applying the First Amendment to the online space); Keith Sharfman, Regulating Cyberactivity Disclosures: A Contractarian Approach, 1996 U. CHI. LeGAL. F. 639 (1996) (arguing for an internal, contractarian approach to eyberspace disclosure problems). But see Frank H. Easterbrook, Cyberspace and the Law of the Horse, 1996 U. CHI. LeGAL. F. 207 (1996) (suggesting that concentrating on cyberspace as a separate regulatory environment was like coneentrating on "The Law of the Horse," rather than the traditional doctrinal bodies of law affecting horses); John K. Halvey, The Virtual Marketplace, 45 EMORY L.J. 959 (1996) (examining the U.S. regulatory response to electronie currcncy, and concluding that existing responses were appropriate); Lawrence Lessig, Reading the Constitution in Cyberspace, 45 EMORY L.J. 869 (1996) (seeking to translate the Constitution into cyberspace and finding the same protections online as offline); Scott K. Pomeroy, Promoting the Progress of Science and the Useful Arts in the Digital Domain: Copyright, Computer Bulletin Boards, and Liability for Infringement by Others, 45 EMORY L.J. 1035 (1996) (charting the application of copyright to bulletin board systems ("BBSs"), and implicitly assuming that the offline law applies online).

37. Some scholars disagreed with aspects of the self-regulatory thesis, while accepting some features of the conception of cyberspace as a separate place. See, e.g., Lawrence Lessig, The Zones of Cyberspace, 48 StAn. L. Rev. 1403 (1996).

38. Jack L. Goldsmith, Against Cyberanarchy, 65 U. CHI. L. Rev. 1199, 1199-1200 (1998) [hereinafter Goldsmith, Against Cyberanarchy]; see also Jack L. Goldsmith, The Internet and the Abiding Significance of Territorial Sovereignty, 5 Ind. J. Glob. Legal. Stud. 475, 479 (1998) (arguing that Internet activities are functionally identical to non-Internet activities and may be regulated in the same manner); Jaek Goldsmith, Unilateral Regulation of the Internet: A Modest Defense, 11 Eur. J. INT'L L., 135 (2000) (same); Allan R. Stein, The Unexceptional Problem of Jurisdiction in Cyberspace, 32 1NT'L LAw. 1167, 1180 (1998) (arguing that the Internet is just a medium and is no different from the myriad of ways that people from one place injure people in other places). 
derived from conflict of laws. ${ }^{39}$ Goldsmith challenged the descriptive argument underlying cyberspace self-regulatory theories: cyberspace was not, he argued, descriptively different from "real space." He concluded that transactions in cyberspaee were no different from those occurring in the space of physical world transnational transactions. ${ }^{40}$ Goldsmith's challenge posed the question: Since we are able to regulate similar matters effectively and appropriately on a national basis, why should we treat cyberspace differently for the purposes of regulation and governance?

Following Goldsmith's descriptive challenge, Neil Weinstock Netanel attacked the normative basis for cyberspace self-regulation. ${ }^{41}$ The core of the normative argument in favor of self-regulation was that "[g]overnments derive their just powers from the consent of the governed." ${ }^{42}$ Netanel identified two specific normative claims that arose in the cyberspace environment based on this social-contractarian, bottom-up governance approach. ${ }^{43}$ First was the claim that cyberspace self-regulation is the perfection of liberal rule since it "embodies the liberal democratic goals of individual liberty, popular sovereignty, and consent of the governed." the claim that a truly liberal state grants autonomy to groups that seek it: if cyberspace is a self-defining community, intrusion by a state amounts to a "eolonial" usurpation of group norms and authority. ${ }^{45}$ Netanel demonstrated that both of these claims were unfounded. He argued that an "unregulated" cyberspace would prove inimical to liberal democratic ideals, in part due to the usual countermajoritarian and tyrannical government concerns, ${ }^{46}$ pragmatic concerns with popular referenda, ${ }^{47}$ and theoretical problems with direct democracy. ${ }^{48}$ As a result, state intervention would be warranted under democratic theory in order to protect the ideals of liberalism. ${ }^{49}$ Even if this did not occur, Netanel argued, cyberspace would develop its own quasi-state institutions in the absence of a state regulatory

39. See Goldsmith, Against Cyberanarchy, supra note 38, at 1239-40. Goldsmith notes:

Transactions in cyberspace involve real people in one territorial jurisdiction either (i) transacting with real people in other territorial jurisdictions or (ii) engaging in activity in one jurisdiction that causes physical world effects in another territorial jurisdiction. To this extent, activity in cyberspace is functionally identical to transnational activity mediated by other means, such as mail or telephone or smoke signal.

Id.

40. See id. at 1250 .

41. See Neil W. Netanel, Cyberspace Self-Governance: A Skeptical View from Liberal Democratic Thcory, 88 CALIF. L. REv. 395 (2000),

42. Barlow, supra note 28.

43. Netanel, supra note 41 , at $402-03$.

44. Id. at 402; see also id. at 410-12.

45. See id. at $402-03,446-51$.

46. See id. at $421-27$.

47. See id. at 417-19 (This includes uneven voter turnout, ambiguous and misleading ballots, and so forth.).

48. See id. at 419-21.

49. See id. at 403. 
structure $^{50}$ These institutions would demonstrate the same democratic deficits that formed the basis of the cyberlibertarian challenge to the state's regulatory legitimacy. ${ }^{51}$ Far from being the perfection of liberal democratic ideals, he argued that cyberspace self-governance would lead to a breeding ground for illiberal activities such as status discrimination, narrowing of content access, systematic invasions of privacy, and gross inequality. ${ }^{52}$

Though these two scholars remain the most influential critics of the idea that cyberspace is, or should be, an autonomous regulatory sphere, other commentators fleshed out additional reasons why the early selfregulation approach was problematic. ${ }^{53}$ Most of these theorists did not argue directly against the CYBERSPACE AS PLACE metaphor, confining themselves to discussing problems with the idea of online self-regulation. However, most of the approaches assumed that eyberspace self-governance arose because the self-regulation advocates considered cyberspace to be a separate place. Furthermore, two theorists, Andrew Shapiro and Timothy $\mathrm{Wu}$, directly attacked the conception of cyberspace as a place. Shapiro, author of the influential cyberspace policy work, The Control Revolution, ${ }^{54}$ argued against the metaphor of cyberspace as an autonomous place. ${ }^{55} \mathrm{His}$ argument mirrors much of what was said elsewhere by cyberspace selfgovernancc critics: what happens in cyberspace happens in the physical world also, ${ }^{56}$ and cyberspace is not a real place but just a medium that we

50. Id. at 403-04.

51. See id. at 484-86. The emergence of the Internet Corporation for Assigned Names and Numbers ("ICANN") bears out his initial observation that online institutions would emerge to fill the regulatory vacuum. Whether this institution suffers from democratic dcficits is beyond the scope of this paper. See Dan Hunter, ICANN and the Concept of Democratic Deficit, 36 LoY. L.A. L. Rev. (forthcoming Mar. 2003).

52. See id. at 497-98.

53. See, e.g., James Boyle, Foucault in Cyberspace: Surveillance, Sovereignty, and Hardwired Censors, 66 U. CIN. L. REv. 177 (1997) (examining modern technology as a surveillance mechanism); Julie E. Cohen, A Right to Read Anonymously: A Closer Look at "Copyright Management" in Cyberspace, 28 ConN. L. Rev. 981 (1996) (discussing digital rights management systems and the effect on anonymous reading); Lawrenee Lessig, The Law of the Horse: What Cyberlaw Might Teach, 113 HaRv. L. Rev. 501, 505-06 (1999). Lessig notes:

Many believe that cyberspaee simply cannot be regulated. . . This belief about cyberspaee is wrong, but wrong in an interesting way. It assumes either that the nature of cyberspaee is fixed-that its architeeture, and the control it enables, cannot be changed-or that government cannot take steps to change this architecture.

Id.; see also Lessig, supra note 37, at 1404 (examining Internet zoning); Andrew L. Shapiro, The Disappearance of Cyberspace and the Rise of Code, 8 SETON HALL CONST. L.J. 703 (1998) (looking at the effect of code and architecture on eyberspaee); Timothy $\mathrm{S}$. Wu, Note, Cyberspace Sovereignty? The Internet and the International System, 10 HARV. J.L. \& TЕCH. 647 (1997) (asserting the dominance of a law over code).

54. Andrew L. Shapiro, The Control Revolution: How the Internet ls Putting Individuals in Charge and Changing the World We Know (1999).

55. See id. (arguing that the Internet creates positive effects in society, but also some problems such as control and personalization); Shapiro, supra note 53, at 704-12.

56. See Shapiro, supra note 53, at 704-11. 
may control. ${ }^{57} \mathrm{He}$ suggested that we are not well served by the idea that cyberspace is an autonomous "place," and that "cyberspace is not elsewhere." 59

Timothy Wu argued much the same, suggesting that it is no longer possible to coneeive of cyberspace as an autonomous place- "the general sense of Cyberspace as one place is missing" ${ }^{10}$ - and further that the metaphor of CYBERSPACE AS PLACE was dead:

The metaphor of place did not exactly stand the test of time. For the Internet, as a whole, did not develop into a kind of other-world kingdom inhabited by netizens; or even, more modestly, develop a real "commons." Yes, many years ago, the mainstay of Internet usage was community-based and somewhat place-like. Users were fewer, more similar in personality, and there was little reason to log on if it wasn't to interact (there was nothing else to do). But the early users of the Internet notwithstanding, the Internet was never designed to be "like" a place. It was designed to be a multiple-use network, capable of supporting any kind of application anyone wanted to run on it.... The metaphor and the technology never matched. ${ }^{61}$

It now should be clear why defending the idea that "cyberspace is a place" appears quixotic. It goes against the recent argument that cyberspace is not a place, and should not be regulated separately from physical space. As Wu pointed out, the metaphor just did not seem to stand the test of time.

\section{B. Reconsidering Autonomy and Place}

The scholars who present the received wisdom are, I think, wrong. They conflate the idea that cyberspace has the characteristics of a place with the debate about cyberspace regulatory autonomy. I do not argue here that cyberspace should be self-regulated. I do argue, however, that judges, legislators, practitioners, and lay people treat cyberspace as if it were a physical place. Examining how people discuss their online interactions, we find a vast amount of evidence that people think about online communications and transactions as occurring in some place. This place may be inchoate and virtual, but no less real in our minds.

If we set aside the issue of how we regulate cyberspace, we still must ask what evidence there is for us thinking of cyberspace as though it were a place. Later in this Article I explain both the theory underlying this

57. See id. at 710-12.

58. Id. at 704 .

59. Id. at 710 .

60. Wu, supra note 12 , at 171 .

61. Id. at 172-73. 
assertion ${ }^{62}$ and extensive evidence of it in law. ${ }^{63}$ However, some evidence is necessary here since my claim runs counter to the received wisdom described above.

First consider how everyone employs physical vocabulary to talk about events, transactions, and systems that exist or occur online. At its most fundamental, think of the term WEB,${ }^{64}$ an allusion to the "web-like" connections between computers. ${ }^{65}$ Then there is the NET, referring to the network of connections as well as the net-like character of the material caught in the network. ${ }^{66}$ We SURF this WEB, MOVING from one SITE to the next, ENTERING or VISITING the site, ${ }^{67}$ or, in the slightly oldfashioned nomenclature, we access someone's HOMEPAGE. ${ }^{68}$ We HANG OUT IN CHATROOMS communicating with our ONLINE buddies. ${ }^{69} \mathrm{We}$ ROAM AROUND Multiple User DUNGEONS and DOMAINS ("MUDs") and MUDs Object Oriented ("MOOs"). ${ }^{70}$ Software programs called ROBOTS, AGENTS, or SPIDERS are allowed to CRAWL over websites ${ }^{71}$ unless they are barred by terms and conditions of ENTRY or ACCESS, ${ }^{72}$

62. Infra Part II.

63. Infra Part III.

64. In this paragraph, words that are fully capitalized indicate terms that have physical connotations.

65. See Mark Sableman, Linked Law Revisted: Internet Linking Law at Five Years, 16 Berkeley TeCh. L.J. 1273, 1274 (2001) (referring to the fact that Tim Berners-Lee's reason for developing the Web was to facilitate making connections between computers).

66. See Xuan-Thao N. Nguyen, Shifting the Paradigm in E-Commerce: Move Over Inherently Distinctive Trademarks-The E-Brand, I-Brand, and Generic Domain Names Ascending to Power?, 50 AM. U. L. REv. 937, 948 (2001) (explaining that the Internet is a network of computers); Rachel J. Posner, Manipulative Metatagging, Search Engine Baiting, and Initial Interest Confusion, 33 Colum. J.L. \& Soc. Probs. 439, 444 n.25 (2000) (noting the difference between the Net, computers connectcd through cables, and the Web, where connections are hyperlinks).

67. See, e.g., ACLU v. Reno, 31 F. Supp. 2d 473, 476, 483 (E.D. Pa. 1999) (mentioning the activity of browsing or surfing the Web), vacated sub nom., Ashcroft v. ACLU, 122 S. Ct. 1700 (2002).

68. See, e.g., Ford Motor Co. v. Great Domains, Inc., 141 F. Supp. 2d 763, 775 (E.D. Mich. 2001) (noting homepages for Ford dealerships).

69. See, e.g., People v. Barrows, 677 N.Y.S.2d 672, 678-79 (N.Y. Sup. Ct. 1998) (explaining how chatrooms or cyberchats function).

70. See, e.g., Robert M. Kossick, The Emerging Disharmony of Electronic Commerce Legislation in Latin America, 9 TUL. J. INT'L \& COMP. L. 387, 389 n.2 (2001) (referring to MUDs and MOOs); Patrick F. McGowan, Global Trademark and Copyright 1996: Management and Protection, in THE Internet and Intellectual Property Issues 1996, at 323, 409 (PLl Patents, Copyrights, Trademarks, \& Literary Property Course, Handbook Series No. G4-3981, 1996) (enumerating different Internet activities, including "roaming around").

71. Ticketmaster Corp. v. Tickets.Com, Inc., 2000 WL 1887522, at *2 (C.D. Cal. Aug. 10, 2000) (speaking of "webcrawlers" or "spiders," computer devices used to obtain information by opening up an interior web page and reading the information off the screen), aff'd, 248 F.3d II 73 (9th Cir. 200I); eBay, Inc. v. Bidder's Edge, Inc., I00 F. Supp. 2d 1058, 1060 (N.D. CaI. 2000) (explaining the function of software robots and giving the different names assigned to them: spiders, web crawlers, and the like); EF Cultural Travel BV v. Explorica, lnc., 274 F.3d 577, 579 (Ist Cir. 200I) (noting the use of bots for screen scraping).

72. See, e.g., Register.com, Inc. v. Verio, Inc., I26 F. Supp. 2d 238, 245 (S.D.N.Y. 2000) (referring to WHOIS database terms and conditions to entry into the Web-enabled database). 
or by the robot EXCLUSION standard. ${ }^{73}$ We NAVIGATE the WEB ${ }^{74}$ using computer programs with names like NAVIGATOR and EXPLORER. ${ }^{75}$ We use Uniform Resource LOCATORS ("URLs")" and DOMAIN names $^{77}$ to find our way. Information is sent to us using hypertext TRANSPORT protocol ("http") or simple mail TRANSPORT protocol. ${ }^{78}$ We use email ADDRESSES ${ }^{79}$ to send messages to others, and the machines themselves use Internet Protocol ("IP") ADDRESSES to locate other computers. ${ }^{80}$ We $\log$ INTO or log ONTO our Internet Service Provider ("ISP"). ${ }^{81}$ Malignant wrongdoers ACCESS our accounts by hacking INTO the system using BACKDOORS, TRAPDOORS, or stolen $\mathrm{KEYS},{ }^{82}$ and engage in computer TRESPASSES. ${ }^{83}$

\section{City of Bits, Sense of Place}

Apart from linguistic usage, other evidence from "sense of place" geographers teach us to think that cyberspace is a place. In I990 Mitch Kapor and John Perry Barlow penned a manifesto that led to the creation of the

73. This is done typically by online "Terms of Use." See infra Part IV. Barring may also occur via the robots.txt file on the wcbsite. See The Robot Exclusion Standard, at http://info.webcrawlcr.com/mak.projects/robots/norobots.html (last visited 1 April, 2002). For legal implications, see eBay, Inc., $100 \mathrm{~F}$. Supp. 2d at 1061 (using the robot exclusion standard as basis for de-authorizing access to publie database).

74. Reno v. ACLU, 521 U.S. 844, 852 (1997) ("Navigating the Web is relatively straightforward.").

75. Old hands may recall that when Microsoft finally recognized the commercial possibilities of the Internet, its slogan changed to "Where do you want to go today?" See, e.g., Richard P. Rollo, The Morass of Internet Personal Jurisdiction: It Is Time for a Paradigm Shift, 51 FLA. L. Rev. 667, 668 (1999).

76. See, e.g., America Online, lnc. v. Huang, 106 F. Supp. 2d 848, 849 (E.D. Va. 2000) (defining domain names, URL, and http); Eolas Technologies, Inc. v. Mierosoft Corp., No. 99-C0626, 2000 WL 1898853, at *1 (N.D. 111. 2000) (defining URL and its function).

77. See, e.g., Virtual Countries, Inc. v. Republic of South Africa, 148 F. Supp. 2d 256, 260 (S.D.N.Y. 2001) (considering the inclusion of geographical terms within the domain name system), aff'd, 300 F.3d 230 (2d Cir. 2002); Kenneth L. Port, Japanese Intellectual Property Law in Translation: Representative Cases and Commentary, 34 VAND. J. TRansnat'L L. 847, 883-84 (2001) (describing the function of domain names).

78. See, e.g., Huang, 106 F. Supp. $2 \mathrm{~d}$ at 849 (defining domain names, URL, and http); Jonathan B. Postel, Simple Mail Transfer Protocol (RFC 821) (Aug. 1982), at http://www.isi.edu/innotes/rfc821.txt (defining smtp).

79. See, e.g., Sprint Corp. v. DeAngelo, 12 F. Supp. 2d 1188, 1192 (D. Kan. 1998) (explaining the function of email addresses).

80. See, e.g., Columbia Ins. Co. v. seescandy.com, 185 F.R.D. 573, 575 (N.D. Cal. 1999) (describing the function and characteristics of IP addresses).

81. See, e.g., SightSound.Com, Inc. v. N2K, Inc., 185 F. Supp. 2d 445, 462 (W.D. Pa. 2002).

82. Donn B. Parker, Fighting Computer Crime: A New Framework for Protecting INFORMATION 90-91 (1998).

83. See infra Part 111.B. Many other physical metaphors are used within cyberspaee and to characterize abstract features of computer systems: VIRUSES, WORMS, BUGS, and TROJAN HORSES INFECT the system; WORMS and CRAWLERS MIGRATE the net; the desktop interface represents internal components (disk drives and files) of the computer, using WINDOWS, TRASH CANS, and so forth. 
Electronic Frontier Foundation, an online civil liberties group. ${ }^{84}$ Entitled Across the Electronic Frontier, the manifesto adopted the term "cyberspace" as well as a series of spatial metaphors for aspects of the Internet. ${ }^{85}$ During this early phase of cyberspace evolution, the development of electronic communities was the subject of significant deseription and discussion. The "frontier" was pushed back by electronie homesteaders, and they were eager to provide their accounts of this new virtual place and the communities inhabiting it. Howard Rheingold's The Virtual Community $^{86}$ (subtitled Homesteading on the Electronic Frontier) explained the construction of new kinds of virtual places ${ }^{87}$ the emergence of community structures, ${ }^{88}$ and other early examples of how spatially based community expectations were moved into cyberspace. ${ }^{89}$

Apart from first-person accounts of the lives lived in that abstract space, a number of theorists-usually geographers, architects, or urban planners-began examining the spatial characteristics of the online world..$^{90}$ These scholars explained how we generate a sense of place in the physical world, and how this sense of place mapped to the virtual world. The most influential theorist was the dean of Massachusetts Institute of Technology's School of Architecture and Planning, William Mitchell, who provided the fundamentaI roadmap of the online world in his seminal book, City of Bits. ${ }^{91}$

Mitchell's work demonstrated how we effortlessly transpose an enormous number of our physical understandings of our environment into our understanding of the online world. ${ }^{92}$ He showed, for example, the presence

84. See Electronic Frontier Foundation, at www.eff.org (last visited Apr. 1, 2002).

85. Kapor \& Barlow, supra note 27. For example, the opening paragraphs read:

Over the last 50 years, the people of the developed world have begun to cross into a landscape unlike any which humanity has experienced before. It is a region without physical shape or form. It exists, like a standing wave, in the vast web of our electronic communication systems. It consists of electron states, microwaves, magnetic fields, light pulses and thought itself.

It is familiar to most people as the "place" in which a long-distance telephone conversation takes place. But it is also the repository for all digital or electronically transferred information, and, as such, it is the venue for most of what is now commerce, industry, and broad-scale human interaction. William Gibson called this Platonic realm "Cyberspace," a name which has some currency among its present inhabitants.

Whatever it is eventually called, it is the homeland of the Information Age, the place where the future is destined to dwell.

Id.

86. RHEINGOLD, supra note 6.

87. See id. at $25-56$.

88. See id. at 181-204, 231-54.

89. See, e.g., id. at 255-90 (detailing online activism); id. at 323-42 (describing the existence of a community separate from the BBS service provider that provided the physical network system).

90. See infra note 92 .

91. See MiTChelL, supra note I.

92. Earlier sense-of-place geographers had presented understandings of place that led to Mitchell's insights. See, e.g., Tony Hiss, The Experience of Place (1990); Kevin Lynch, The IMAGE OF THE CITY (1960). For earlier analyses of media, telecommunications, and cyberspace within 
of public and private spaces online: the Web is public, as are many chatrooms, whereas email is private. ${ }^{93}$ He examined how our use of the space is similar to our uses of physical world space. We promenade along the public spaces. ${ }^{94}$ We explore frontier regions,${ }^{95}$ urban neighborhoods, ${ }^{96}$ and imaginary worlds. ${ }^{97}$ We name the spaces we inhabit with titles that reflect our personality or the usage of the space: chatrooms are called "The Flirt's Nook" or "StarFleet Academy"98 and the like. ${ }^{99} \mathrm{He}$ described the various physical spaces that were being directly "moved" into the online environment. These ranged from schools to stock exchanges to prisons. ${ }^{100}$

Identifying spatial characteristics led quickly to the mapping of cyberspace. ${ }^{101}$ On one hand, designers of abstract spaces adopted a map-like metaphor as an interface to the various services they provided. Early

the sense-of-place framework, see Joshua Meyrowitz, No Sense of Place: The Impact of Electronic Media on Social Behavior 7 (1985). Subsequent researchers fleshed out other features of the online landscape. See Manuel Castells, Information Age 1-3 (1996-1998); Stephen Graham \& Simon Marvin, Telecommunications and the City: Electronic Spaces, Urban Places (1996); Stacy Horn, Cyberville: Clicks, Culture, and the Creation of an Online Town (1998); William J. Mitchell, E-Topia: "Urban Life, Jim-But Not as We Know It" (1999); Neil Postman, Technopoly: The Surrender of Culture to Technology (1992); ViRTUAL Dimensions (John Beckman ed., 1998).

93. See Mitchell, supra note 1, at 23 ("Many of the places in cyberspace are public, like streets and squares; access to them is uncontrolled. Others are private, like mailboxes and houses, and you can enter only if you have the key or can demonstrate that you belong.").

94. See id. at 24 ("Cliek, click through cyberspace; this is the new architectural promenade.").

95. See id. at 109 ("The early days of cyberspace were like thosc of the western frontier. Parallel, breakneck development of the Internet and of consumer computing devices and software quickly ereated an astonishing new condition; a vast, hitherto-unimagined territory began to open up for exploration."); see id. at 110 . Mitchell wrote:

In its present condition... cyberspace is a frontier region, populated by the few hardy technologists who can tolerate the austerity of its savage computer interfaces, incompatible communications protocols, proprietary barricades, cultural and legal ambiguities, and a general lack of useful maps and metaphors... Certainly, the old concepts of property, expression, identity, movement, and context, based as they are on physieal manifestation, do not apply succinctly in a world where there can be none.

Id. (quoting Kapor \& Barlow, supra note 27).

96. See id. at 118 (MUDs "are the cyberspace equivalents of urban neighborhoods.").

97. See id. at 120 (describing online gaming worlds like Habitat). For more modern online communities, see J.C. Herz, 50,000,000 Star Warriors Can't Be Wrong, WIRED, July 2002, at 114 (describing newer gaming worlds like Star Wars Galaxies, Ultima Online, Asheron's Call, and EverQuest). For a discussion of online eommunities not revolving around gaming, see Richard $\mathrm{L}$. Colvin, Cartoon Lips, Virtual Fashion and Physics, L.A.Tımes, July 8, 2002, at El (describing Whyville, an online community for teenage girls).

98. See Mitchell, supra note 1, at 22 ("Shared 'rooms' on the Net often announce themselves by descriptive or allusive names (like the signs on bars and other hangouts)-The Flirt's Nook, Gay and Lesbian, Red Dragon Inn, Romance Connection, Starfleet Academy, Teen Chat, Thirtysomething, Born-Again Onliners, Pet Chat, and so on.").

99. As an example of the change possible within the spatial metaphor, Yahoo was originally organized by electronie neighborhoods, such as "Bourbon St.," but this was abandoned favor of the flexibility of elubs. See Thomas A. Horan, Digital Places: Building Our City of Bits 18 (2000). Either way, we still rely on a spatial metaphor.

100. See Mitchell, supra note 1, at 80-85.

101. See generally Martin Dodge \& Rob Kitchin, Mapping Cyberspace (2001). 
examples included Apple Computer's eWorld ${ }^{102}$ and the city of Cleveland's FreeNet. ${ }^{103}$ In eWorld the various services available were displayed on the screen as a kind of small town. For example, email services were available from the building labeled "Post Office" and administrative functions were found at "City Hall." 104 In FreeNet, the online services offered by Cleveland were found in different "buildings" available online. ${ }^{105}$ Many other examples are familiar from the earliest days of the network: virtual libraries were often visualized exactly like their physical counterparts (with stacks, reference sections, help desks, and so forth) in order to assist navigation, searching, and use. ${ }^{106}$ More recently we have begun seeing spatial visualizations of online resources that attempt to reflect features of the physical world to make human interaction more meaningful. The New York Stock Exchange ("NYSE") built a three-dimensional trading floor, called 3DTF, as a real-time decision support tool for operators. ${ }^{107}$ The visualization is a photo-realistic simulacrum of parts of the NYSE trading floor, complete with trading posts, tickers, and a Bloomberg screen. ${ }^{108}$ Other approaches are not nearly as elaborate. Sitemaps, now a common feature of websites, provide an abstract overview of the pages and services available on the site. ${ }^{109}$ These may be arranged as a simple hierarchical tree or in more imaginative ways. The sitemap of the British Yellow Pages, for example, appropriates the London Underground map as a reference. ${ }^{110}$

The mapping of cyberspace is by no means confined to this appropriation of explicit physical references, nor is it confined to the Cartesian or Newtonian mapping of objects. ${ }^{111}$ Abstract spaces can now be readily mapped and visualized. Online objects, users, services, and relationships are now the subject of cartographic experiments. Examples of maps of cyberspace now include infrastructure and network maps, ${ }^{112}$ IP address space diagrams, ${ }^{113}$ maps of domain name concentrations, ${ }^{114}$ Usenet traffic flow

102. See MitChell, supra note 1 , at 106.

103. See id. at 129.

104. Id. at 106.

105. Id. at 127-29.

106. See HoRAN, supra note 99, at 64.

107. DODGE \& KiTCHIN, supra note 101, at 124.

108. Id. at 124-25.

109. Id. at $117-20$.

110. Id. at 119. This is a neat reflection of an observation that Mitchell makes about movement through virtual space. See Mitchelt, supra note 1, at 118. Mitchell wrote:

[A]s 1 see it, 1 jump almost instantaneously from virtual place to virtual place by following the hyperlinks that programmers have established-much as 1 might traee a path from station to station through the London Underground. If I were to diagram these connections, 1 would Id. have a kind of subway map of cyberspace.

111. DodGe \& KiTchin, supra note 10I, at 28-3I.

112. Id. at $82-88$.

113. Id. at 87 .

114. Id. at 88 . 
visualizations, ${ }^{115}$ network congestion diagrams, ${ }^{116}$ "topological" maps of the concentrations of materials around particular news topics, ${ }^{117}$ and arcrelation diagrams of real-time messaging relationships. ${ }^{118}$ There are even "satellite" maps and "urban density" maps of online multiuser spaces. ${ }^{119}$

The point here is not to document exhaustively all of the evidence that supports the notion that we conceive of cyberspace as a place. Rather, it is merely to demonstrate that the language that we use to discuss cyberspace is shot through with physical references and implications, and that geographers have mapped out these places. Even those who argue against the CYBERSPACE AS PLACE metaphor find it impossible to talk about Internet regulation without invoking spatial references. For example, while arguing in favor of setting aside public forums on the Internet, Andrew Shapiro specifically applied the CYBERSPACE AS PLACE metaphor-including references to online bookstores, online shopping malls, meandering down the cyberspace boulevards, and so on. ${ }^{120}$ The physical world of stores, places, and roads was translated online into an abstract space that shared all the spatial characteristics of the physical world.

All of the above evidence proves little on its own. We need some more comprehensive account of why we think of cyberspace as a place, and some indication that our linguistic utterances and our maps reflect a deeper understanding of cyberspace. Cognitive psychological theories of how we construct our understanding of the world provide this account. Thesc theories-theories that focus on the importance of physical metaphors in our cognitive processes-form the subject of Part II.

II

\section{METAPHOR IN LAW}

Even the most fastidiously objective lawyer must agree that metaphor is useful in law, as it is in all language. To say that we will "pierce the corporate veil" is more evocative than saying we will "make company shareholders or directors personally liable for defaults of a company." Or suggesting that a particular case is "seminal" or the "touchstone" of its field carries more meaning than saying merely that the case is important.

115. Id. at 97.

116. Id. at 116, Plate 3.

117. Id. at 116.

118. Id. at $133-41$.

119. Id. at $153-60$.

120. See Andrew L. Shapiro, Street Corners in Cyberspace, NATION, July 3, 1995, available at http://www.eorpwatch.org/trac/internet/whoowns/streetcorners.html (last visited April 1, 2002) (describing explorations in "a virtual world called Cyberkeley"). For a similar use of physical charaeteristies of the metaphor in cyberlaw thinking, see Lessig, supra note 37 (discussing in detail the features of the arehitecture of eyberspace). 
Metaphors are more evocative and conjure up more associations than their purely literal counterparts. But is this all they do? Are they merely rhetorical "flourishes," which may leaven language, but which are not vital to the way we express or conceive ideas? For a long time, this was the dominant view in philosophy and linguistics. ${ }^{121}$ At its most charitable, this view suggested that metaphor was sometimes useful, but never essential, to the way we express ideas. This view also held that metaphor was not necessary for us actually to think our ideas. Strictly applied, this theory's focus on the persuasive character of metaphor led to its denigration even as a form of speech. Metaphors and other rhetorical features were "devices" thought to mislead and deceive, and were thus the subject of great opprobrium.

In the last few decades, however, linguists, philosophers, and cognitive scientists have suggested that metaphor is more central to language and thought than previously believed. Metaphor has been rehabilitated within philosophical and cognitive science circles and become the subject of great interest. It is now recognized that metaphor shapes our thinking in subtle ways not captured by a purely literal conception of thought. As a result, metaphor studies have burgeoned. They now form a major category of study in the philosophy of language, in linguistics, and in cognitive science. ${ }^{122}$

However, legal scholars seem to have ignored this new interest. Few legal articles and even fewer legal books devote themselves to the study of recent metaphor theories. ${ }^{123}$ The purpose of this Part is to challenge the perception that metaphor is largely irrelevant to law. It demonstrates that metaphor is central to legal thinking and argues that metaphors form a structuring constraint that profoundly influences the legal decision-making process. It shows, by referencc to modern theories of the mind, that metaphors are not mere rhetorical devices but rather part of a larger cognitive model that we all hold. This Part also discusses how metaphors structure our thinking about the world. Here I examine the pervasive presence of metaphor in our thinking, and explain one particular cognitive science theory of how metaphors affcct abstract thinking: the Lakoffian interaction theory. This appreciation of metaphor will illuminate the discussion, in

121. Mark Johnson, The Body in the Mind: The Bodily Basis of Meaning, Imagination, AND REASON $x i x-x \times x v(1987)$.

122. See the vast number of works cited in the bibliographies of SHIBLES, supra note 19; METAPHOR, supra note 19; METAPHOR II, supra note 19.

123. The most important exception is the work of Steven L. Winter. See, e.g., STEven L. Winter, A Clearing in the Forest: Law, Life, and Mind (2001); Stephen L. Winter, The Metaphor of Standing and the Problem of Self-Governance, 40 STAN. L. Rev. 1371 (1988); Steven L. Winter, The "Power" Thing, 82 VA. L. REv. 721 (1996); Steven L. Winter, Transcendental Nonsense, Metaphoric Reasoning, and the Cognitive Stakes for Law, 137 U. PA. L. Rev. 1105 (1989). 
Part III, of how we structure our understanding of cyberspace and the legal issues around it.

\section{A. Thinking and Talking in Metaphors}

I.A. Richards, one of the seminal philosophers of metaphor, suggested that metaphor is so central to our ability to express ideas that we would be unable to speak without relying on metaphorical concepts. ${ }^{124}$ A cynical, "objective" lawyer might question the importance of metaphor and would probably disagree with Richards's assertion. A quick glance at any newspaper would prove her wrong. Newspapers reflect how we discuss current events, and their text is replete with metaphorical expression. Yet the use of metaphor is so widespread and commonplace that we barely recognize the language as metaphorical and not literal. For example, take a front page of The New York Times at random. ${ }^{125}$ It is a "feast" of metaphors: ${ }^{126}$

President Bush SOUNDS concern with the stock MARKET TUMBLING, amid GROWING fears of economic problems associated with the STEEP SELL-OFF of stocks. He CONVEYED a GLANCING sense of optimism, after allegedly TALKING DOWN the economy as a way of BUILDING SUPPORT for his tax cut.

Yugoslavian troops had re-entered the ZONE bordering Kosovo because of SPREADING attacks by gunmen on the OUTSKIRTS of certain towns. With BELGRADE RUN by democrats, the soldiers sought to SEAL routes against smugglers.

In Laredo, TX, the FRUITS of NAFTA trading were CHOKING the city, with the SPRAWL of warehouses and the BURDENS of NAFTA and trucking causing damage. Local Interstates to POINTS NORTH, especially the north-south ARTERY were BACKED UP with 18-wheelers, since Laredo is the HAND-OFF POINT for trade between Mexico and the U.S. The BUSH ADMINISTRATION was negotiating the problem with Mexico. ${ }^{127}$

124. I.A. Richards, The Philosophy of Rhetoric 92 (I936) ("We cannot get through three sentences of ordinary fluid discourse without [metaphor] . ...").

125. N.Y. TIMEs, Mar. 15, 2001, at AI. This just happened to be the newspaper I was reading on the day I wrote this section. Other days, other papers, and indeed all other language, are equally full of metaphor. To give another example, some years ago $I$ undertook an analysis of an English newspaper in the same way. Some examples of metaphorieal usage on the front page of this paper: Water had been discovered on the moon. It was thought to be our PASSPORT to the planets. It meant that the Moon is a STEPPING-STONE that is CALLING US into space. The water OPENS THE WAY for settlement of our NEAREST NEIGHBOR and OPENS UP space for us. We could expect a RUSH of interest in exploration, perhaps leading even to an EPIC NUMBER of rocket launches to the HIGH FRONTIER. And so on. Guardian (London), Mar. 6, 1998, at 1

126. As in the examples given in Part I.B, supra, all terms with metaphorical content are fully capitalized.

127. Some might take exception at the suggestion that the exprcssions "run," "Belgrade," "backedup," and "Bush administration" are metaphorical. These are metaphors, but they can be understood as 
Our cynical lawyer might suggest that this florid language is restricted to newspapers. Surely we would not find this in law, that bastion of objectivity. Taking a few pages of a case at random, ${ }^{128}$ we find judicial verbiage no less metaphor laden. In the recent Supreme Court case Bush v. Gore, ${ }^{129}$ Justices write of MARGINS OF VICTORY, ${ }^{130}$ one party WINNING the electoral RACE, ${ }^{131}$ DIMINISHED MARGINS ${ }^{132}$ as a consequence of the UNDERVOTES ${ }^{133}$ or possibly OVERVOTES, ${ }^{134}$ the DEADLINE ${ }^{135}$ for election RETURNS, ${ }^{136}$ the SHARP FOCUS ${ }^{137}$ of the issues, the EXERCISE $^{138}$ of federal functions, the BRANCHES ${ }^{139}$ and MACHINERY ${ }^{140}$ of government (which needs a little PLAY in its JOINTS), ${ }^{141}$ the SAFE HARBOR provisions of 3 U.S.C. $\S 5,{ }^{142}$ the WEIGHT ${ }^{143}$ of each vote, and the DISCHARGE ${ }^{144}$ of duties of electors; to say nothing of the usual legal metaphors of PETITIONS for RELIEF, ${ }^{145}$ VESTING of powers, ${ }^{146}$ REVERSING ${ }^{147}$ or VACATING ${ }^{148}$ decisions, examination of the HOLDINGS ${ }^{149}$ of prior cases, and so forth.

\footnotetext{
"conventional" metaphors: metaphors that are so commonly used that we do not even think of them as metaphorical at all. Bipin Indurkhya was surprised when a referee of his marvelous book objected to his characterization of the following as metaphorical: "The chairman of the meeting plowed through the agenda." Though there is the literal meaning of plow, being "to turn the earth," Indurkhya notes that "one reviewer of this manuscript objected to my using the... statement as an example of metaphor.... To her, the ... description of a meeting was not metaphorical at all ..." BIPIN INDURKhya, METAPHOR AND COGNITION: AN INTERACTIONIST APPROACH I6 (I992). The same is true of the eonventional metaphors 1 use here, such as "Belgrade," "Bush administration," and so forth. "Belgrade" is a conventional metaphor meaning the government or sovereign power of Serbia. We say "the Bush administration negotiated with Mexico" when what we really mean is: A representative of the United States Federal government, especially the Bush-appointed executive standing as the sovereign in respect of this transaction, negotiated with her equivalent in the Mexican government. Indurkhya explains that "[c]onventional metaphors are those metaphors that are so much a part of everyday speech that they seem hardly metaphorical... Conventional metaphors are evidence to the fact that metaphoric transferenee is not something confined to poetry and literature, but is very much part of our everyday speech." $I d$. at 1-2.
}

128. I have not fixed this either. The case mentioned was the first one that I had on hand.

129. 531 U.S. $98(2000)$.

130. Id. at 528 .

13I. Id.

I32. Id.

133. Id. at 531-32.

I34. Id. at 531.

I35. Id. at 528 .

I36. Id.

137. Id. at 529 .

138. Id. at 533 (Rehnquist, C.J., concurring).

I39. Id. at 534 ; id. at 540 (Stevens, J., dissenting).

140. Id. at 541 (Stevens, J., dissenting).

141. Id.

[42. Id. at 534, 538 (Rehnquist, C.J., concurring).

[43. Id. at 529 .

I44. Id. at 533 (Rehnquist, C.J., concurring).

[45. Id. at 528 .

I46. Id. at 533 (Rehnquist, C.J., concurring).

I47. Id. at 539 . 
I have belabored the point in order to demonstrate that metaphors are omnipresent; to show that in fields as diverse as journalism, law, and even science, ${ }^{150}$ we use metaphor constantly and unconsciously. Then there is, of course, the field of literature, where the discipline depends almost entirely on figurative language. ${ }^{151}$ Far more than rhetorical flourishes used in, say, commentary about sports ("You live by the 3-point shot, you run the risk of dying by it" ${ }^{\text {"152 }}$, metaphors are imbedded in all forms of written and spoken language.

Our cynical lawyer still might hold the view that metaphor is just a linguistic device. Indeed, this had been the commonly held conception of metaphor for thousands of years in both philosophical and legal thinking. Philosophy has shown a historical distrust of metaphor. John Locke had a particularly jaundiced view of metaphor:

But yet if we would speak of things as they are, we must allow that... all the artificial and figurative applications of words eloquencc hath invented, are for nothing else but to insinuate wrong ideas, move the passions, and thereby mislead the judgment; and so indeed are perfect cheats: ...they... cannot but be thought a great fault, either of the language or person that makes use of them. ${ }^{153}$

The distrust has been widespread and longstanding. Its earliest expression can be found in Socrates and Plato, particularly in Plato's quarrel between "philosophy and poetry" and his suggestion in The Republic that the poets' "art corrupts the minds of all who hearken to them, save only those whose knowledge of reality provides an antidote." 154 However, in Ancient Greece rhetoric was seen as a powerful form of argumentation, not merely a persuasive trick. Thus, Aristotle suggested a more positive view: "The greatest thing by far is to be master to metaphor. It is the one thing that cannot be learnt from others; and it is also a sign of genius, since a good

148. Id. at 537.

149. Id. at 535 .

150. See, e.g., K.K. Cetina, Metaphors in the Scientific Laboratory: Why Are They There and What Do They Do?, in From a Metaphorical Point of View: A Multidisciplinary Approach to the Cognitive Content of Metaphor 329, 335-46 (Zdravko Radman ed., 1995) (discussing examples of WAVE and PACKET theories of light, and describing subatomic particles as having COLOR, CHARM, and SPIN).

151. There are so many references to the use of metaphors in literature that it is pointless to single out any. However, Part II.B.2., infra, discusses the work of George Lakoff \& MARK Turner, More than Cool Reason: A Field Guide to Poetic Metaphor (1989), and shows how, in both law and literature, metaphors demonstrate a balance between complete freedom of expression and the constraints of how we think.

152. Joe Drape, Duke Going with New Math: Counting by 3 's to the Crown, N.Y. TIMEs, March 15, 2001, at Dl.

153. John Locke, 2 An Essay Concerning Human Understanding 146-47 (Alexander C. Fraser ed., Oxford, Clarendon Press 1894) (1690).

154. Plato, The Republic 285. 
metaphor implies an intuitive perception of the similarity in dissimilars."155 Nonetheless, philosophers of this era generally shared the view of metaphor that emphasized its linguistic deviance from proper usage. Aristotle's Poetics, on which much of the traditional view of metaphor is based, suggested that metaphor consists of giving one thing a name that "properly belonged to something else."156

The metaphor-as-deviance conception gathered strength. In the seventeenth century the modeI of language and language comprehension came to be based on mathematics. The Age of Reason did not value even the subsidiary persuasive aspects of metaphor that the Ancient Greeks admired. Hence was born the suspicion of metaphorical language, shown in Locke's "perfect cheats" metaphor. ${ }^{157}$ The Age of Reason took as its foundation the idea that rational thought was the highest human virtue, and that rhetorical embellishments merely flawed or masked the perfection of properly reasoned thought. 158

Moving forward in time, literal language became increasingly valued, just as figurative expression became more and more suspect. Ideallanguage philosophy and logical positivism in the twentieth century were simply the culmination of work done over centuries. ${ }^{159}$ Both movements shared the view that language is fundamentally literal and sought to express what was true and verifiable. ${ }^{160}$ Since metaphors inevitably are not literally true and have troubling referents, they were seen as descriptively meaningless and unworthy of serious scientific or philosophical study. ${ }^{161}$ Though logical positivism is no longer a dominant force in philosophy, the influence of hundreds of years of "logical" thinking about figurative language remains. ${ }^{162}$ Mark Johnson labels the logical-positivism approach the "literal-truth paradigm": the idea that "[t]he human conceptual system is

155. Aristotle, Prior Analytics and Poetics, in The Basic Works of ARISTotle 1459a (R. McKcon ed., 1941).

156. Id. at 1459. For a discussion of Aristotle's view, see EILEEN C. WAY, KNOWLEdGe REPRESENTATION AND METAPHOR 3 (1991).

157. See text accompanying note 153. Locke's use of a metaphor to attack metaphors is amusing. Whether this was intentionally or accidentally ironic is lost to history.

158. F.C.T. Moore, On Taking Metaphor Literally, in Metaphor, Problems and Perspectives 1, 1-5 (David S. Miall ed., 1982).

159. See WAY, supra note 156, at 3-5.

160. Philosophical Perspectives on Metaphor 16-18, 145 (Mark Johnson ed., 1981) [hereinafter Philosophical Perspectives].

161. See id. at 16.

162. As noted in Philosophical Perspectives,

[a] though positivism is officially dead, its influence is still very much with us, and is one of the chief obstacles to an adequate understanding of metaphor. With a few important exceptions... twentieth-century Anglo-American thinking about metaphor has bcen emasculated, narrowed, and inhibited by logical positivist views of language and is therefore Id. at 16 . either hostile or patronizing toward figurative expression. 
essentially literal." ${ }^{\prime 63}$ The paradigm suggests that appeals to figurative language in philosophical discussion are wrong or inappropriate, since on this view the literal is the basis of human thinking.

However, the literal-truth paradigm increasingly has come under attack. This challenge can be traced back as far as a fundamental, but initially ignored, book by I.A. Richards. ${ }^{164}$ In The Philosophy of Rhetoric, ${ }^{165}$ Richards presented a number of ideas that have become fundamental to our current model of metaphor. First, he insisted that metaphors are not merely linguistic devices, but are in fact cognitive constructs:

The traditional theory... made metaphor seem to be a verbal matter, a shifting and displacement of words, whereas fundamentally it is a borrowing between and intercourse of thoughts, a transaction between contexts. Thought is metaphoric ... and the metaphors of language derive therefrom. ${ }^{166}$

The "literal-truth" view held that thought was literal and that metaphors were figurative linguistic devices that our literal-cognitive system generated. Richards stood this order on its head: according to him, the cognitive system was in part metaphoric, and figurative language was a reflection of our metaphoric cognitive system.

As a corollary, Richards suggested that metaphors were not superficial flourishes with which we might dispense. Even at the level of the merely linguistic, he suggested that metaphor was fundamental and ubiquitous. It is, he said, "the omnipresent principle of language." 167 However, despite being in metaphor's thrall, we are largely unaware of its influence. If asked whether the language of law, science, or journalism relied fundamentally on metaphor we would probably answer no.

Finally, Richards introduced a conception of metaphor that still holds great power. He said that metaphor was the interaction of "two thoughts of different things active together." 168 This idea captures the currently favored view of metaphor and even lends its name to what we now call interaction theory. Thus, Richards overturned the literal-truth conception of thinking

163. Id. at 12 .

164. Actually, it can be traced farther back than Richards. Both Kant and Nietzsche probably held views of metaphor contrary to the literal-truth paradigm. See 1NDURKHYA, supra note 127, at 7 (explaining why Kant's Critique of Pure Reason implicitly contains a version of the interaction theory of cognition and metaphor); supra note 162, at 14-16 (noting that Kant rejected the idea that metaphorical expression is reducible to literal concepts since metaphorical expression was an aspect of the irreducible capacity for ereativity, and that Nietzsche thought that metaphor was not a linguistic entity but a process by which we experience the world). However, these ideas of Kant and Nietzsche were never taken up by the philosophers of the day, and it was not until late in the twentieth century that ideas like these came to be acceptable within mainstream philosophical thought.

165. RICHARDS, supra note 124.

166. Id. at 94 .

167. Id. at 92 .

168. Id. at 93 . 


\section{and especially metaphor, and provided the basis for the modern under- standing of metaphorical inference. ${ }^{169}$}

\section{B. Cognitive Metaphors}

This brings us to the interaction theory of cognitive metaphors. There are, of course, many different ways of thinking about metaphor: its literary usage, its social function, its philosophical basis, ${ }^{170}$ its psychologicalmotivational force, or its comprehension by people. ${ }^{171}$ In this section, I look to interaction theory, which discusses the role that metaphor plays in structuring the way we think. ${ }^{172}$ Other major approaches to metaphor exist, such as the emotive or tension theories, ${ }^{173}$ anomaly theories, ${ }^{174}$ and the

169. Max Black adopted Richards's approach and beeame the main proponent of the theory. See Max Black, Models and Metaphors: Studies in Language and Philosophy (1962). However, it was Richards who first challenged the literal-truth conception as it applied to metaphor, and paved the way for our current understanding of metaphor.

170. See Davidson, infra note 177; Ross, infra note 177.

171. See Allan Paivio \& Mary Walsh, Psychological Processes in Metaphor Comprehension and Memory, in MetAPHOR AND ThOught 307, 308-09 (Andrew Ortony ed., 2d ed. 1993).

172. This is now a typical approach. See INDURKHYA, supra note 127; WAY, supra note 156; see also from a Metaphorical Point of View: A Multidisciplinary approach to the Cognitive Content of Metaphor (Zdravko Radman ed., 1995); Metaphor, Problems and Perspectives, supra note 158; METAPHOR AND THOUGHT, supra note 171. Contrast this with the literaryphilosophical approach of Scott Brewer, Figuring the Law: Holism and Tropological Inference in Legal Interpretation, 97 YALE L.J. 823 (1988) (suggesting that metaphor in law operates by a process of "tropological inference").

173. Consistent with the "literal-truth paradigm," emotive and tension theories posit that metaphors are deviant uses of literal language. The emotive theory is distinguished from the literaltruth paradigm and tcnsion theories by its adherence to the notion that metaphors play no role in our thinking and merely "cxcite the emotions." The tension theory holds that metaphors are only interesting in that they force the hearer to try to resolve the dissonance generated between the target and source: "Juliet is not the sun, so in what respect might she be like the sun?" Both theories suggest that metaphors are purely aesthetic, and exist only for the pleasure of the person making or hearing the metaphor. Metaphor plays no other role; it has no cognitive significance apart from the need to resolve the ambiguity inherent in the metaphor. As critics have noted, neither theory explains satisfactorily why metaphors should be used at all. See WAY, supra note 156, at 30-33, 41-46.

174. See, e.g., Monroe C. Beardsley, The Metaphorical Twist, in Philosophical Perspectives, supra note 160, at 105 (providing a good example of an anomaly theory approach to metaphor). Anomaly theories are closely related to emotive and tension theories. They rely on the idea that a metaphor is a semantic category mistake: to say that "men are wolves" is to violate the established categories we have for men and wolves, therefore forcing us to look for a secondary meaning. How we resolve these meanings differs depending on the theorist. Some anomaly theorists grant some importance to metaphor as part of our cognitive system. See, e.g., Andrew Ortony, Beyond Literal Similarity, 86 PSYCHOL. Rev. 161 (1979). Howcver, these theorists rely on either the substitution or interactionist approaches to flesh out the role in the cognitive system. These theories are not useful in examining the role that metaphor plays in legal thinking. Furthermore, anomaly theories have other significant problems that militate against their adoption. For example, reliance on semantic category mistakes fails to account for metaphors where both literal and metaphorical interpretations are possible at once, as in the case of all puns; expressions like "the rain dampened the festivities" or "the old rock is getting brittle" when remarking on a geology professor. See Michael J. Reddy, The Conduit Metaphor: A Case of Frame Conflict in our Language About Language, in METAPHOR AND THOUGHT, supra note 171, at 164. Similar observations can be made about extended figurative readings of various texts, such as Miller's The Crucible (an attack on McCarthyism), Carroll's Alice in Wonderland (a 


\section{substitution ${ }^{175}$ and comparison theories ${ }^{176}$ of metaphor. However, these all have extensive limitations that render them implausible as theories of}

parody of philosophy of languagc), Orwell's Animal Farm (an attack on communism), and The Wizard of $\mathrm{O}_{z}$ (an attack on the abandonment of the Gold Standard in the United States). See generally INDURKHYA, supra note 127, at 1. For a longer analysis, see WAY, supra note 156, at 30-33, 41-46.

175. Richards, as did many theorists of his age, adopted the substitution theory when he said that metaphor was "a sort of happy extra trick with words ... a grace or ornament or added power of language, not its constitutive form." See RICHARDS, supra note 124, at 90 . The substitution theory holds that with all metaphors, a literal expression can be substituted in place of the metaphorical expression. This can be seen as directly stemming from the "literal truth" view of language. In essence, the approach assumcs the Aristotelian view that a metaphor takes a name that properly belongs to something else.

There are significant problems with the substitution theory. First, if one accepts the theory, there is the qucstion of why metaphor exists at all. See WAY, supra note 156, at 33; M. Soskice \& R. Harré, Metaphor in Science, in From a Metaphorical Point of View: a Multidisciplinary Approach to the Cognitive Content of Metaphor 290 (Zdravko Radman ed., 1995). If one can say everything literally, why use such a roundabout, deviant, nonproper metaphorical form? Substitution theory's answer, like that of tension and emotive theories, relies on some aesthetically pleasing aspect of metaphor. As Blaek scathingly says:

The reader is taken to enjoy problem-solving - or to delight in the author's skill at halfconcealing, half-revealing his meaning. Or metaphors provide a shock of "agreeable surprise" and so on. The principle behind these "explanations" seems to be: When in doubt about some peculiarity of language, attribute its existence to the pleasure it gives a reader. A principle that has the merit of working well in default of any evidence.

BLACK, supra note 169 , at 34 . The second problem is that of the cognitive content of metaphor. Substitution theory grants no cognitive content to a metaphor outside its literal meaning. But this does not accord with our scnse, when reading literature, poetry, or even legal texts, that a well-crafted metaphor carries with it something more than its simple litcral meaning. "Juliet is the sun" not only carries the meaning that she brings light to Romeo's life, but also that she is constant, prcsent in his life each day, that her absence turns his world to darkness, that she provides the basis for life, and so forth. (On multiple interpretations of this metaphor, see John R. Searle, Metaphor, in METAPHOR AND Thought, supra note 171, at 96: "Cavell (1976, pp. 78-9) gives as part of its explanation that Romeo means that his day begins with Juliet. Now, apart from the special context of the play, that reading would never occur to me. I would look for other properties of the sun to [substitute].") Related to this concern is the practical difficulty of coming up with a ready literal expression for many metaphors. What literal expression adequately captures the meaning of: "A stubborn and unconquerable flame Creeps in his veins and drinks the streams of life"? RICHARDS, supra note 124, at 102. Or even the simpler expression that a "boy in his fiery youth stands on the giddy brink of life"? Finally, there is difficulty of the truth-literalness of the substitution theory. If all metaphors merely substitute for literal expressions then we should see some evidence that literal language is the predominant method of cognition. However, little evidence points in this direction. Reaction time studies have shown that processing metaphorical expressions takes no more time than processing literal expressions, implying that literal thinking is not necessarily the basic mechanism of thought. See Sam Glucksberg \& Boaz Keysar, Understanding Metaphorical Comparisons: Beyond Similarity, 97 PsYCHOL. Rev. 3 (1990); Sam Glucksberg et al., On Understanding Nonliteral Speech: Can People Ignore Metaphors?, $21 \mathrm{~J}$. Verbal Learning \& Verbal Behav. 85 (1982); Boaz Keysar, On the Functional Equivalence of Literal and Metaphorical Interpretations in Discourse, 28 J. MemORY \& LANGUAGE 375 (1989).

176. Comparison theory considers metaphor to be a type of condensed literal comparison or simile. So when we say that "Juliet is the sun," we know that she is not actually the sun. We are stating, elliptically, that "Juliet is like the sun." A metaphor thus becomes a condensed or elliptical simile: we merely omit "like" or "as" when making the comparison. The major benefit this has over substitution theory is that it recognizes that metaphors compare two things for similarity, rather than substituting one tcrm or expression for another. It thus captures some of the flexibility inherent in metaphorical language: for Romeo, Juliet is similar to the sun in a number of ways. However, just like the substitution theory, the comparison view holds that there is somc literal equivalent possible for each 
metaphor generally, ${ }^{177}$ and make them specifically unsuitable for application to law.

\section{Interaction Theory of Metaphor}

To understand interaction theory, we first need to consider some initial technical terminology. ${ }^{178}$ First, we use the terms "target" and "source" to refer to the "two halves of metaphor."179 In any given metaphor, the target is the principal subject. The source is the domain from which the salient features are drawn and then attributed to the target. So, in the simple metaphor "lawyers are pigs," "lawyers" is the target and "pigs" is the source. The source imports a host of features associated with "pigs" without seeking to draw an identity relation between lawyers and pigs. The associations here might include "has rapacious appetite," "has nondiscriminating taste," "eats at the trough," "grows fat," "fails to do any work," and even perhaps "has an absence of personal hygiene." However,

metaphor that exactly captures the sense of the metaphor. Searle dismantles this approach by demonstrating its inapplicability to extended metaphors such as those we find in poetry. See Searle, supra note 175, at 87-89. The second problem for the comparison theory is caused by its reliance on a metric of similarity. Similarity is a symmetrieal relation, and to say that $X$ is similar to $Y$, is to say that $Y$ is similar to $X$. Hence, on the comparison thesis, to say that "Juliet is the sun" is to say that "Juliet is like the sun" and therefore also to say "The sun is like Juliet." Though we might agree with the former simile, few would subscribe to the latter. The comparison theory suffers from a seeond problem with similarity: the "relevant attribute choice" issue. To say that something is "like" another thing is empty, as two things are similar in an infinite number of ways. See Nelson Goodman, Seven Strictures on Similarity, in Problems and Projects 437-48 (1972); Larry Alexander, Bad Beginnings, 145 U. PA. L. Rev. 57 (1996); Scott Brewer, Exemplary Reasoning: Semantics, Pragmatics, and the Rational Force of Legal Argument by Analogy, 109 Harv. L. Rev. 925 (1996); Searle, supra note 175. From this infinity of possible similar features, which is the appropriate attribute to choose in intcrpreting a metaphor as an elliptical simile? The final problem with the comparison theory revolves around what has been called the "most interesting of metaphors," those that create similarity. Indurkhya demonstrates, through a series of examples, that metaphors do not rely solely on existing similarity relations, but can create previously unthinkable relations. INDURKHYA, supra note 127, at 1-3, 8-9, 271 79. In those situations therc are no literal equivalents that can be used for the purpose of the comparison. Comparison theorists have a hard time resolving these difficulties.

177. For sophisticated defenses of this position, see Eva F. Kittay, Metaphor: Its Cognitive Force and linguistic Structure (1987); Don Ross, Metaphor, Meaning, and Cognition (1993); D. Davidson, What Metaphors Mean, 5 CRITICAL INQuIRY 31 (1981); E.F. Kittay, Metaphor as Rearranging in the Furniture of the Mind: A Reply to Donald Davidson's "What Metaphors Mean," in From a Metaphorical Point of View: a Multidisciplinary Approach to the Cognitive CONTENT OF METAPHOR 55 (Zdravko Radman ed., 1995). These elaborate defenses are not relevant to the argument here. There is a variant of the comparison theory called the analogy theory, which, though interesting, is not held by many. For an exposition and dismantling of it, see WAY, supra note 156, at 35,39 .

I78. The same terminology is used for analogy theory, cementing the similarity between the two processes of reasoning. See Hunter, supra note 18, at 1206-11.

179. See RICHARDS, supra note 124. Richards, as do other metaphor theorists, actually uses "tenor" and "vehicle" for "target" and "source," respectively. See, e.g., id. at 100. I prefer the use of "target" and "source," terms commonly used in analogy research. See, e.g., INDURKHYA, supra note 127, at 14-17; LAKOFF \& TURNER, supra note 151, at 38-40. Use of the same terms in metaphor and analogy highlights the connection between the two fields and avoids the confusion that results from use of multiple nomenclatures. 
not all metaphors are as simple as this example, and many involve hidden targets, secondary sources, and many more complex elements that need not detain us.

It is fundamental to interaction theory that "what is expressed by metaphor can be expressed in no other way. The combination effected by the metaphor results in a new and unique agent of meaning." 180 In interaction theory, the source and target interact: the ideas, the "associated commonplaces," and the implications of the source domain are projected onto the target, and vice versa. ${ }^{181}$ Max Black calls these features the "implication-complex" to emphasize that they are a set of features that affect the interpretation of the target. ${ }^{182} \mathrm{He}$ explains this by suggesting that the implication-complex must be a system rather than an individual thing. For instance, "man is a wolf" is not about the wolf qua thing, but rather the system of relationships that are signaled by the presence of the word "wolf." When we hear the metaphor, we are influenced by all the commonplaces of the source system. The source system selects and emphasizes some features of the target system while suppressing others. ${ }^{183}$ So we interpret "wolf" on the basis of our knowledge and "associated commonplaces" about wolves. When presented with the metaphor, we are immediately assailed with recollections about wolves being "ferocious, territorial, and possessive." The source selects and emphasizes those "wolf-like" aspects that are already present in our view of man. ${ }^{184}$

Black's interaction theory ${ }^{185}$ articulates two fundamental features of metaphor that are not explained by other theories: the effect of the source domain's implication complex on the target domain, and the concept that the metaphor creates something new in cognitive processes and is not

180. Soskice \& Harré, Metaphor in Science, supra note 175, at 291.

181. I stress here the effect that the source has upon the target. Black's account holds that the relationship also works in the other way: that the target also influences the source. On this interpretation, upon hearing the "man is a wolf" metaphor, our view of a wolf is also changed to adopt man-like featurcs. See BLACK, supra note 169, at 44 ("If to call man a wolf is to put him in a special light, we must not forget that the metaphor makes the wolf seem more human than he otherwise would.").

182. Max Black, More About Metaphor, in Metaphor and Thought 19, 27-28 (Andrew Ortony ed., 2d ed. 1993).

183. Black later retracted his suggestion that the target is a system and suggested that it must be a single entity. $l d$. at 27 . Indurkhya rescued the target system as a valuable concept by suggesting that they may work at different levels. INDURKHYA, supra note 127 , at 73 . He also neatly showed that the interpretation of metaphors relies on the target having an indcpendent system of its own; otherwise it would be impossible for there to be any constraint in the interpretation of metaphor. Id. at 73, 93-111. I shall thus assume that there is a system for both the source and target.

184. Note that the associated commonplaces may be wrong; studies of wolves show them to be anything but inherently ferocious or possessive. But as long as the commonplaces are commonly held, their accuracy is irrelevant.

185. As modified by various eommentators, most notably INDURKHYA, supra note 127 . 
merely a transmission or reflection of some other term. ${ }^{186}$ However, he fails to explain why we choose the metaphors we do. The most prominent modern metaphor theorists, George Lakoff and his colleagues, Mark Johnson and Mark Turner, fill this gap.

\section{Lakoff and Metaphor}

Lakoff and his colleagues have amassed a large body of empirical data that supports interaction theory. ${ }^{187}$ Their influential approach has a number of distinguishing features, but it is most notable for its assertion that our everyday concepts are structured and molded by a series of cognitive metaphors that all human beings share. Their cognitive metaphors are not linguistic metaphors like Shakespeare's "Juliet is the sun" or Justice Cardozo's "trackless ocean of law." 188 Instead, they look to metaphorical concepts that organize our thinking. ${ }^{189}$ These metaphors break down into various types, most of which stem from our physical experiences as humans in the world. These conceptual cognitive metaphors are reflected in linguistic utterances; that is, what we would normally think of as a "metaphor."

Lakoff suggests that we can excavate our underlying conceptual metaphorical structures by a close examination of our use of language: "Since metaphorical expressions in our language are tied to metaphorical concepts in a systematic way, we can use metaphorical linguistic expressions to study the nature of metaphorical concepts and to gain an understanding of the metaphorical nature of our activities." 190 An example may make the approach clearer. According to Lakoff, we all hold a communal, cognitive conceptual metaphor that ARGUMENT IS WAR. We see this metaphorical structure reflected in language thus:

- Your claims are INDEFENSIBLE.

- He ATTACKED EVERY WEAK POINT in my argument.

186. But cf. supra notes 173-176 and accompanying text (describing other metaphor theories that reject the cognitive creation component of interaction theory).

187. See Johnson, supra note 121; George Lakoff, Women, Fire and Dangerous Things: What Categories Reveal About the Mind (1987); George Lakoff \& Mark Johnson, Metaphors We Live By (1980); Lakoff \& Turner, supra note 151; Philosophical Perspectives, supra note 160; M. Turner, Categories and Analogies, in Analogical Reasoning: PersPectives of Artificial 1ntelligence, Cognitive Science, and Philosophy 3 (David H. Helman ed., 1988). In addressing this approach to interactionist theory of metaphor, 1 will hereafter simply refer to "Lakoff" but this should be taken to include his colleagues who advance similar approaches to metaphor and the embodiness of cognitive processes. Although Lakoff disputes that his theory is an interaction theory, see LAKOFF \& TURNER, supra note 151, at 131-33, his concern seems to have more to do with his unhappiness with the symmetrical requirement in Black's view of metaphor. See INDURKHYA, supra note 127 , at 81 . For our purposes, the Lakofflan view fits within the interaction theory.

188. See supra note 20.

189. LAKOFF \& JOHNSON, supra note 187, at 6. ("Therefore, whenever... we speak of metaphors ... it should be understood that metaphor means metaphorical concept.”).

190. Id. at 7. 
-His criticisms were RIGHT ON TARGET.

-I DEMOLISHED his argument.

- I've never WON an argument with him.

- If you use that STRATEGY, he'Il WIPE YOU OUT.

- He SHOT DOWN all of my arguments. ${ }^{191}$

Lakoff is not saying that we actually view arguments exactly as war. Rather, he suggests that features from the source domain (war) are mapped onto the target (argument). Thus, we cognitively structure our perception of arguments in terms that adopt elements of war, and our use of language reflects this structure.

We see the same LEGAL ARGUMENT IS WAR metaphor in the construction of the common law trial system. Apart from the historical significance of the violence attendant on legal process ${ }^{192}$ and the idea of medieval "trial by battle," 193 which was a possible mode of trial in some common law jurisdictions until $1819,{ }^{194}$ there are the facts that the system is ADVERSARIAL, that attorneys go off to DO BATTLE or GO INTO COMBAT with the OTHER SIDE, that in the English system Queen's Counsel LEAD junior barristers, that law firms have WAR ROOMS for big pieces of litigation, and that one party WINS the case.

Lakoff's great advance was to demonstrate through a large body of empirical linguistic evidence that linguistic metaphors reflect our underlying cognitive system. He showed that the utterer of a linguistic metaphor was constrained in the content of the metaphor by commonly held coguitive conceptual metaphors. Poetry provides a compelling example. At first blush, we might consider that poets are free to invent any metaphor they choose. However, Lakoff and Turner explain:

[W] make a distinction between basic conceptual metaphors, which are cognitive in nature, and particular linguistic expressions of these conceptual metaphors. Thus, though a particular poetic passage may give a unique linguistic expression of a basic metaphor, the conceptual metaphor underlying it may nonetheless be extremely common. ${ }^{195}$

Metaphors, therefore, are not just linguistic devices. They actually form a core part of our cognitive conceptual system. Conceptual metaphors form

191. Id. at 4 .

192. See J.H. Baker, An Introduction to English Legal History 413 (2d ed. 1979) ( "[The] principal object [of the appeal of felony in Norman and Angevin times] was retribution, the invaluable satisfaction to be gained from annihilating an aggressor by legal process.").

193. Id. at 414 ("The proper mode of trial was not the jury ... but BATTLE; and the delays and evasions which accompanied JUDICIAL COMBAT made the proceedings cumbersome....") (emphasis added).

194. G. Cross \& G.D.G. Hall, Radcliffe and Cross on the English Legal System 19 n.2 (4th ed. 1964).

195. LAKOFF \& TURNER, supra note I5I, at 50. 
an important part of any model of legal reasoning and will be particularly important to my model of cyberspace regulation. ${ }^{196}$

Lakoff and others make the vital point that all humans share a system of conceptual metaphors, even if the individual linguistic utterances may be unique. ${ }^{197}$ This requirement of sharing imposes a great constraint on the types of reasoning we may undertake. We readily understand the allusions inherent in Emily Dickinson's poem, "Because I Could Not Stop for Death," 198 which presents life as travel, ${ }^{199}$ since we share the metaphorical concept that LIFE IS A JOURNEY. We would have a harder time understanding a poem structured around a LIFE IS THE SKY metaphor, since this is not a metaphor that we hold as a shared construct.

This general observation about the importance of the construction of conceptual metaphors leads to a more specific concept, which Lakoff and Turner call "structural mapping." 200 They discuss a number of poems, including "Because I Could Not Stop for Death." In comprehending these poems, they note that we are using the commonly held LIFE IS A JOURNEY metaphor. The question is, then, what "use" means. They suggest that the answer involves identifying the structural elements of the metaphor and then mapping the source elements (our knowledge of journeys) onto the target (the poem about life). For example, all journcys have welldifferentiated structural elements (the beginning, middle and end), all journeys have travelers, there are impediments on the road of life, and so on. These associations with journeys are then applied to the target.

When we map the source domain onto the target domain, we generate new thoughts about the way in which the target works. ${ }^{201}$ The process of mapping leads to the identification of new features in the metaphor that are brought over when the metaphor is made, as well as additional inferences. For example, in applying the LIFE IS A JOURNEY metaphor, we may think of

196. Infra Part 111 .

197. LAKOFF \& TURNER, supra note 15I, at 50.

198. Emily Dickinson, Because I Could Not Stop for Death, in The Complete Poems of Emily Dickinson 350 (Thomas H. Johnson ed., 1976).

199. See LAKOFF \& TURNER, supra note I51, at I-56, 60-63.

200. LAKOFF \& JOHNSON, supra note 187, at 10.

201. LAKOFF \& TURNER, supra note 151, at 62. Lakoff and Turner noted:

Part of the power of [the LIFE IS A JOURNEY] metaphor is its ability to create structure in our understanding of life. Life, after all, need not be viewed as a journey. It need not be viewed as having a path, or destinations, or impediments to travel, or vehicles. That structuring of our understanding of life comes from the structure of our knowledge about journeys. When we reason about life in terms of destinations, forks in the road, roadblocks, guides, and so on, we are importing patterns of inference from the domain of journeys to the domain of life. For example, we can infer from the facts that someone is spinning his wheels that he is not getting anywhere and will not reach his destination. We can infer from the fact that someone has hit a roadblock that if he is to continue on he must deal with it in some way: rcmove it, get over it, get around it, or find another route. Much of our reasoning about life involves inferences of this sort. Thus, the power to reason about so abstract an idea as life comes very largely through metaphor. 
a person as "spinning her wheels" or "facing a roadblock." These implications are generated or "entailed" by adoption of the metaphor, and Lakoff terms them the "metaphorical entailment." 202 The next Part of this Article demonstrates that the same thing occurs in cyberspace regulation. The CYBERSPACE AS PLACE metaphor leads to a series of metaphorical entailments: cyberspace is like the physical world and can be zoned, trespassed upon, interfered with, and divided up into a series of small landholdings that are just like property holdings in the physical world.

III

\section{Cyberspace as Legal Place}

With the Web becoming an important mechanism for commerce... companies are racing to stake out their place in cyberspace. ${ }^{203}$

The Lakoffian view of metaphor explains why the language we use to describe our experience of the Web is a reflection of an underlying conceptual metaphor. The relevant metaphor in Internet regulation is CYBERSPACE AS PLACE. Adopting the metaphor means that we understand the medium of Internet communication as having certain spatial characteristics from our physical world experience. Telling in this regard are the references that have been variously used to describe the "consensual hallucination"204 of life on the Internet. A number of simple examples were given in Part I: web, net, sites, access, trespass, navigating, visiting, transport, and so forth. ${ }^{205}$

A short while ago, Mark Lemley memorably congratulated James Boyle on managing to write a whole book on the law of information without mentioning any of the usual tropes ${ }^{206}$ "information superhighway,"207 "Infobahn,"208 "metaverse," 209 or the more prosaic "National Information

202. LAKOFF \& JOHNSON, supra note 187, at 16-20.

203. Brookfield Communications, Inc. v. Wcst Coast Entm't Corp., 174 F.3d 1036, 1044 (9th Cir. 1999).

204. William Gibson, Neuromancer 51 (1984) (calling cyberspace "[a] consensual hallucination experienced daily by billions of legitimate opcrators").

205. See supra Part 1.B.

206. See Mark A. Lemley, Romantic Authorship and the Rhetoric of Property, 75 TEx. L. Rev. 873, 873-74 (1997) (revicwing James Boyle, Shamans, Software, and Spleens: Law and the CONSTRUCTION OF THE INFORMATION SOCIETY (1996)).

207. Id. at $873 \mathrm{n} .2$.

208. Id. at 873 n.6. This term was "popularized by Wired magazine in 1994 as an alternative to the then-ubiquitous "Information Superhighway." Id. (citing John Perry Barlow, Jackboots on the Infobahn, WIRED, Apr. 1994, at 40).

209. Lemley, supra note 206, at 873 n.8. This term, which never gained currency, comes from Neal Stephenson, SNow Crash 22 (1992). Stephenson's "mctaverse" was a virtual world laid out in familiar spatial terms, with a main strcet to the city, houscs and commercial "buildings," nightclubs and bars, and transportation facilities. $I d$. 
Infrastructure." ${ }^{10}$ Of the term "cyberspace," Lemley noted that all law review articles attribute its coining to William Gibson's wildly successful novel, Neuromancer. ${ }^{211}$ Interestingly, however, "cyberspace" was not the term used most often by Gibson. He usually referred to cyberspace as "the matrix." 212 It is revealing of our understanding of the Web, that the term "cyberspace," rather than "matrix" or any other expression, has triumphed. ${ }^{213}$ "Cyberspace" is a more expansive description of all of the multifarious interactions that occur via these new communications mechanisms. I think this is due to the CYBERSPACE AS PLACE metaphor, although this is impossible to prove. The many linguistic usages mentioned earlier point the same way. ${ }^{214}$

The CYBERSPACE AS PLACE metaphor is also clearly evident in legal material. There are now numerous cases that have decided issues relating to the Internet and the Web. In keeping with the observation of the use of spatial terms in lay speech, ${ }^{215}$ we find a proliferation of references in legal cases. Thus, in deciding whether a company was entitled to adopt its competitor's registered trademark in its site's metatags, ${ }^{216}$ the court in

210. Lemley, supra note 206, at 873 n.3.

211. Id. at 873 n.4. Lemley mistakenly suggests that Gibson coined the term in Neuromancer. GIBSON, supra note 204. This common misconception seems to stem from relying on either EDWARD A. Cavazos \& Gavino Morin, Cyberspace and the Law: Your Rights and Duties in the ONLINE WORLD I (1994), or RHEINGOLD, supra note 6, at 5. The earliest referenee of the term was actually in William Gibson, Burning Chrome, OMNI, July 1982, at 72, reprinted in WiLliam Gibson, Burning Chrome (1986).

212. Gibson's term was appropriated in the movie, THE MATRIX (Warner Bros. 2000), by the Brothers Wachoswski, who used it somewhat differently. In the film, "The Matrix" was Plato's Cave Illusion of Reality, a computer-simulated eonstruct generated by evil artificial intelligences. In Neuromancer, the matrix was synonymous with cyberspace, not a simulation of reality. See GiBson, supra note 204.

213. As early as 1995, the MIT cybertheorist and Dean of the Architeeture School, William J. Mitchell, identified the term as the dominant expression:

This word ["cyberspace"] does not have a respectable technical pedigree, but was introduced by William Gibson in his 1984 novel Neuromancer. Many old computer hands detest it for the conceptual vulgarities that it has come to connote. But it has won out against all the plausible alternatives and has succeeded in taking possession of its semantie niche, so 1 shall use it.

MiTCHELL, supra note 1 , at 181 n.34.

214. See supra Part 1I.B. Other linguistic evidence of the inereased acceptance of the CYBERSPACE AS PLACE metaphor seems to exist in the subtle changes of terminology that have occurred as our understanding of eyberspaee has changed. At first, web material usually existed as "homepages." That term made sense when the web was primarily a publishing mechanism, see TIM BERNERS-LEE \& MARK FisCheTtI, WEAVING THE WEB (2000), but even when the term "homepage" was common, the placelike character was still evident. See MiTCHELl, supra note I, at 118, 124 ("[Your] homepage is your castle."). "Homepage" seems to have been supplanted over the last few years by "website," in part probably because many sites are commercial and no longer "home"-like. I suspect that this is also because the more elaborate sites no longer give the impression of being pages at all, but rather abstract places that one visits and interacts with rather than reads. This is, of course, consistent with the CYBERSPACE AS PLACE metaphor.

215. See supra Part 1.B.

216. As the court explains: 
Brookfield v. West Coast compared the metatag to a billboard, deceptively advertising the competitor's store as its own. ${ }^{217} \mathrm{~A}$ series of cases concerned with the liability of bulletin board systems ("BBSs") and ISPs led courts to search for physical-world analogies. ISPs were analogized to telecommunications carriers, ${ }^{218}$ newsprint publishers, ${ }^{219}$ landlords of dance halls playing music illegally, ${ }^{220}$ landlords for the operators of infringing record swapmeets, ${ }^{221}$ and illegal radio stations. ${ }^{222}$ All of these examples take the physical charactcristics-and legal consequences-of the physical world and map them onto the abstract virtual world.

This process of mapping the physical onto the virtual is pervasive in legal aeademic discourse, judicial pronouncements, and legislative enactments. Lakoff explains that we cannot avoid seeing abstract concepts in physical terms such as this. ${ }^{223}$ We should then expect that lawyers would adopt the CYBERSPACE AS PLACE metaphor. However, wc need to recognize what the adoption of the metaphor entails. As Lakoff and Black have shown, the metaphor carries with it the implication complex that constrains the sorts of outcomes we can expect. ${ }^{224}$ In Part IV I will argue that adoption

Metatags are HTML code intended to describe the contents of the website... The more often a term appears in the metatags and in the text of the web page, the more likely it is that the web page will be 'hit' in a search for that keyword, and the higher on the list of 'hits' the web page will appear.

Brookfield Communications, lnc. v. West Coast Entm't Corp., 174 F.3d 1036, 1045 (9th Cir. 1999).

217. Id. at 1064. The court reasons:

Using another's trademark in one's metatags is much like posting a sign with another's trademark in front of one's store. Suppose West Coast's competitor (let's call it "Blockbuster") puts up a billboard on a highway reading-_-"West Coast Video: 2 miles ahead at Exit 7"-where West Coast is really located at Exit 8 but Blockbuster is located at Exit 7. Customers looking for West Coast's store will pull off at Exit 7 and drive around looking for it. Unable to locate West Coast, but seeing the Blockbuster store right by the highway entrance, they may simply rent there.

Id.

218. See Religious Tech. Ctr. v. Netcom On-Line Communication Serv., Inc., 907 F. Supp. $136 \mathrm{I}$ (N.D. Cal. 1995).

219. See Cubby, Inc. v. CompuServe, Inc., 776 F. Supp. 135 (S.D.N.Y. 1991). By contrast, a New York state court judge found that Prodigy was a publisher because it held itself out to be controlling the content of its services and because it used software to automatieally presereen messages that were offensive or in bad taste. Stratton Oakmont, Inc. v. Prodigy Servs. Co., 1995 WL 323710, at *I (N.Y. Sup. Ct. May 24, 1995).

220. See Fonovisa, Inc. v. Cherry Auction, Inc., 847 F. Supp. 1492, 1496 (E.D. Cal. 1994); see also Kelly Tickle, Comment, The Vicarious Liability of Electronic Bulletin Board Operators for the Copyright Infringement Occurring on Their Bulletin Boards, 80 lowA L. REv. 391, 415 (1995) (arguing that BBS operators "lease cyberspace" and should thus be treated like landlords, who are not liable for infringement that occurs on their premises).

221. See Religious Tech. Ctr, 907 F. Supp. at 1375. ("Providing a service that allows for the automatic distribution of all Usenet postings, infringing and noninfringing, goes well beyond renting a premises to an infringer.... It is more akin to the radio stations that were found liable for rebroadcasting an infringing broadcast.")

222. See Select Theatres Corp. v. Ronzoni Macaroni Corp., 59 U.S.P.Q. 288, 291 (S.D.N.Y.1943).

223. Supra Part 11.B.2.

224. Supra Part II.B. 
and use of the CYBERSPACE AS PLACE metaphor within law leads to a view of cyberspace as land that may be fenced off and privatized. ${ }^{225}$

As a foundation, this Part details the application of the CYBERSPACE AS PLACE metaphor within legal discourse. It examines the numerous examples of the metaphor within law, including criminal law, torts, and constitutional law, among others. It shows how judges, legislators, and commentators in each legal area have (often unconsciously) adopted the metaphor. Contrary to those who have argued that cyberspace is not a place for the purposes of legal analysis, ${ }^{226}$ this Part shows that spatial assumptions pervade the law of cyberspace.

\section{A. Crime Online}

A great many criminal laws involve computers or the Internet. ${ }^{227}$ These laws include federal, ${ }^{228}$ state, ${ }^{229}$ and international legislation ${ }^{230}$ specifically targeted at the computer as the subject of crimes such as computer trespass $^{231}$ or data misuse. ${ }^{232}$ They also encompass the computer as the object or tool of other more traditional crimes, such as fraud ${ }^{233}$ or forgery. ${ }^{234}$

Laws against computer crime represent one of the earliest areas where the conception of a computer network as a place emerged. The most obvious example, the Computer Fraud and Abuse Act of 1986 ("CFAA"), ${ }^{235}$ relied on the spatial characteristics of a network long before the Internet

225. Infra Part IV.A.

226. See supra Part 1.A.

227. See Neal K. Katyal, Criminal Law in Cyberspace, 149 U. PA. L. Rev. 1003 (2001).

228. See 18 U.S.C. $\S \S 1030,2510-2521,2701-2710$ (1994); 15 U.S.C. $\S 77$ (a)-(aa) (2000); see also Rudolph J. Peritz, Computer Data and Reliability: A Call for Authentication of Business Records Under the Federal Rules of Evidence, 80 Nw. U. L. REv. 956, 991 (1986) (mentioning the Computer Fraud and Abuse Act, 18 U.S.C. $\$ 1030$ (Supp. 1985)).

229. See, e.g., Am. Libraries Ass'n v. Pataki, 969 F. Supp. I60, 182 (S.D.N.Y. 1997) (referring to Ga. Code AnN. § I6-19-93.I (1996), OkLa. Stat. tit. 21, § 1040.76 (1996), and N.Y. Penal Law $\S$ 235.20(6)); People v. Versaggi, 83 N.Y.2d 123, 129 (1994) (outlining the New York State computerrelated offenses).

230. See, e.g., Cole Durham, The Emerging Structures of Criminal Information Law: Tracing the Contours of a New Paradigm: General Report for the AIDP Colloquium, 64 Revue InTERNATIONALE DE Droit Penal 79, 97-109 (1993) (discussing patterns of convergence in computer crime legislation with regard to unauthorized use or reproduction of computer programs, unauthorized reproduction of topography, computer forgery, and computer fraud); cf. Hon. Justice Michael Kirby, Legal Aspects of Transborder Data Flows, 11 ComPUTER/L.J. 233, 239 (1991) (mentioning the need for international legislation specially designed to cover computers).

231. See, e.g., United States v. Agnello, 163 F. Supp. 2d 140, 145 (E.D.N.Y. 2001) (mentioning adoption of computer trespass related crimes). I will discuss the crime of computer trespass in much greater detail later in this Part.

232. See Pamela Samuelson, Privacy as Intellectual Property?, 52 Stan. L. Rev. 1125, 1145 (2000) (discussing data misuse within context of personal privacy).

233. See, e.g., Am. Online, Inc. v. CN Prods., Inc., 272 B.R. 879, 880 (E.D. Va. 2002) (examining CFAA's section 1030(a)).

234. See Durham, supra note 230, at 97-109 (discussing the crimes of computer forgery and computer fraud).

235. 18 U.S.C. $\& 1030(1996)$. 
entered the minds of legislators. ${ }^{236}$ The offenses proscribed by the Act involve access to computers and the networks that comprise them. For example, section 1030(a)(5)(A)(ii) provides that whoever "intentionally accesses a protected computer without authorization, and as a result of such conduct, recklessly causes damage" above a specified value, is guilty of an offense. Other sections deal with the special cases of unauthorized access of government computcr systems, ${ }^{237}$ obtaining information from government agencies through such access, ${ }^{238}$ unauthorized access to obtain credit card information or credit reports, ${ }^{239}$ and a slew of othcr crimes stemming from the trespass. However, all offenses sharc the basic requirements of unauthorized access of the computer (to deal with outsiders hacking into a system) or accessing a computer beyond the limits of authorization (to deal with insiders who have legitimate access to the system but move beyond the scope of their authorization). ${ }^{240}$

These types of offenses are generically labeled "computer trespasses," 241 and it is not hard to understand why. The computer is "accessed" without permission, implying the illegal entry into the system. Not for nothing do we see movie depictions of hackers announcing triumphantly "l'm in" when they access a computer system. ${ }^{242}$ They may use a "backdoor" to enter the system, ${ }^{243}$ or just bypass (that is, "pass by") the security. Authorized users type a word that allows them passagc into the

236. The Internet was the network of networks that arose from ARPANet and a series of other networks, circa 1969. See Management of Internet Names and Addresses, 63 Fed. Reg. 31,741 (June I0, 1998). 1t was initially confined largely to edueational and military uses under the auspices of the National Science Foundation until 1992, when the Scientific and Advanced-Technology Act of I992, Pub. L. No. 102-476 § 4, 106 Stat. 2297, 2300 (1992), came into effect and provided for its commercial exploitation. The earliest CFAA case involving the Internet was United States v. Morris, 928 F.2d 504 (2d Cir. 1991), whieh held that the defendant's transmission of computer "worm" into the lnternet, a "group of national networks that connected university, governmental, and military computers around the country," constituted accessing a federal computer without authorization. Id. at 505 .

237. See CFAA, I8 U.S.C. \$1030(a)(1).

238. See id. $\$ 1030(\mathrm{a})(2)(\mathrm{B})$.

239. See id. \& 1030(a)(2)(A).

240. All provisions include the expression "exceeds authorized access." See, e.g., id. $\$ 1030(\mathrm{a})(1)$.

24I. See, e.g., People v. Versaggi, 83 N.Y.2d 123, 129 (1994) (noting the New York state legislation proscribing computer trespass, Penal Law $\S 156.10)$.

242. See Briggs v. State, 704 A.2d 904, 907 (Md. I998) ("The word 'hacker' has beeome synonymous with a computer criminal, and typically refers to a person who breaks into computer networks."). For examples of the use of the phrase "l'm in" by hackers in movies, see, for example, SWORDFISH (Warner Bros. 2001), SNEAKERS (Universal 1992), and WARGAMEs (MGM 1983).

243. See Simon Edwards, Know Your Enemy, 85 PC Pro (Nov. 21, 2001), available at http://www.psiborg.net/transceiver/txt/kye.html. Edwards explains the function and value of backdoors for hackers:

If an attacker is able to gain any kind of meaningful access to your system he will probably wish to return at some point. But rather than have to go through the hacking process again, which often involves the risk of being logged and caught, any hacker worth his salt will want ld. to wedge in a metaphorical doorstop, otherwise known as a backdoor. 
system, hence the name "password." Commentators sometimes bemoan the inexactness of the use of the expression "accessing" a computer:

Access is an unfortunate term applied to computers that causes considerable confusion, especially with regard to criminal law. We understand what it means to access or approach and enter a physical location, but entering a computer is downright impossible. ${ }^{244}$

Use of the expression is, however, an obvious example of linguistic usage reflecting a deeper physical computer as place metaphor. ${ }^{245}$

It is not surprising then that, when courts applied the CFAA to Internet-connected computers, the initial computer as place metaphor was supplanted by the CYBERSPACE AS PLACE metaphor. This latter metaphor has emerged as the dominant way of understanding criminal computer trespasses over networks. The network provides the means of moving around, and the servers, hosts, or websites within the network are the access points. ${ }^{246}$ So, for example, one court held that the CFAA entitled an Internet dating service to a temporary restraining order that prohibited a former programmer from accessing the dating service's website via the Internet and diverting its clients and users to a pornography site. ${ }^{247}$ One court has extended this idea. It suggested that because of the technical requirements of the Internet's fundamental transmission protocol, TCP/IP, which relays messages through many computers before they reach their final destination, the person initiating the transmission actually accesses each computer in the transmission chain. ${ }^{248}$ In both these cases, the idea of cyberspace as a place can be seen clearly. The Internet is conceived in familiar terms, just like the public roads that lead to private properties on which the defendant trespasses.

244. Donn B. Parker, Fighting Computer Crime: A New Framework for Protecting INFORMATION 82 (1998).

245. The same author betrays the physical character of the abstract space that is the computer and the network:

We APPROACH a computer at the moment that we initiate an electrical signal in a circuit, such as flipping an on-off switeh or depressing a key on a keyboard.... [W]e should abandon our use of the term access with regard to information and networks. We LOCATE information and/or OPEN information files. When we use a network, we SEND or RECE1VE MESSAGES, or monitor information that PASSES THROUGH the network. In both cases, use is a more precise-and more accurate-descriptor of our actions than access.

Id. (some emphasis in original removed; full capitals added for emphasis). All of the fully capitalized terms in this excerpt betray the concept of physical movement through space characteristic of our language usage in this area.

246. See, e.g., Am. Online, Inc. v. Nat'l Health Care Disc., 1nc., 121 F. Supp. 2d 1255, 1273 (N.D. lowa 2000) (noting that email transmissions move between systems, accessing each system on the way).

247. YourNetDating, Inc. v. Mitchell, 88 F. Supp. 2d 870 (N.D. Ill. 2000).

248. Nat'l Health Care Disc., Inc., 121 F. Supp. 2d at 1255. A colleague commented to me that this was an "insane result." lt is hard to disagree with this assessment. 
More troubling than this, the CYBERSPACE AS PLACE metaphor has led to the application of the CFAA to problematic uses of publicly accessible websites, in circumstances that are far from the original intended criminal scope of the CFAA. In a series of cases involving unsolicited bulk emails (the "spam cases") ${ }^{249}$ and companies downloading information from competitor's websites (the "website cases"), ${ }^{250}$ courts have used the CYBERSPACE AS PLACE metaphor and extended the scope of the CFAA's provision for civil actions beyond recognition. ${ }^{251}$

In the spam cases, providers of email services prevailed over spammers who harvested email addresses from them. In each case, the court had no difficulty applying laws directed at criminal actions to the civil subject matter before it. The most interesting issue was how the spammer's access was forbidden, since computer trespass requires "unauthorized access" of the computer system. One might imagine that email, even unsolicited bulk email, could not amount to an unauthorized access. Yet the courts have found that spammers lacked authorization for this type of "access" of the email system when the "Terms of Use" of the providers' systems specifically forbade access for this purpose. ${ }^{252}$

Spam is such an egregious intrusion of online space, and such a pernicious evil to Internet usage, that we should hardly be surprised that courts would extend criminal liability to this type of activity. It is hard to feel sorry for the spammers. We might hope, however, that courts would limit the CFAA to these sorts of outrageous activities. This is not so, however. In the website cases, courts have been exceedingly swift in applying criminal sanctions to practices that are competitive, but hardly criminal. In

249. Id. (holding spam on AOL's system actionable under the CFAA); Am. Online, Inc. v. GreatDeals.net, 49 F. Supp. 2d 85 I (E.D. Va. 1999) (same); Am. Online, Inc. v. IMS, 24 F. Supp. 2d 548, 550-5I (E.D. Va. 1998) (same); Am. Online, Inc. v. LCGM, Inc., 46 F. Supp. 2d 444 (E.D. Va. 1998) (holding that Internet site operators violated the CFAA when they maintained membership with $A O L$ in order to harvest email addresses of AOL's customers and then used the addresses to send bulk emails to those customers in violation of AOL's terms of service).

250. E.g., EF Cultural Travel BV v. Explorica, lnc., 274 F.3d 577 (Ist Cir. 2001) (finding that a competitor's use of a "scraper" program to glean prices from a tour company's website in order to allow systematic undercutting of those prices "exceeded authorized access" within the meaning of CFAA, 18 U.S.C. $\S \S 1030(a)(4)$, (e)(6)); Register.com, Inc. v. Verio, Inc., I26 F. Supp. 2d 238 (S.D.N.Y. 2000) (holding that extraction of data from WHOIS records is actionable under the CFAA).

25l. Section $1030(\mathrm{~g})$ provides that a civil action may be brought under some subsections of the CFAA as long as certain requirements are met:

Any person who suffers damage or loss by reason of a violation of this section may maintain a civil action against the violator to obtain compensatory damages and injunctive relief or other equitable relief.... Damages for violations involving damage as defined in subsection (a)(5)(B)(i) are limited to economic damages.... No action may be brought under this subsection for the negligent design or manufacture of computer hardware, computer software, or firmware.

CFAA, 18 U.S.C. $\$ 1030(\mathrm{~g})$.

252. See, e.g., Nat'l Health Care Disc., Inc., 121 F. Supp. 2d at 1260, 1272-73 (commenting that "[t]he 'Conditions of AOL Membcrship,' displayed on every new member's computer screen at the time of enrollment" could render defendant's actions an "unauthorized access" under the CFAA). 
Register.com, Inc. v. Verio, Inc., ${ }^{253}$ the practice involved Verio's "scraping"254 of WHOIS data from Register.com's website. 255 Register.com, like all domain name registrars, was obliged to publish the WHOIS records of the domain names that it registered. ${ }^{256}$ Register.com published its registrants' WHOIS records on its publicly accessible website. Verio, a competitor in the domain name registration and website hosting business, collected these records from Register.com for domain names that had been recently registered. ${ }^{257}$ Verio then used this information to contact the domain name registrants, offering them various website hosting services.

At no point did Verio hack into Register.com's database. Rather, it gathered all of the information from the publicly available website. The sum total of Verio's "access" of Register.com's computer system was a series of well-formed http requests ${ }^{258}$ to Register.com's web server, which Register.com had already made available to the Web at large. Moreover, the data that Register.com sent in response to these http requests was information that, under the terms of its agreement with the Internet Corporation for Assigned Names and Numbers ("ICANN"), ${ }^{259}$ it was obliged to make public. ${ }^{260}$ These facts notwithstanding, the court had no qualms about holding that Verio was guilty of a computer trespass under 18 U.S.C. $\S \S I 030(a)(2)(C)$ and $(5)(C) .{ }^{261}$ The court reasoned that Verio accessed the computer system of Register.com without authorization. Register.com maintained a "Terms of Use" policy for its website, tucked away on a separate page from the default page, which forbade Verio from using an automated search mechanism (so-called robots) to poll the Register.com WHOIS database. ${ }^{262}$ The court's analysis was straightforward: "[B]ecause Register.com objects to Verio's use of search robots they represent an

253. 126 F. Supp. 2d 238 (S.D.N.Y. 2000).

254. "Scraping" or "screen scraping" involves the exhaustive traversal and collection of all data on a site. See Julia A. Gladstone, Data Mines and Battlefields: Looking at Financial Aggregators to Understand the Legal Boundaries and Ownership Rights in the Use of Personal Data, 19 J. MARSHALL J. Computer \& INFO. L. 313 (2001).

255. Register.com, Inc., $126 \mathrm{~F}$. Supp. $2 \mathrm{~d}$ at 242 (addressing the defendant's access to the plaintiff's database that "contain[ed] the names and contact information-postal address, telephone number, electronic mail address and in some cascs facsimilc number-for customers who register domain names through the registrar").

256. Id. at 241. A WHOIS record details the name, address, and contact information of the domain name holder, as well as ccrtain technical data about the domain name. $I d$. at 242 .

257. Id. at 243.

258. See M. Sean Fosmire, Intranets and Extranet-The Extension of Web Technology to the Distribution of Private Information, $77 \mathrm{MICH}$. B.J. 412, 416 (1998) (explaining the basics of http).

259. ICANN is the body that has eventual oversight of the allocation of all domain names and $1 P$ addresses and whose terms Rcgistcr.com had to meet in order to be granted the right to register domain names. See Register.com, Inc., 126 F. Supp. 2d at 242.

260. Id. at 242-43.

261. Id. at 251-52.

262. Id. at 242 . 
unauthorizcd access to the WHOIS database." ${ }^{263}$ That is, the simple objection to access provided the basis for the liability. This was true even though Verio merely made a request on a publicly accessible database. Verio exceeded the "Terms of Use" since all search robots were forbidden from making requests on the site. The court concluded that Verio was therefore criminally liable under CFAA's section 1030(a). ${ }^{264}$

Establishing "Terms of Use" or "Terms of Access" is the most obvious way that a competitor may render a rival's access to its website "unauthorized." However, it is not the only way. In EF Cultural Travel BV v. Explorica, Inc. ${ }^{265}$ the court considered whether a confidentiality agreement could provide the same limitation on access. The data in this case were pricing, routing, and associated information ${ }^{266}$ about vacation packages offered by EF, a specialist in cultural and student tours. The information was publicly available on EF's website. Explorica, a competitor in the student cultural and language vacation market ${ }^{267}$ commissioned a programmer to write a routine program that scraped all of the information from EF's publicly accessible site. Explorica had knowledge of EF's fare structure since it had hired one of EF's ex-employees. It was therefore a simple task to write an automated query agent that, as with the agent in Register.com, Inc. v. Verio, Inc., sent a series of requests to EF's web server and collected the responses in a database maintained by Explorica. ${ }^{268}$ Armed with this data, Explorica could offer similar or identical tours to EF, and, with knowledge of EF's pricing structure, could systematically undercut EF. EF sought a preliminary injunction to stop Explorica's actions.

There was no question that Explorica had accessed anything other than information that was publicly available. The district court found that placing material on the Web did not affect the analysis of whether the access was unauthorized, concluding that EF's copyright notice "should have dispelled any notion a reasonable person may have had that the 'presumption of open access' applied to information on EF's Website."269 Since the information accessed by Explorica is almost certainly not copyright, ${ }^{270}$ and since website proprietors plaster copyright notices with unthinking abandon, it is hard to argue that the copyright notice alone was sufficient to make the access unauthorized, particularly because the copyright notice did not mention access. Perhaps as a result, the court of appeals

263. Id. at 251 .

264. Id. at 252-53.

265. 274 F.3d 577 (1st Cir. 2001).

266. Id. at 579 .

267. Id.

268. Id.

269. Id. at $\mathbf{5 8 0}$ (quoting the district court).

270. See Feist Publ'ns, Inc. v. Rural Tel. Serv. Co., 499 U.S. 340 (1991) (holding that the mere alphabetical arrangement of data in a telephone directory does not confer copyright, and that copyright in data compilations is "thin") 
did not rely on this as the touchstone of authorization or de-authorization. Instead, it looked to the unusual fact that EF's ex-employec, now a vice president of Explorica, had signed a confidentiality agreement when an employee of EF. This agreement included a clause to the effect that the employee would not disclose any confidential information to the outside world. ${ }^{271}$ As a result, the court concluded that Explorica's subsequent access was unauthorized, ${ }^{272}$ even though it is quite clear that the website information was in the public domain and was therefore, by definition, not confidential.

In both the spam and the website cases, the information deemed to have been unlawfully accessed was publicly accessible but subject to limitations on its use. Typically, these limitations were described in a "Terms of Use" document available somewhere on the website, ${ }^{273}$ or provided via a clickwrap agreement, ${ }^{274}$ though other bases of limitation were present in unusual circumstances. ${ }^{275}$ Whatever the basis for the limitations, courts have generally found unauthorized access for the purposes of the CFAA where the cyberspace owner simply objected to access. ${ }^{276}$

The CYBERSPACE AS PLACE metaphor explains why the results in these cases are anything but surprising, even if, as I will argue shortly, they have dire implications. ${ }^{277}$ Cyberspace is a place that conforms to our understanding of the physical world, with private spaces such as websites, email servers, and file servers, connected by the public thoroughfares of the network connections. Viewed through the filter of the CYBERSPACE AS PLACE metaphor, computer trespass does not just infringe on one's right to use the personal property of one's computer system. Instead, the action becomes a

271. EF Cultural Travel BV, 274 F.3d at 582 .

272. The court relied on the "insider" requirements of $\S 1030(\mathrm{e})(6)$, defining "'exeeed[ing] authorized access,' as accessing 'a computer with authorization and [using] such access to obtain or alter information in the computer that the accesser is not entitled so to obtain or alter," to conclude that the ex-employee "exceeded authorized access." $I d$. at 582.

273. See, e.g., Register.com, Inc. v. Verio, Inc., 126 F. Supp. 2d 238, 241 (S.D.N.Y. 2000).

274. "A clickwrap license presents the user with a message on his or her computer screen, requiring that the user manifest his or her assent to the terms ...." Specht v. Netscape Communications Corp., 150 F. Supp. 2d 585, 593 (S.D.N.Y. 2001).

275. See, e.g., EF Cultural Travel BV, 274 F.3d at 577 (finding a limitation in ex-employee's confidentiality agreement); Intel Corp. v. Hamidi, 114 Cal. Rptr. 2d 244 (2001) (finding a limitation stemming from a request not to send targeted emails to employees), reh'g granted, 43 P.3d 587 (2002).

276. See Register.com, Inc., 126 F. Supp. 2d at 251. But see In re Am. Online, lnc., 168 F. Supp. 2d 1359 (S.D. Fla. 2001) (refusing to expand the CFAA to encompass cases in which access was granted and scope of authorization was subsequently exceeded). As this Article went to press, the First Circuit published its opinion in EF Cultural Travel BV v. Zefer Corp., 2003 WL 174756 (Ist Cir. 2003). In dicta, the court attempted to settle the meaning of "exceeds authorized access" in 18 U.S.C. $\S 1030$ for the purposes of publicly accessible websites. It concluded that "an explicit statement on the website restricting access" is the basis for determining scope of access, unless the restriction "violates public policy." Id. at *3. Though there are numerous problems with this reasoning of the court, the decision does not affect the discussion here. The majority of "de-authorizing" statements will be found in website "Terms of Use," and the analysis presented here remains the same.

277. Infra Part IV. 
trespass against a form of quasi land that exists online. Trespasses to land have always been considered more serious than the equivalent actions against personal property. For example, an action lies for the most trivial trespass to land, whereas trespasses to chattels have always required serious damage. ${ }^{278}$

Anyone who enters my space without authorization is a trespasser. Private spaces may allow people entry under certain conditions, which may be posted on the door or otherwise communicated to them. ${ }^{279}$ This has its cyber equivalent: the "Terms of Use" of a website or the terms contained in the robot exclusion file are just like conditions of entry posted on a physical-world door ${ }^{280}$ Other mechanisms of removing access authorization would include direct email contact ${ }^{281}$ or requirements in confidentiality agreements as seen in EF Cultural Travel BV v. Explorica, Inc. ${ }^{282}$ As a result of the CYBERSPACE AS PLACE metaphor, anyone using my website appears to be "entering" my place and should be treated just like an invitee at common law. ${ }^{283}$ If invitees overstep the bounds of their invitation then they become trespassers subject to the full foree of the law. Courts have had few qualms about applying the metaphor to reach this conclusion.

Laws proscribing computer and network trespass are the obvious starting point for the examination of the legal application of the CYBERSPACE AS PLACE metaphor because they conceive of cyberspace as a place that can be entered ${ }^{284}$ But such examination is not limited to laws that were

278. See Restatement (SECOND) OF ToRTs $\$ 218$, cmt. e (1965). The Restatement provides: The interest of a possessor of a chattel in its inviolability, unlike the similar interest of a possessor of land, is not given legal protection by an action for nominal damages for harmless intcrmeddlings with the chattel. In order that an aetor who interferes with another's chattel may be liable, his conduct must affect some other and more important intercst of the possessor ... in the physical condition, quality, or value of the chattcl, or if the possessor is deprived of the usc of the chattel for a substantial time.

Id. Cyberspace cases on trespass to chattels have ignored this distinction and found trespass to private property even without significant evidence of damage. See infra Part 111.C.

279. See William L. Prosser et al., Cases and Materials on Torts 80 (8th ed. 1988).

280. See Robots Exclusion, at http://www.robotstxt.org/wc/exclusion.ht.nl (last visited Sept. 30, 2002).

281. See, e.g., Intel Corp. v. Hamidi, 114 Cal. Rptr. 2d 244, 251-52 (2001), reh'g granted, 43 P.3d 587 (2002).

282. 274 F.3d 577, 585 (1st Cir. 2001).

283. See Kermarec v. Compagnie Generalc Transatlantique, 358 U.S. 625 (1959) (outlining trcatment of invitees and eliminating distinction between invitee and licensee at common law).

284. There are many other criminal laws that rely on the CYBERSPACE AS PLACE metaphor. The Elcctronic Communications Privacy Act is the most prominent other example. Since it is closely associated with the application of Fourth Amendment jurisprudence to cyberspace, it is discussed infra Part 111.D. Laws proscribing the transportation of child pornography, 18 U.S.C.A. $\$ \S 2,2252(a)(1)-(2)$, have interpreted the Internet as providing the mechanism of transportation. See United States $v$, Mohrbacher, 182 F.3d 1041 (9th Cir. 1999) (holding those responsible for making child pornography available on a computer bullctin board or sending them to customers by email properly charged with and convieted of shipping or transporting sueh images). Laws against stalking may apply to online stalking, which might encompass following a victim into multiple chat rooms and abusing her. See 
expressly designed to address computer and Internet issues. For example, recently, the moribund tort of trespass to chattels was resurrected and applied wholesale to the Internet. This tort is very similar to the criminal computer trespass material covered here, and indeed courts have treated the two interchangeably.

\section{B. Resurrecting Trespass to Chattels}

If courts have been speedy in accepting the CYBERSPACE AS PLACE metaphor within the CFAA, then their reaction to it within tort law has been positively jaw dropping. Notwithstanding scholars' early suggestions of its inappropriateness, ${ }^{285}$ courts have rushed to resurrect the late, largely unlamented tort of trespass to chattels and apply it to the new cyberspace arena. The rise of this extraordinary-and extraordinarily damagingdevelopment can, I think, be explained by the CYBERSPACE AS PLACE metaphor.

Perhaps the leading case in this area is $e B a y, I n c . v$. Bidder's Edge, Inc. ${ }^{286}$ eBay, the major Web-based auction site, created a huge following for its online auctions. It was, and remains, the major player in online auetions. ${ }^{287}$ Bidder's Edge ran the website, "AuctionWatch.com," which aggregated auetion details of many online auction sites, including eBay's. ${ }^{288}$ An AuetionWatch.com user could see on a single screen all of the auction sites offering a particular type of product, rather than having to search many different auction sites separately. In order to provide this service, Bidder's Edge sent out automated software query agents ("robots" or "bots"), to inquire (or "crawl") on auction sites. ${ }^{289}$ Similar to the situation in Register.com, Inc. v. Verio, Inc., these queries were standard requests that individually were indistinguishable from a human making the same request. ${ }^{290}$ The information from eBay's site was reported back to Bidder's Edge and collected in its database. ${ }^{291}$

Marczeski v. Law, 122 F. Supp. 2d 315 (D. Conn. 2000) (accepting the idea that antistalking law might apply online but concluding that the claim was subsumed under an asserted harassment claim).

285. See Chris Reed, Controlling World Wide Web Links: Property Rights, Access Rights and Unfair Competition, 6 Ind. J. Global Legal Stud. 167 (1998). But see Dan L. Burk, The Trouble with Trespass, 4 J. Small \& EMErging Bus. L. 27 (2002) (arguing against the tort and suggesting nuisance as, arguably, a more appropriate tort); 1 . Trotter Hardy, The Ancient Doctrine of Trespass to Web Sites, 1996 J. ONLINE L. art. 7 (Oct. 1996), at http://www.wm.edu/law/publications/jol/95_96/ hardy.html (arguing that trcspass might be applied to unwanted website usage).

286. 100 F. Supp. 2d 1058 (N.D. Cal. 2000). Though this case brought the "chattel trespass" approach to common attention, prior chattel trespass cases exist. See Burk, supra note 285, at 28-33 (discussing cases leading to $e$ Bay.).

287. eBay, Inc., 100 F. Supp. $2 \mathrm{~d}$ at 1060.

288. Id. at 1061-62.

289. Id. at 1061 .

290. See supra note 258 and associated text. The only difference is in the number of requests made in a given time-frame: being automated, the bot can make significantly more requests per second.

291. eBay, Inc., 100 F. Supp. 2d at 1061-62. 
eBay was unhappy about these automated enquiries, allegedly because the requests from the bots placed a heavy load on its servers. ${ }^{292}$ It therefore sought to enjoin Bidder's Edge from using its bots to send requests to the eBay site. eBay argued that the trespass to chattels tort should be revived and applied to this new scenario, and the court concurred. ${ }^{293}$

eBay's most striking claim involved an analogy between the physical world and the virtual one: "eBay's allegations of harm are based, in part, on the argument that [Bidder's Edge]'s activities should be thought of as equivalent to sending in an army of 100,000 robots a day to check the prices in a competitor's store." 294 This analogy relies directly on the CYBERSPACE AS PLACE metaphor: the idea that physical world robots can be mapped onto virtual software "bots" involves an acceptance that the virtual world is a space that can be roamed like the physieal one. The court, however, did not accept eBay's argument-but not because it rejected the CYBERSPACE AS PLACE metaphor. In fact, the court enthusiastically accepted the metaphor but found the resulting harm de minimis:

This analogy, while graphic, appears inappropriate. Although an admittedly formalistic distinction, unauthorized robot intruders into a "brick and mortar" store would be committing a trespass to real property.... [F]or the analogy to be accurate, the robots would have to make up less than two out of every one-hundred customers in the store, the robots would not interfere with the customers' shopping experience, nor would thc robots even be seen by the customers. Under such circumstances, there is a legitimate claim that the robots would not pose any threat of irreparable harm. ${ }^{295}$

The CYBERSPACE AS PLACE metaphor was operating here, even though the court did not ultimately accept eBay's argument. ${ }^{296}$ The court did not reject the extraordinary idea that Bidder's Edge's bots had invaded eBay's virtual space; it allowed this on its face, but concluded that there was insufficient damage to grant the injunction. The court did, however, grant a preliminary injunction on another of eBay's claims. ${ }^{297}$ The basis of the court's decision was that Bidder's Edge was engaged in a trespass to chattels, ${ }^{298}$ a tort similar to the more familiar tort of conversion, but involving a lesser degree of annexation of the personal property. ${ }^{299}$ The court outlined the

292. Id. at 1063-65. Presumably the action also had something to do with the fact that a commercial competitor with a better, albeit derivative, service was gaining market share at eBay's expense.

293. Id. at 1064-69.

294. Id. at 1065 .

295. Id. at 1065-66 (footnote omitted).

296. Id.

297. Id. at 1066-70.

298. Id. at 1069.

299. See Thifty-Tel, Inc. v. Bezcnek, 54 Cal. Rptr. 2d 468, 473-74 (1996) (redefining trespass to chattels and applying it to the new telecommunications regime). 
necessary elements that a plaintiff must establish for a chattel trespass claim in relation to computer systems: "(1) defendant intentionally and without authorization interfered with plaintiff's possessory interest in the computer system; and (2) defendant's unauthorized use proximately resulted in damage to plaintiff." 300

Prior to $e B a y$, there were a number of lesser-known cases on cyberspace chattel trespass, where the issue was whether sending unsolicited bulk email via a free email system involved a chattel trespass to the provider of the system. ${ }^{301}$ Courts in these cases readily adopted this theory of liability, no doubt because it amounted to one of the few ways to fight the scourge of spam in the absence of legislative assistance. While we might have hoped it would be limited to these egregious situations, courts after $e B a y$ have enthusiastically embraced the expansion of the tort and have applied it whole-heartedly to situations well beyond the narrow confines of spam. In both the EF Cultural Travel $B V v$. Explorica, Inc. and Register.com, Inc. v. Verio, Inc. decisions, trespass to chattels was adopted by the courts in addition to the criminal computer trespass provisions discussed above. ${ }^{302}$ Most recently, in Intel $v$. Hamidi, the California courts extended the principle to prohibit the regular sending of emails to employees of a corporation that had previously requested that the email not be sent. ${ }^{303}$ Ken Hamidi, a disgruntled ex-employee of Intel Corporation, sent a few emails to many Intel employees, complaining of various injustices. ${ }^{304}$ The court focused on the large number of employees to whom Hamidi sent his messages, rather than the character or number of unique emails, and applied the approach of the earlier trespass to chattels cases to this new scenario to enjoin Hamidi from sending future emails to Intel employees. ${ }^{305}$ Although some courts have declined to apply this tort to specific situations - typically where the use of the computer system was de minimis ${ }^{306}$ the evolution of the trespass to chattels action, from spam, through

300. eBay, Inc., 100 F. Supp. 2d at 1069-70.

301. See Am. Online, Inc. v. GreatDeals.net, 49 F. Supp. 2d 851 (E.D. Va. 1999) (finding spammers liable for trespass to chattels); Am. Online, lnc. v. LCGM, Inc., 46 F. Supp. 2d 444 (E.D. Va. 1998); Am. Online, Inc. v. IMS, 24 F. Supp. 2d 548 (E.D. Va. 1998) (same); CompuServe lnc. v. Cyber Promotions, Ine., 962 F. Supp. 1015, 1021 (S.D. Ohio 1997) (same). See generally Steven E. Bennett, Canning Spam: Compuserve, Inc. v. Cyber Promotions, Inc., 32 U. Rich. L. Rev. 545 (1998); Burk, supra note 285.

302. EF CuItural Travel BV v. Explorica, Inc., 274 F.3d 577, 585 (1st Cir. 200 I); Registcr.com, Inc. v. Verio, Inc., I26 F. Supp. 2d 238, 249-50 (S.D.N.Y. 2000).

303. Intel Corp. v. Hamidi, I I4 Cal. Rptr. 2d 244, 250 (2001), reh'g granted, 43 P.3d 587 (2002).

304. Id. at 246-47.

305. Id. at 251-52.

306. See Oyster Software, Inc. v. Forms Processing, Inc., 2001 U.S. Dist. LEXIS 22520 (N.D. Cal. Dec. 6, 2001) (finding that there was no showing that the use complained of interfered to any extent with the regular business of the plaintiff); Ticketmaster Corp. v. Tickets.com, Inc., 2000 WL 1887522 , at *4 (same), aff'd, 248 F.3d 1173 (9th Cir. 2001). 
websites, and culminating in regular email, demonstrates the importance of the CYBERSPACE AS PLACE metaphor.

There are three pieces of evidence that the metaphor is operating in this new field of cyberspace tort. First, there is the nature of the chattel that is allegedly trespassed upon. Recall that it is the plaintiff's personal property that is supposed to be the subject of the tort. Initially, in $e$ Bay the court did focus on the personal property of the computer or the "computer system." ${ }^{307}$ However, later in the decision, the court's analysis expanded to suggest that the chattel included the plaintiff's bandwidth and server capacity. ${ }^{308}$ It is revealing that this line of cases struggles to define the chattel at issue. At times the courts suggest that the chattel is simply the computer, but more often it is a nonspccific combination of computer, bandwidth, ${ }^{309}$ capacity, ${ }^{310}$ processing power, ${ }^{311}$ or network. ${ }^{312}$ With the exception of the computer itself, none of these "chattels" are actually chattels at all. There is no private property in bandwidth or processing power or network.

It seems here that courts are trying to reconcile the CYBERSPACE AS PLACE metaphor with the personal property basis of the chattel trespass theory. At times the personal property feature emerges, as when the focus is placed upon the computer itself. ${ }^{313}$ Other times, the notion of the computer as an aspect of place emerges, as when the focus is placed on spatial characteristics such as the plaintiff's bandwidth, capacity, processing, or network characteristics.

There is a second piece of evidence supporting the argument that the CYBERSPACE AS PLACE metaphor is used in trespass to chattels. Contrary to

307. eBay, Inc. v. Bidder's Edge, Inc., 100 F. Supp. 2d 1058, 1070 (N.D. Cal. 2000) (finding that the defendant "interfercd with plaintiff's possessory interest in the computer system").

308. Id. at 1071. Initially the court was careful to indicate that the subject of trespass was the computer system, which was affcctcd by Bidder's Edge's use of the bandwidth and capacity. Id. (focusing on the "diminished ... quality or value of eBay's computer systems"). Later the bandwidth and capacity becamc the chattels in question:

It is undisputed that eBay's server and its capacity are personal property, and that BE's searehes use a portion of this property. Even if, as BE argues, its searches use only a small amount of eBay's computcr system capacity, BE has nonetheless deprived eBay of the ability Id. to use that portion of its personal property for its own purposes.

309. See id.

310. See id.

311. See CompuServe, Inc. v. Cyber Promotions, Inc., 962 F. Supp. 1015, 1022 (S.D. Ohio 1997).

312. See Am. Online, Inc. v. IMS, 24 F. Supp. 2d 548, 550 (E.D. Va. 1998); Am. Online, lnc. v. LCGM, Inc., 46 F. Supp. 2d 444, 452 (E.D. Va. 1998).

313. See Ticketmaster Corp. v. Tickets.com, lnc., 2000 WL 1887522, at *4, aff'd, 248 F.3d 1173 (9th Cir. 2001). The district court explains:

The computer is a piece of tangible personal property. It is operated by mysterious electronic impulses which did not exist when the law of trespass to chattels was devcloped, but the principles should not bc too different. If the electronic impulscs can do damage to the computer or to its function in a comparable way to taking a hammer to a piecc of machinery, then it is no stretch to reeognize that damage as trespass to chattels and provide a legal remedy for it. 
the typical application of torts to personal property, ${ }^{314}$ courts in the cyberspace arena have largely ignored the damage requirement of the tort. When commentators first treated the trespass to chattels action as applicable to the cyberspace arena, they agreed that a plaintiff would have difficulty in establishing the necessary damage to the chattel in question, suggesting that such an action would fail in a cyberspace case. ${ }^{315}$ Of course, the opposite is true. In most cases, the courts have ignored the damage requirement or been extremely flexible in determining what damage is sufficient. ${ }^{316}$ The conclusion therefore seems to be that the tort is much more like trespass to real property, since real property trespasses have always been considered more serious and actionable without proof of damage. ${ }^{317}$ As Dan Burk has concluded, by ignoring the harm requirement, the courts that developed trespass to chattels in the arena "esscntially reversed several hundred years of legal evolution, collapsing the separate doctrines of trespass to land and trespass to chattels back into their singlc common law progenitor: the action for trespass." 318 Because the CYBERSPACE AS PLACE metaphor made personal property seem more like real property, the two different causes of action have become conflated.

The final piece of evidence that the CYBERSPACE AS PLACE metaphor rules in this old-made-new tort is the language that the courts use. This language unconsciously reveals the courts' characterization of the action. This is, of course, exactly what the Lakoffian metaphor theory teaches us, $^{319}$ and the examples in this area are particularly striking. Courts applying the trespass to chattels theory often forget that they are supposed to be talking about personal property, and describe the defendant's actions as though they were trespassing on a place. For example, in Intel v. Hamidi, when the court dismissed the defendant's First Amendment claim it noted that the ACLU's amicus brief "cites cases which confer First Amendment protection in private tort actions, but they differ from the present case in

314. See Prosser, supra note 279, at 80 (requiring damage for trespass to chattels)

315. See Susan M. Ballantine, Computer Network Trespasses: Solving New Problems with Old Solutions, 57 WASH. \& LEE L. REv. 209, 248-49 (2000) (observing that "failure to allege or to support a showing of actual harm should have precluded lntel from prevailing on a trespass to chattels theory" but arguing that trespass to land should be applied here); Burk, supra note 285, at 39 ("[T] he elements of common law trespass to chattels fit poorly in the context of cyberspaee, and so the courts have been able to apply this claim to the problem of spam only by virtue of creative tailoring ....").

316. See, e.g., Intel Corp. v. Hamidi, 114 Cal. Rptr. 2d 244, 250 (2001) (noting and dismissing the Electronic Frontier Foundation's slippery slope argument against the court's application of liability in nonspam contexts: "if such loss of productivity is the applicable standard [of harm], then every personal email that an employee reads at work could constitute a trespass.'"), reh'g granted, 43 P.3d 587 (2002). See generally Burk, supra note 285, at 33-38 (demonstrating that courts have ignored damage requirements in trespass to chattels, thereby making it functionally identical to trespass to land).

317. See supra note 278 and accompanying text.

318. Burk, supra note 285 , at 33.

319. Supra Part 11.B-C. 
that Hamidi was enjoined from trespassing onto Intel's private property. ${ }^{, 320}$ One can only trespass on land or a cyberspace equivalent. The court should have said that Hamidi trespassed against Intel's personal property, or some other language that indicated that the chattel was misappropriated or abused. Instead, the court clearly had the real-property action in mind when it dismissed the First Amendment claim. Indeed, this view is bolstered by looking at the cases it cited in support of its conclusion, most of which involved the posting of material in real-property locations such as shopping centers and hardware stores. ${ }^{321}$ Earlier it had characterized Hamidi's actions as "invading [Intel's] internal, proprietary email system," 322 and characterized Hamidi's use of the system as "entry" into their system. ${ }^{323}$ All of these examples show how the court was conceiving the chattels-based tort in real-property terms. The CYBERSPACE AS PLACE metaphor explains why the courts think this way within the tort arena.

\section{The Cyberspace Constitution}

There is, by now, a vast literature on the application of constitutional law to cyberspace. Within this literature, two significant threads examine the protections granted by, respectively, the First and the Fourth Amendments. In both of these areas the CYBERSPACE AS PLACE metaphor has had important effects.

\section{Public Parks in Cyberspace}

Minds are not changed in streets and parks as they once were. To an increasing degree, the more significant interchanges of ideas and shaping of public consciousness occur in mass and electronic media. ${ }^{324}$

The ideal of the public forum suggests a place where citizens can congregate, air their grievances, debate public policy, and be confronted with new thoughts and arguments. Archetypal public forums include the Athenian Senate and Hyde Park's Speaker's Corner, and the myth of their influence and importance is hard to dispel. ${ }^{325}$ Mythical or otherwise, the

320. 114 Cal. Rptr. 2d at 254.

321. The cases cited were NAACP v. Claiborne Hardware Co., 458 U.S. 886 (1982) (enjoining the defendants from picketing or patrolling the premises of hardware store); Org. for a Better Austin $v$. Keefe, 402 U.S. 415 (1971) (deciding a case regarding leaflets distributcd in a shopping center and posted on neighbors' doors); Blatty v. N.Y. Times Co., 728 P.2d 1177 (Cal. 1986) (deciding a case regarding omission of plaintiff's book from the newspaper's Bestseller List); and Paradise Hills Assocs. v. Procel, I Cal. Rptr. 2d 514 (Cal. Ct. App. 1991) (addressing signs posted on defendant's house and on other neighbors' houses).

322. Hamidi, 114 Cal. Rptr. 2d at 250.

323. Id.

324. Denver Area Educ. Telecomm. Consortium, Inc. v. Fed. Communications Comm'n, 518 U.S. 727, 802-03 (1996) (Kennedy, J., concurring in part and dissenting in part).

325. See Dan Hunter, Philippic.com, 90 Calif. L. Rev. 611 (2002). 
concept of the public forum holds a central place in the deliberative democracy ideal that is dominant in modern democracy theory. ${ }^{326}$ In addition, it plays a fundamental role in First Amendment jurisprudence, and has done so since Justice Roberts's dictum in Hague v. Committee for Industrial Organization. ${ }^{327}$

Because the Internet is also a setting where people present and debate arguments, numerous articles have proselytized for the application of the public forum doctrine to cyberspace. ${ }^{328}$ Initially, these articles voiced concern that courts might be unwilling to extend the public forum doctrine to the virtual forum of the Internet. ${ }^{329}$ However, courts had revcaled their willingness to protect "metaphysical" spaces as strongly as physical ones. ${ }^{330}$

326. See, e.g., Bruce A. Ackerman, Social Justice in the Liberal State (1980); Joseph M. Bessette, The Mild Voice of Reason: Deliberative Democracy and american National. Government (1994); John S. Dryzek, Discursive Democracy: Politics, Policy, and Political SCience (1990); John H. Ely, Democracy and Distrust: A Theory of Judicial Review (1980); James S. Fishrin, Democracy and Deliberation: New Directions for Democratic Reform (1991); James S. Fishrin, The Voice of the People: Public Opinion and Democracy (1995); amy Gutmann \& Dennis Thompson, Democracy and Disagreement (1996); Jürgen Habermas, Between Facts and Norms: Contributions to a Discourse of law and Democracy (William Rehg trans., 1996); John Rawls, Political Liberalism (1993); Joshua Cohen, Deliberation and Democratic Legitimacy, in Deliberative Democracy 67 (James Bohman \& William Rehg eds., 1997). For a discussion of how this notion can be translated into cyberspace, see CaSS R. SUNSTEIN, Republic.com (2001) and Cass R. Sunstein, The First Amendment in Cyberspace, 104 Yale L.J. 1757, 1786 (1995).

327. 307 U.S. 496 at 515 (1939). The Court held:

Wherever the title of streets and parks may rest, they have immemorially been held in trust for the use of the public and, time out of mind, have been used for purposes of assembly, communicating thoughts between citizens, and discussing public questions. Such use of the streets and public places has, from ancient times, been a part of the privileges, immunities, rights, and liberties of citizens.

Id.

328. See, e.g., David J. Goldstone, A Funny Thing Happened on the Way to the Cyber Forum: Public vs. Private in Cyberspace Speech, 69 U. Colo. L. Rev. 1, 6 (1998) (advocating nuanced consideration of how public forum doctrine might apply to different modes of cyberspace communication) [hereinafter Goldstone, Funny Thing]; David J. Goldstone, The Public Forum Doctrine in the Age of the Information Superhighway (Where Are the Public Forums on the Information Superhighway?), 46 HaSTINGS L.J. 335 (1995) (suggesting an analytical framework for identifying publie forums on the Internet) [hereinafter Goldstone, Where]; Timothy Wu, ApplicationCentered Internet Analysis, 85 VA. L. Rev. 1163,1170 n. 13 (1999) (noting that the Supreme Court's treatment of First Amendment issues in cyberspace bears substantial similarities to public forum doctrine).

329. See Edward V. DiLello, Functional Equivalency and Its Application to Freedom of Speech on Computer Bulletin Boards, 26 Colum. J.L. \& Soc. Probs. 199 (1993) (examining how online and offline communications may be equivalent); Allen S. Hammond, IV, Private Networks, Public Speech: Constitutional Speech Dimensions of Access to Private Networks, 55 U. PIrT. L. Rev. 1085 (1994) (discussing conditions where private networks have public characteristics); Allen S. Hammond, IV, Regulating Broadband Communication Networks, 9 YALE J. ON Reg. 181 (1992) (same); Edward J. Naughton, Is Cyberspace a Public Forum? Computer Bulletin Boards, Free Speech, and State Action, 81 GEo. L.J. 409, 428-41 (1992) (examining conditions under which the public forum doctrine could apply to public message areas of early bulletin board systems).

330. See Rosenberger v. Rector \& Visitors of the Univ. of Va., 515 U.S. 819, 830 (1995) (extending the public forum doctrine to the "metaphysical"); see also Ark. Educ. Television Comm'n v. 
The question then became the appropriate characterization of the public forum within cyberspace. Rather than treat all of cyberspace as one undifferentiated space, some scholars suggested instead that there are multiple forums in cyberspace. ${ }^{331}$ As we become more familiar with cyberspace, we have come to consider some of these forums as clearly having public character, ${ }^{332}$ while others are of a limited public nature, and some are clearly nonpublic spaces. ${ }^{333}$ So, for example, David Goldstone suggested that chatrooms, news groups, and certain types of email discussion lists should be considered public forums, ${ }^{334}$ based upon a set of criteria mapped from the physical space. ${ }^{335}$ Antithetically, Timothy $\mathrm{Wu}$ argued that email does not have a public character; ${ }^{336}$ therefore, applying the public forum doctrine to one's private email account would correctly permit unsolicited bulk email and other evils. Other commentators analyzed the application of the public forum doctrine to othcr cyberspace features such as links on statesponsored websites. ${ }^{337}$

The approach courts have taken when applying the public forum doctrine, or other First Amendment principles, supports the suggestion that cyberspace in fact contains multiple forums. ${ }^{338}$ In Reno v. $A C L U,{ }^{339}$ the

Forbes, 523 U.S. 666, 676 (1998) (applying public forum analysis to broadcast of election debate by state-owned public television broadcaster); Cornelius v. NAACP Legal Def. \& Edue. Fund, 473 U.S. 788 (1985) (applying public forum analysis to solicitation of donations for nonprofit charities by a federal organization); Perry Educ. Ass'n v. Perry Local Educators' Ass'n, 460 U.S. 37, 46-54 (1983) (applying public forum analysis to public school mail facilities).

331. E.g., Goldstone, Funny Thing, supra note 328, at 10 (arguing that cyberspace should be treated for public forum purposes not as a single forum, but as a city with many forums within it, some of which should be treated as public forums and others of which should not).

332. Id. at 8 ("Some, although by no means all, of these forums can be characterized as public forums. As more Americans become inereasingly comfortable with cyberspace, the claim that certain portions of the Internet deserve or require 'public forum' status will become compelling.").

333. Id.; Eugene Volokh, Freedom of Speech in Cyberspace from the Listener's Perspective: Private Speech Restrictions, Libel, State Action, Harassment, and Sex, 1996 U. CHI. LEGAL F. 377, 407-10 (1996).

334. See Goldstone, Funny Thing, supra note 328, at 10, 18-19.

335. The criteria are that "(1) [the cyber forum] is owned or controlled by the government; (2) it is not operated at a profit; (3) it has unrestricted aecess for recipients of forum messages; and (4) [the forum] affords viewpoint-neutral access to a reasonably large number of senders." Goldstone, Where, supra note 328 , at 383.

336. Wu, Internet Analysis, supra note 328, at 1167-69.

337. R. Johan Conrod, Linking Public Websites to the Public Forum, 87 VA. L. REv. 1007 (2001) (arguing that the speech present in web links is a revolutionary form of speech that renders inapplicable almost all of the traditional justifications for speech regulation, even those justifications approved in the public forum context).

338. Contrast this with the analysis made with respect to cable and public access television. See Ark. Educ. Television Comm'n v. Forbes, 523 U.S. 666 (1998) (holding against the applieation of publie forum doctrine to cable television, but carving out exeeption for political debate); Denver Area Educ. Telecomms. Consortium v. Fed. Communieations Comm'n, 518 U.S. 727 (1996) (holding against the application of public forum doctrine to cable tclevision); $\mathrm{c} f$. Turner Broad. Sys. v. Fed. Communications Comm'n, 512 U.S. 622, 636 (1994) (concluding that the First Amendment applied to cable television). See generally Conrod, supra note 337, at 1015-20; Robert Kline, Freedom of Speech 
Supreme Court struck down provisions of the Communications Decency $\mathrm{Act}^{340}$ on First Amendment grounds. Although the Court did not invoke the public forum doctrine explicitly, it was clearly influenced by it. As Steven Gey has noted, ${ }^{341}$ the Court's very language assumed that the Internet has extremely strong public forum characteristics. For example, the Court observed that the Internet includes "vast democratic forums"342 with content "as diverse as human thought." ${ }^{343}$ The court not only invoked the public forum trope of the pamphleteer handing out leaflets on a street corner, ${ }^{344}$ but also relied on a seminal public forum case. ${ }^{345}$ While the facts of the case were such that the Court was not required specifically to apply or endorse the public forum doctrine, members of the Court appeared to assume that cyberspace has public forum characteristics. As a result, after Reno some have argued that applying the public forum doctrine is the best way to resolve First Amendment concerns online. ${ }^{346}$

Part of the reason the Court did not adopt the public forum doctrine in Reno can be explained by the distributed nature of the content under consideration. The pornography that the Communications Decency Act sought to regulate, and which was the subject of Reno, can be found in disparate corners of the Internet, from websites to news groups to private emails. As a result, the concerns expressed above about applying the public forum doctrine to cyberspace as a whole, rather than to individual forums within cyberspace, militated against the use of the doctrine. The Reno Court did not seek to apply the public forum doctrine to all Internet places, since to do so would lead to overbroad protection for some types of content. It is

on the Electronic Village Green: Applying the First Amendment Lessons of Cable Television to the Internet, 6 CORNELL J.L. \& PUB. POL'y 23 (1996).

339. Reno v. ACLU, 521 U.S. 844, 849 (1997) (striking down two provisions of the Communications Decency Act as abridging the freedom of speech protected by the First Amendment). See also Cyberspaee Communications, lnc. v. Engler, 55 F. Supp. 2d 737 (E.D. Mich. 1999) (holding that a Michigan statute adding criminal prohibitions against using eomputers or the Internet to disseminate sexually explicit materials to minors violated the First Amendment).

340. 47 U.S.C. $\S \S 223(a)(1)(B)(i i), 223(d)$ (1996).

341. See Steven G. Gey, Reopening the Public Forum-From Sidewalks to Cyberspace, 58 Оноо ST. L.J. 1535, 1610-18 (1998) [hereinafter Gey, Sidewalks].

342. Reno, 521 U.S. at 868.

343. Id. at 852 (quoting Reno v. ACLU, 929 F. Supp. 824, 842 (E.D. Pa. 1996)).

344. Id. at 870 ("Through the use of Web pages, mail exploders, and newsgroups, the same individual can become a pamphleteer.").

345. Id. at 880. The Court reasons:

The Government's position is equivalent to arguing that a statute could ban leaflets on certain subjects as long as individuals are free to publish books. In invalidating a number of laws that banned leafletting on the streets regardless of their content, we explained that "one is not to have the exercise of his liberty of expression in appropriate places abridged on the plea that it may be exercised in some other place."

Id. (quoting Schneider v. State of N.J. (Town of Irvington), 308 U.S. 147, 163 (1939)).

346. See Gey, Sidewalks, supra note 341, at 1610-18 (arguing for application of public forum analysis in multiple online contexts). But see Wu, Internet Analysis, supra note 328, at 1167-69 (noting the unintended dangers of applying public forum analysis to the online world). 
therefore an exceedingly good thing that the Court did not apply the public forum doctrine here.

This difficulty has not occurred with other types of Internet content, notably unsolicited bulk email. In some early spamming cases, ${ }^{347}$ courts considered whether email constituted a public forum. The cases revolved around the activities of a professional spammer, Cyber Promotions, which made its livelihood from sending vast numbers of emails daily. ${ }^{348}$ As in the other spam cases discussed previously, ${ }^{349}$ large ISPs sought to stop the spammer from abusing the email facilities that they provided for their subscribers by suing the spammer for "trespass to chattels" 350 or by returning the emails in a form likely to crash the spammer's server. ${ }^{351}$ In response, the spammer argued that the email systems werc public forums, and the ISP's actions violated its First Amendment rights. ${ }^{352}$ The courts dismissed these arguments. Public forum doctrine did not apply to these sorts of cases since (I) the forum to which the speech right was asserted was privately created; and (2) the entity that asserted the right was motivated by purely private purposes and was attempting to engage in "commercial speech" related to those purposes. ${ }^{353}$ The ISPs were not state actors, nor did their private conduct have the character of state action. ${ }^{354}$

Interestingly, the courts did not refuse to apply the public forum doctrine to this type of Internet resource. Instead, they applied the usual scope limitations of the public forum doctrine, and concluded that private places in cyberspace, as in the physical world, ${ }^{355}$ are not public forums. Courts have been willing to consider applying public forum doctrine to email systems in theory, although they have been loath to find the necessary

347. Cyber Promotions, Inc. v. America Online, Inc., 948 F. Supp. 436 (E.D. Pa. 1996); CompuServe, Inc. v. Cyber Promotions, Inc., 962 F. Supp. 1015 (S.D. Ohio 1997). A third case involving the same plaintiff and defendant at around the same time dealt with an antitrust claim against the ISP. See Cyber Promotions, Inc., 948 F. Supp. at 459.

348. Cyber Promotions, Inc., 948 F. Supp. at 438 (explaining how Cybcr Promotion's activities burdened email servers by sending millions of messages cach day).

349. Supra Part IIl.B-C. See, e.g., notc 301.

350. See CompuServe, Inc., 962 F. Supp. 1015; see also supra Part Ill.B-C (discussing trespass to chattels).

351. Cyber Promotions, Inc., 948 F. Supp. at 436.

352. Id. at 436-37; CompuServe, Inc., 962 F. Supp. at 1015-17.

353. See Cyber Promotions, Inc., 948 F. Supp. at 446; CompuServe, Inc., 962 F. Supp. at 1025-26.

354. See Cyber Promotions, Inc., 948 F. Supp. at 441-45; CompuServe, Inc., 962 F. Supp. at 102527; see also Grecn v. America Online, 2003 WL 135811 (3rd Cir. 2003) (finding equivalent New Jersey constitutional principles inapplicablc to an ISP).

355. See Pruneyard Shopping Ctr. v. Robins, 447 U.S. 74, 88 (1980) (holding that a state is free to determine whether a private mall accessible to community is a public forum); Hudgens v. NLRB, 424 U.S. 507, 518-21 (1976) (finding that a privatc mall accessible to community was not a public forum). See generally Harvey Rishikof \& Alexander Wohl, Private Communities or Public Governments: "The State Will Make the Call," 30 VAL. U. L. Rev. 509, 537-38 (1996) (discussing privatc cntities as public forums). 
characteristics of the public space present. ${ }^{356}$ Commentators have suggested a number of situations where a public forum might yet be found: for example, a private email system used for voting, ${ }^{357}$ or a situation where more extensive state law protections apply. ${ }^{358}$ It seems that email might sometimes be properly deemed a public forum in the future, but it has been limited by the situations presented to date..$^{359}$

Courts have applied public forum analysis to other types of cyberspace content-most notably government-sponsored websites. In Putnam Pit $v$. City of Cookeville, ${ }^{360}$ the analysis revolved around a city-owned website for the City of Cookeville, Tennessee, that regularly provided links to other sites of interest. The proprietor of a tabloid newspaper and website, The Putnam Pit, had investigated an unsolved murder that occurred in Cookeville. He asked the city to provide a link from its site to The Putnam Pit. The city refused, and the proprietor of The Putnam Pit sued, alleging, among other things, that his First Amendment rights had been infringed since the city's website was a public forum. ${ }^{361}$ The district court held that the website at issue was a nonpublic forum. ${ }^{362}$ The Sixth Circuit agreed, ${ }^{363}$ focusing initially on the requirement laid down in Hague v. Committee for Industrial Organization 364 that the public forum be "devoted to assembly and debate." 365 Though the initial formulation of the public forum doctrine required that the forum have been used since "time out of mind," 366 the Sixth Circuit did not reject the idea that forums might exist in more modern environments. ${ }^{367}$ However, the website at issue, which contained tax and tourist information, job listings, and city news, ${ }^{368}$ did not provide any place for assembly and debate. ${ }^{369}$ Since there was no "free exchange of ideas between members of the public," there was no public forum. ${ }^{370}$

Considering whether there was a possible designated or limited public forum, the court asked whether the city had made the website available to

356. See, e.g., Intel Corp. v. Hamidi, I14 Cal. Rptr. 2d 244 (200I), reh'g granted, 43 P.3d 587

(2002).

357. Goldstone, Funny Thing, supra note 328, at 20-22.

358. Id. at 23-27.

359. But see $\mathrm{Wu}$, supra note 328 , at 1167 (noting that the Supreme Court's treatment of First Amendment issues in eyberspace bears substantial similarities to public forum doctrine).

360. 221 F.3d 834 (6th Cir. 2000).

361. Id. at 839-41.

362. Putnam Pit v. City of Cookeville, 23 F. Supp. 2d 822, 831 (M.D. Tenn. 1998).

363. Putnam Pit, 221 F.3d at 834, 844.

364. 307 U.S. 496, 515 (1939).

365. Id. at 842 (quoting Perry Educ. Ass'n v. Perry Local Educators' Ass'n, 460 U.S. 37, 45 (1983)).

366. Hague, 307 U.S. 496 at 515.

367. Putnam Pit, 221 F.3d at 843 (quoting Int'l Soc'y for Krishna Consciousness v. Lee, 505 U.S. 672, 697-98 (I992) (Kennedy, J, concurring)).

368. Id. at 841 .

369. Id.

370. Id. at 843 . 
an entire class of speakers. ${ }^{371}$ The court concluded that it had not: "Cookeville had not provided open access to links to the city's site, whereby anyone could set up their own link from the city's site to an outside Website without going through the city on a one-by-one basis." 372 The court then examined whether "the exclusion of certain expressive conduct is properly designed to limit the speech activity occurring in the forum to that which is compatible with the forum's purpose." ${ }^{373}$ Again, the court rejected the plaintiff's claims. The website was similar to a bulletin board, and was intended to provide information to the community. The site did not allow free expression, and was hence not a public forum. ${ }^{374}$ The point here, of course, is not what the court eventually concluded, but rather that it accepted that notion that a website is a place that might have public forum characteristics.

When applying First Amendment jurisprudence and specifically the public forum doctrine to cyberspace, I suggest that courts and commentators have adopted the CYBERSPACE AS PLACE metaphor. ${ }^{375}$ Though courts may eventually reject the doctrine's application to various online spaces, this is no different from rejecting it in the physical world. Even where courts conclude that a website or email system is private, they nevertheless analyze these Internet systems as if they were physical spaces. And where, as in Putnam Pit, courts conclude that website links are not public forums, the CYBERSPACE AS PLACE metaphor has led judges to conclude that the Internet can be analyzed in the same way that we analyze physical forums.

\section{Searching Cyberspace}

The opening clause of the Fourth Amendment guarantees " $[t]$ he right of the people to be secure in their persons, houses, papers, and effects, against unreasonable searches and seizures." ${ }^{376}$ The Framers' well-known motivation underlying this clause was to remove forever the threat of "writs of assistance," the hated British warrants that allowed

371. Id. at 843-44.

372. Id. at 844 .

373. Id. at $843-44$.

374. Id. at 844 .

375. Other aspects of cyberspace have received sustained First Amendment analysis, although not in a way that relies on the CYBERSPACE AS PLACE metaphor. Most notable here are cases on domain names and the First Amendment. See, e.g., Name.Space, Ine. v. Network Solutions, Ine., 202 F.3d 573 (2d Cir. 2000) (finding that the existing Internet generic Top Level Domains (gTLDs) are not protected speech because the domain name system limits them to three-letter extensions lacking in expressive content); Nat'l A-1 Adver., Inc. v. Network Solutions, Inc., 121 F. Supp. 2d 156 (D.N.H. 2000) (holding that the portion of an Internet address containing second-level domain name was not a discrete forum for speeeh, precluding a claim that the entity responsible for registering proposed domain names violated applicant's First Amendment rights by denying registration on grounds that proposed names wcre vulgar); PGMedia, Inc. v. Network Solutions, Inc., 51 F. Supp. 2d 389 (S.D.N.Y. 1999) (holding that domain names did not constitute "speech" for First Amendment purposes).

376. U.S. ConsT. amend. IV. 
pre-Revolutionary officers of the Crown discretion "to search suspected places for smuggled goods." 377 Suspicionless searches used as a form of oppression were "perhaps the most prominent event[s] which inaugurated the resistance of the colonies ....."378

Since it was intended to protect against property-based warrants, early Fourth Amendment jurisprudence focused on requirements of space and place. The Amendment protects people generally from searches and seizures. Specifically, the three basic spaces of protection are the citizens' physical selves ("persons"), their real property ("houses"), and their personal property ("papers, and effects"). ${ }^{379}$ Early judicial interpretations enshrined this spatial assumption. Justice Bradley's majority opinion in the Supreme Court's first significant, ${ }^{380}$ and most venerated, ${ }^{381}$ examination of the Fourth Amendment, Boyd v. United States, ${ }^{382}$ focused on governmental incursions on private property. The government sought to subpoena defendant Boyd's papers in an action against a firm that was accused of improperly claiming customs exemptions for plate glass. ${ }^{383}$ The Court rejected the government's request, reasoning that individuals had a property interest in their home that restricted "all invasions on the part of the government and its employees of the sanctity of a man's home and the privacies of life." 384 Boyd's papers were Boyd's property; the private property interest outweighed the government's interest in policing customs violations. ${ }^{385}$

For many years, Fourth Amendment cases followed this spatially oriented reasoning. Government searches were limited where they entered "constitutionally protected areas." 386 In a line of cases starting with Hester v. United States ${ }^{387}$ and ending with Mapp v. Ohio, ${ }^{388}$ the Supreme Court

377. Boyd v. United States, 116 U.S. 616, 625 (1886).

378. Id.

379. See Orin Kerr, The Problem of Perspective in Internet Law, 91 Geo. L.J. (forthcoming Feb. 2003) (arguing that both internal and external perspeetives ean be used in analyzing lnternet laws, and applying this prineiple in seareh and seizure cases); Erik G. Luna, Sovereignty and Suspicion, 48 DuKE L.J. 787, 838 (1999) (discussing spatial assumptions of Fourth Amendment).

380. There were two Fourth Amendment opinions prior to Boyd. See Ex Parte Jaekson, 96 U.S. 727, 733 (1877); Livingston v. Moore, 32 U.S. 469, 482 (1883). Both summarily concluded, without signifieant analysis, that the Amendment was violated.

381. According to Justice Brandeis, Boyd "will be remembered as long as civil liberty lives in the United States." Olmstead v. United States, 277 U.S. 438, 474 (1928). Justice Frankfurter called it "the guide to the interpretation of the Fourth Amendment to whieh the Court has most frequently reeurred." Harris v. United States, 331 U.S. 145, 160 (1947) (Frankfurter, J., dissenting). Alexander Bickel called the decision "a shining and enduring demonstration" of the proper role of history in constitutional interpretation. Alexander M. Bickel, The Original Understanding and the Segregation Decision, 69 HaRv. L. Rev. 1, 5 n. 14 (1955).

382. 116 U.S. $616(1886)$.

383. Id. at 618 .

384. Id. at 630 .

385. Id. at 631-32

386. Berger v. New York, 388 U.S. 41, 59 (1967).

387. 265 U.S. 57 (1924) (holding that "open fields" were not eonstitutionally proteeted areas). 
outlined a series of protected and unprotected places. ${ }^{389}$ However, by the late 1960 s this bright-line test came to be seen as too limited, too inflexible, and intellectually suspect. A new test emerged that removed space and property as the touchstones of regulation and instead assessed whether the searched party had a "reasonable expectation of privacy" upon which the government search improperly intruded. ${ }^{390}$

The new test maintained constitutional protections while removing the somewhat inflexible and increasingly unpalatable limiting effect of the narrower property requirement. ${ }^{391}$ For example, under the old test, wiretapping a defendant's home telephone had not been considered an unconstitutional search, since the wiretapping occurred on public phone lines and not in defendant's house ${ }^{392}$ Under the new test, wiretapping a public phone booth was held to be a Fourth Amendment violation because the defendant had a reasonable expectation of privacy while talking on the phone: "What a person knowingly exposes to the public, even in his own home or office, is not a subject of Fourth Amendment protection. But what he seeks to preserve as private, even in an area accessible to the public, may be eonstitutionally protected." ${ }^{.393}$

The CYBERSPACE AS PLACE metaphor affects courts' application of these principles in two basic ways. First, the "reasonable expectation of privacy" standard has been used to frame a significant portion of the ongoing online privacy debate, at least as it concerns the role of government actors and law enforcement in monitoring online communications and transactions. Various courts and commentators have examined the privacy expectations inherent in sending email or storing material on a private computer or network disk. This analysis tends to focus on the user's expectations as a reflection of whether society considers the space searched public or private. Private spaces simply are more likely to confer an expectation of privacy. In some cases, such as those involving a publicly accessible chat room, ${ }^{394}$ the online environment has characteristics of a

388. 367 U.S. 643 (1961) (relying on "protected areas" doctrine, which was replaced after this case with the "reasonable expectations of privacy" principle).

389. See, e.g., Lanza v. New York, 370 U.S. 139, 143 (1962) (finding that protected areas include house, office, store, hotel room, automobile, and taxicab, but not the visitors' room of a jail).

390. Terry v. Ohio, 392 U.S. 1, 9 (1968); Katz v. United States, 389 U.S. 347, 351 (1967).

391. See Michael Adler, Note, Cyberspace, General Searches, and Digital Contraband: The Fourth Amendment and the Net-Wide Search, 105 YALE L.J. 1093, 1100-01 (1996).

392. Olmstead v. United States, 277 U.S. 438, 471 (1928).

393. Katz, 389 U.S. at 351-52 (citations omitted). Other examples of the spatial emphasis of Fourth Amendment jurisprudence include the scope limitations on search warrants, see Walter $v$. United States, 477 U.S. 649, 657 (1980) (holding that the Fourth Amendment "requires that the scope of every authorized search be particularly described"), and the special rules for particular places, see Ronald J. Allen \& Ross M. Rosenberg, The Fourth Amendment and the Limits of Theory: Local Versus General Theoretical Knowledge, 72 ST. JoHN's L. Rev. 1149 (1998).

394. United States v. Charbonneau, 979 F. Supp. 2d 1177, 1184-85 (S.D. Ohio 1997) (finding that the defendant had no reasonable expectation of privacy in mcssage sent to a chat room). See also 
public space: anyone who happens to be in the chat room at the time can read posted messages. Here the user has no reasonable expectation of privacy. Other communications clearly are intended for only a few people, such as the content of email, if not the message header information of that email. ${ }^{395}$ Communications in other spaces may fall somewhere between these two extremes: instant messages to a small buddy list might be public or private depending on who can read the messages. When it comes to translating the Fourth Amendment directly into the online world, the CYBERSPACE AS PLACE metaphor still structures our understanding.

The second major way the CYBERSPACE AS PLACE metaphor has significantly influenced the application of Fourth Amendment analysis to the Internet is through the Electronic Communications Privacy Act. ${ }^{396}$ This Act was intended to extend Fourth Amendment protections to the online world, and it reflects similar CYBERSPACE AS PLACE conceptions. The phrasing of the Act's fundamental protection against retrieval of "stored communications" 397 implies that the user has placed these communications in a private "space." Where Fourth Amendment principles are translated into the online environment, either by courts or legislative pronouncements, the CYBERSPACE AS PLACE metaphor has exerted a significant hold over our understanding of the best way to guarantee our civil rights.

\section{Zoning, Jurisdiction, and Names}

[T] he Roman pantheon gave a proud place to Terminus, god of boundaries. Today, the maps negotiated by politicians and drafted by urban planners are patchworks of ownership boundaries, zoning boundaries, and jurisdictional boundaries. Within jurisdictional borders, local laws and customs apply, local power is exerted by some over others .... But bits answer to terminals, not Terminus; these lines on the ground mean little in cyberspace. ${ }^{398}$

"Zoning" is the physical-space mechanism by which local municipalities restrict land use to fulfill societal objectives such as physically separating children from adult entertainment establishments. ${ }^{399}$ The rationale behind this spatial mechanism has been extremely influential in the scholarly and judicial conception of cyberspace. Notable here is Lawrence

\footnotetext{
United States v. Hambrick, 55 F. Supp. 2d 504, 508-09 (W.D. Va. 1999) (denying Fourth Amendment protection for user's subscriber information obtained from an ISP), aff'd, 225 F.3d 656 (4th Cir. 2000) (unpublished opinion); United States v. Kennedy, 81 F. Supp. 2d 1103, 1110 (D. Kan. 2000) (reaching a similar result).

395. See 18 U.S.C. $\S 3127(4)$ (1995) (permitting law enforcement to extract packet header information and addressing information from Internet communications in the same way as addressing information for traditional phone calls, which carry expectations of privacy).

396. Pub. L. No. 99-508, 100 Stat. 1848 (codified at 18 U.S.C. $\$ \S 2510-2522,2701-2711$ (1994)).

397. 18 U.S.C. $\$ 2710(2000)$.

398. MitCHELL, supra note 1, at 147.

399. See City of Renton v. Playtime Theatres, 475 U.S. 41 (1986).
} 
Lessig's work, which formulated a conception of "cyber-zoning" in which parts of the Web are made off-limits to children and other vulnerable groups. ${ }^{400}$ The concept of "cyber-zoning," so obviously dependent on the CYBERSPACE AS PLACE metaphor, pervades the discourse of legislative and judicial institutions. For example, Justice O'Connor in Reno v. ACLU described the Communications Decency Act as "little more than an attempt by Congress to create 'adult zones' on the Internet." ${ }^{\text {"401 }}$ She concluded that government regulations limiting or denying access to sexually explicit speech found on the Internet were akin to impermissible "zoning laws."

There is a flipside to the idea of online zoning. In some cases, websites have escaped liability precisely because they are not subject to physical world zoning laws. In Voyeur Dorm, L.C. v. City of Tampa, Fla., an adult website called voyeurdorm.eom was webcasting pornographic material from a house in a residential zone in Tampa, Florida. ${ }^{403}$ The city brought an action claiming that the site's operators were violating the city's zoning ordinances, and the district court agreed. ${ }^{404}$ However, the court of appeals reversed, concluding that the adult content was not viewable from the street, and that, within the physical world, for all intents and purposes the house was only put to residential use. Because the adult content was available only online, no physical world zoning laws were breached. ${ }^{405}$

Discussions of online jurisdiction also have strong spatial overtones. The most obvious example of this is in the seminal article by David Johnson and David Post, Law and Borders. ${ }^{406}$ Johnson and Post articulated a theory of Internet governance that presumed both that existing geographical divisions are incapable of regulating the Internet and that members of Internet communities can regulate themselves. ${ }^{407}$ Implicit in this theory is the idea that cyberspace is a separate, identifiable place that can be regulated as a space unto itself.

400. See LEssiG, supra note 24; Lawrence Lessig, What Things Regulate Speech: CDA 2.0 vs. Filtering, 38 JURIMETRICS J. 629 (1998) (applying zoning to speech generally); Lawrence Lessig \& Paul Resnick, Zoning Speech on the Internet, 98 Mich. L. REv. 395 (1999) (examining the concept of zoning certain aspccts of cyberspace, notably pornographic content).

401. 521 U.S. 844, 886 (1997) (O'Connor, J., concurring in part and dissenting in part).

402. Id.

403. 265 F.3d 1232, 1233 (1 l th Cir. 2001),

404. Voyeur Dorm, L.C. v. City of Tampa, FL, 121 F, Supp. 2d 1373, 1378 (M.D. Fla. 2000).

405. Voyeur Dorm, 265 F.3d at 1236. The court explains:

The City Code eannot be applied to a location that does not, itself, offer adult entertainment to the public. As a practical matter, zoning restrictions are indelibly anehored in particular geographic locations. ... It does not follow, then, that a zoning ordinance designed to restriet facilities that offer adult entertainment can be applied to a particular location that does not, at that location, offer adult entertainment.

ld.

406. See Johnson \& Post, supra note 6.

407. Id. 
As discussed previously, the Johnson-Post theory has met resistance. ${ }^{408}$ National legal systems have not abdicated their claims to authority over the new "place" of cyberspace, but rather have sought to apply the traditional jurisdictional approaches to this new environment. ${ }^{409}$ This, however, does not lcssen the force of the CYBERSPACE AS PLACE metaphor. Physical spaces may trump virtual spaces in the jurisdiction stakes, but this does not change our deeply held conception of cyberspace as a place.

Finally, we see evidence that domain names have property-like characteristics under some circumstances. A number of cases have examined whether interests in domain names involve contract or property intcrests. Though the preferred thinking seems to be that any remedies for domain namc problems involvc purely contractual questions, ${ }^{410}$ in some respects domain names seem like real property. For example, the Anticybersquatting Consumer Protection Act, which prohibits abusive domain name registration, has a provision that grants in rem jurisdiction to a court based on the locale of registration of the domain name. ${ }^{411}$ In rem jurisdiction, of course, assumes some property, even though in this case the domain name registration is nothing more than an entry in the registrar's database. The appropriateness of the in rem provisions is the subject of some debate. ${ }^{412}$ However, it is unquestioned that it seems perfectly natural for Congress and courts to treat domain names as though they are property. Indeed, one commentator argues that domain names bear almost all of the economic and philosophical characteristics of real property, and so should be protected as such. ${ }^{413}$

The above examples demonstrate the hitherto unrecognized importance and the pervasive character of the CYBERSPACE AS PLACE metaphor within cyberspace law and regulation. The examples have provided only a description of the regulatory environment and demonstrated the evidence of the metaphor's pervasiveness. I have not considered whether the metaphor is a good or bad thing, or whether the effects of the metaphor are desirable or not. However, the next Part considers the normative implications of the metaphor. I argue that it is leading us inexorably towards an undesirable policy outcome: the staking out of private claims in cyberspace and concomitant reductions in the public "ownership" of the spaee. I explain

408. See supra Part I.A.

409. See id; ;ee also Goldsmith, Against Cyberanarchy, supra note 38, at 1239-4I.

4I0. See Zurakov v. Register.com, Inc., No. C600703/01 (N.Y. Sup. Ct. July 27, 200I), available at http://decisions.courts.state.ny.us/nyscomdiv/AUG01/600703-01-002.PDF.

411. I5 U.S.C.A. § 1125 (d) (2002).

412. Catherine T. Struve \& R. Polk Wagner, Realspace Sovereigns in Cyberspace: Problems with the Anticybersquatting Consumer Protection Act, 17 Berkeley TeCH. L.J. 989 (2002).

413. Kenton K. Yee, Location, Location, Location: Internet Addresses as Evolving Property, $6 \mathrm{~S}$. CAL. INTERDISC. L.J. 20I (1997). 
this effect and suggest why and how we might resist the impact of the metaphor.

\section{IV \\ The Digital Anticommons}

Cyberspace is opening up, and the rush to claim and settle is on..$^{414}$

In the fifteenth century, landholding in England began to change profoundly. In various ways, the gentry appropriated for private ownership land that had been held in common by many people. ${ }^{415}$ This was called the "enclosure movement" after the fencing and enclosing of the commons by these new private landholders. ${ }^{416}$ That most fundamental of property rights, the right to exclude, ${ }^{417}$ was used to alter the default mode of land tenure from commons property to private property. This default mode remains to this day, ${ }^{418}$ although there are some notable exceptions. ${ }^{419}$

Recently, a similar process has been occurring within intellectual property. Commentators have begun to note the increasing private control of what previously had been intellectual commons property. James Boyle has called this the "second enclosure movement." ${ }^{40}$ He and other scholars have detailed the movement toward private control within intellectual property $^{421}$ and the concomitant erosion of the public domain. ${ }^{422}$ The

414. Mitchell, supra note 1 , at 167.

415. See generally J.A. Yelling, Common Field and Enclosure in England 1450-1850, 7-95 (1977).

416. See id. at 5-6 (discussing the creation of physical boundaries with such things as ditches and hedges to sct off private space).

417. See Kaiser Aetna v. United States, 444 U.S. 164, 176 (1979) (characterizing "the right to cxclude others" as "one of the most essential sticks in the bundle of rights that are commonly characterized as property").

418. For an account of the rise of the enclosure movement, see Daniel R. Coquillette, Mosses from an Old Manse: Another Look at Some Historic Property Cases About the Environment, 64 CORNELL L. Rev. 761, 807-09 (1979).

419. Reeently, significant analysis has focused on limited-commons property regimes, in contrast to previous discussions that emphasized a division between completcly private and completely public systems. See Perspectives on Property Law xii (Robert C. Ellickson et al. eds., 2d ed. 1995) (citing a shared dormitory room as common property); Robert C. Ellickson, Property in Land, 102 YALE L.J. $1315,1394-95$ (1993) (noting that the majority of Americans live in limited-commons property environments within multiperson households).

420. BoYle, supra note 2; see also Jamcs Boyle, Cruel, Mean, or Lavish? Economic Analysis, Price Discrimination and Digital Intellectual Property, 53 VAND. L. REv. 2007, 2010 (2000) ("Over the last twenty years, there has been an enormous cxtension of intellectual property; a far-ranging enclosure movement over the public domain, paralleling the eighteenth century's enclosure of common lands.").

421. See Benjamin Kaplan, An Unhurried View of Copyright (1967) (noting the historical trend to increased intellectual property rights); Yochai Benkler, Free as the Air to Common Use: First Amendment Constraints an Enclosure of the Public Domain, 74 N.Y.U. L. REv. 354, 354-55 (1999) ("We are in the midst of an enclosure movement in our information environment. In other words, our society is making a series of decisions that will subject more of the ways in which cach of us uses information to somcone else's exclusive control."); Yochai Benkler, Siren Songs and Amish 
enclosure of the intellectual commons takes many forms: ongoing term extensions for copyright ${ }^{423}$ (such that few works have moved from copyright into the public domain for decades); ${ }^{424}$ scope extensions for patents to include business methods, ${ }^{425}$ lifeforms, ${ }^{426}$ and genome sequences; ${ }^{427}$ new intellectual property rights for hitherto unprotected collections of facts; ${ }^{428}$ the erosion of fair use in areas such as parodies ${ }^{429}$ and decompilation of computer programs,${ }^{430}$ and the rise of digital rights management systems. ${ }^{431}$

Children: Autonomy, Information, and Law, 76 N.Y.U. L. REv. 23, 112 (2001) (arguing that the information enclosure movement "is a serious cause for concern in terms of autonomy, for it increasingly subjects the cultural commons from which we draw to form our understandings of the world to the control of a small number of professional commercial producers"); Yochai Benkler, $A n$ Unhurried View of Private Ordering in Information Transactions, 53 VAND. L. Rev. 2063, 2063 (2000) (explaining "why economic justifications interposed in favor of this aspect of the enclosure movement are, by their own terms, undetermined"). See also Elizabeth L. Eisenstein, The Printing ReVolution in EarLy Modern Europe 83-84 (1983) (describing the enclosure of the literary "commons" following the emergence of printing privileges for publishers, booksellers, and stationers).

422. For a variety of perspectives on the inroads made by privatization into public domains in intellectual property, see Dan L. Burk, Muddy Rules for Cyberspace, 21 CARDozo L. Rev. 121 (1999) (identifying public domain shrinkage in digital media); Julie E. Cohen, Copyright and the Jurisprudence of Self-Help, 13 BERKELEY TECH L.J. 1089 (1998) (noting the importance of contract to attempts to reduce public domain); Paul A. David, A Tragedy of the Public Knowledge "Commons"? Global Science, Intellectual Property and the Digital Technology Boomerang (Stanford lnstitute for Economic Policy Research, SIEPR Policy Paper No. 00-02, 2000) (explaining how the rise in sui generis database protection reduces scientific public domain); Mark A. Lemley, Beyond Preemption: The Law and Policy of Intellectual Property Licensing, 87 CALIF. L. Rev. 111 (1999) (identifying the Uniform Computer Information Transaction Act and contract law as reducing the commons in copyright); Jessica Litman, The Public Domain, 39 EmoRY L.J. 965 (1990) (explaining the importance of public domain to creativity and innovation).

423. Copyright Term Extension Act ("CTEA"), Pub. L. No. 105-298, 112 Stat. 2827 (1998).

424. See Hearing on S. 483, The Copyright Term Extension Act of 1995, Before the Senate Comm. on the Judiciary, 104th Cong. (Sept. 20, 1995) (Statement of Peter Jaszi, Professor, Washington College of Law, American University) (characterizing the CTEA as a "perpetual copyright on the installment plan"); see also Lawrence Lessig, The Future of Ideas: The Fate of the Commons IN A CONNECTED WORLD (2001) (analyzing the eonstitutional deficiencies of the CTEA).

425. State Street Bank \& Trust Co. v. Signature Fin. Servs., 149 F.3d 1368 (Fed. Cir. 1999); see also LESSIG, supra note 424; BoYLE, supra note 2, at 5.

426. See BoYLE, supra note 2, at 4.

427. See id. at 6; see also Arti Rai, Regulating Scientific Research: Intellectual Property Rights and the Norms of Science, 94 Nw. U. L. Rev. 77 (1999) (noting concerns with propertization of human genome data).

428. See Directive 96/9/EC of the European Parliament and of the Council of 11 March 1996 on the Legal Protection of Databases, 1996 O.J. (L77) 20 (creating sui generis scheme for protection of noncopyright database); Collections of Information Anti-Piracy Act, H.R. 354, 106th Cong. (1999) (attempting the same within the United States); see also BoyLE, supra note 2, at 5-6 (detailing dangers in expanding private ownership of data).

429. See BoYLE, supra note 2, at 6 .

430. Id.

431. The two most notable examples are the Secure Digital Music Initiative ("SDMl") and the DVD Copy Control Association ("DVD-CCA"). See Secure Digital Music Initiative, at http://www.sdmi.org (last visited Jan. 29, 2003) (describing SDMI); DVD Copy Control Ass'n, lnc. v. McLaughlin, 2000 WL 48512 (Cal. Super. Ct. Jan. 21, 2000) (describing DVD-CCA). See generally BoYLE, supra note 2, at 6 . 
The trend toward increased private control is so obvious that it is no longer confined to earnest scholarly musings; courts are now being asked to consider the problem. Recently, the Supreme Court decided Eldred $v$. Ashcroft,${ }^{432}$ putting down a challenge to congressional extensions of copyright terms, and concluding that this practice does not offend the constitutional mandate that copyright may be granted only for a limited period. ${ }^{433}$

If intellectual property is the subject of the second enclosure movement, then the Internet is the subject of a related trend, one we can term the "cyberspace enclosure movement." This movement began when online actors, who had cheerfully reaped the benefits of the online commons, decided to stake out their own little claims in cyberspace. They then began to use the law to fence off their cyberholdings, keep out intruders, and "privatize" the abstract space that once had all the characteristics of a commons.

The previous Parts of this Article have detailed the ways we think of cyberspace as a place. In law, places are real estate and tend to become private property; and so the next section describes the property-based analysis to which courts have turned in regulating cyberspace. Specifically, Part IV.A shows how concepts from real property have led to the cyberspace enclosure movement and the resulting treatment of cyberspace places as private landholdings. From this, we see a splintering of the Internet commons into virtual private holdings.

"So what?" we might conclude. Private ownership of resources is not problematic in itself; indeed, private ownership is generally considered the most efficient form of allocating property resources, and the economic history of the last five hundred years has been characterized by the movement from the public to the private. The quintessential example of the benefits of private ownership is, of course, Garrett Hardin's tragedy of the commons: public resources are overused and destroyed where there is no private property interest in limiting their use. ${ }^{434}$ However, as Michael Heller has recently demonstrated, private ownership can lead to the opposite phenomenon: the tragedy of the anticommons. ${ }^{435}$ The anticommons effect occurs when multiple parties can prevent others from using a given resource so that no one has an effective right of use. Thus, multiple rights of exclusion lead to inefficient underuse of the resource. Part IV.B argues that this is precisely where the CYBERSPACE AS PLACE metaphor leads. The rise of the cyberspace enclosure movement is creating a digital anticommons, in which no one will be allowed to access competitors' cyberspace "assets"

432. Eldred v. Reno, 239 F.3d 372 (D.C. Cir. 2001), aff'd sub nom., Eldred v. Ashcroft, 123 S. Ct. 769 (2003).

433. U.S. Const., art. 1, § 8, cl. 8; see also LESSIG, supra note 424.

434. Garrett Hardin, The Tragedy of the Commons, 162 Scl. 1243, 1244-45 (1968); see also infra Part I1.B.

435. See Heller, supra note 15; see also infra Part IV.B. 
without either licensing access or agreeing to some other transactionally expensive permission mechanism. Opposing this trend, Part IV.C suggests that we must restore the digital commons. We need to recognize that commons property in cyberspace is desirable, and is not subject to the usual tragedies of the commons.

\section{A. The Cyberspace Enclosure Movement}

If we think of cyberspace as a place, then the legal response would be to impose a real-property-based regulatory structurc on the place. Moreover, because our physical world property system is based on private land tenure, the legal reaction is to use real-property mechanisms to delineate and fence off these new property entitlements in cyberspace.

However, the Internet initially assumed a number of commons-like features. Indeed, without these commons characteristics, the Internet would not be what it is today. The most fundamental Internet process-ofinformation transfer is a good example. No centralized server arranges transfer of packets in the system; the transfer of data from one computer to another is entirely dependent on many computcrs voluntarily transferring packets to the next machine in the path, ${ }^{436}$ a process called "pcering." Until recently peering was performed largely for free, as a matter of network etiquette and out of recognition that the common benefit of the network depended on this process. ${ }^{437} \mathrm{~A}$ similar process initially characterized email transport. Until the advent of spam, many email servers maintained an "open relay" for email. ${ }^{438}$ These relays permitted transfer of email messages from systems that did not have the resources to provide email to their users or were unable to accommodate the Internet's email protocol. ${ }^{439}$ In essence, email relay servers donated their processor and bandwidth to systems less fortunate than themselves. ${ }^{440}$ Resource donation also occurred elsewhere in cyberspace. As Lawrence Lessig notes, the University of Chicago has allowed anyone to connect to its network and use the

\footnotetext{
436. "Peering" involves the following process:
}

Larger ISPs with their own backbone networks agree to allow traffic from other large ISPs in exchange for traffic on their backbones. They also exchange traffic with smaller ISPs so that thcy can rcach regional end points. Esscntially, this is how a number of individual network owners put the Internet together.

See "pcering," TechTarget Network Whatis definition, at http:/scarchnetworking.techtarget.com/ sDefinition/0,,sid7_gci212768,00.html (last visited Apr. 3, 2002).

437. See id.

438. Open Relay Database, Why Do Open Relays Represent a Problem, at http:/www.ordb.org/ faq/\#why-a-problem (last visited Nov. 12, 2002).

439. See "Open Relay," TechTarget Network Whatis Definition, at http://searchnetworking. techtarget.com/sDefinition/0,,sid27_gci782509,00.html (last visited Apr. 3, 2002) ("An open relay (sometimes called an insecure relay or a third-party relay) is an SMTP email server that allows thirdparty relay of email messages .... In effect, the owner of the scrver ... donates nctwork and computer resources to the sender's purpose.").

440. Id. 
Internet. ${ }^{441} \mathrm{~A}$ more recent example is the proliferation of wireless Internet access points, many of which provide their access for free. ${ }^{442}$ Free access, free relay, and free peering-for the common benefit of all. Commons property defined the early architecture of the Internet. ${ }^{443}$

Consider, too, the various services and protocols that function above the fundamental architecture, starting with the masterstroke that defines the Web: the ability to link to every other website. The links are a free and creative endeavor of themselves, and have generated tremendous network externalities. ${ }^{444}$ More than this, many individual websites adopt the commons mentality. Project Gutenberg scans and places public domain texts on the Web for all to use. ${ }^{445}$ Project Perseus translates Ancient Greek and Latin texts into English and posts them. ${ }^{446}$ Napster, Gnutella, Morpheus, and Kazaa encourage the wholesale sharing of files, ${ }^{447}$ much to the anger of the music industry and others. ${ }^{448}$

Many examples exist. ${ }^{449}$ Free and shared resources, created for the betterment of all, are the online norm, not the exception-so much so that online content companies bemoan the "gift economy" of the Internet and the difficulty of getting anyone to pay for the digital content they want to sell. ${ }^{450}$ Nevertheless, the digital commons is under attack. The cyberspace enclosure movement threatens to privatize much of the nctwork's commons.

\section{Property and Invitees}

Let's say that I am a consumer retailer, or a parking garage operator, or an accountant. I own, or via lease have a right of exclusive possession

441. Lessig, supra note 24 , at 26-27.

442. See Cauldron of Innovation, Bus. WK., Apr. 1, 2002, available at http://www.businessweek.com/technology/content/apr2002/tc2002041_3117.htm (last visited Apr. 1, 2002). An example of these free wireless networks can be found at NoCatNet, at http://www.nocat.net (last visited Apr. 2, 2002).

443. On the nature of the commons, see Elinor Ostrom, Governing the Commons (1990); Carol Rose, The Comedy of the Commons: Custom, Commerce, and Inherently Public Property, $53 \mathrm{U}$. Chi. L. Rev. 711 (1986).

444. Externalities that are coming under pressure directly by linking policies. Infra note 447 and associated text.

445. See Project Gutenberg, at http://promo.net/pg/ (last visited Apr. 3, 2002).

446. See Project Perseus, at http://www.perseus.tufts.edu/Perseuslnfo.html (last visited Apr. 3, 2002).

447. See Kelly Truelove \& Andrew Chasin, Morpheus out of the Underworld, O'Reilly P2P (July 2, 2001), at http://www.openp2p.com/pub/a/p2p/2001/07/02/morpheus.html (last visited Apr. 3, 2002).

448. See Richard Menta, RIAA and MPAA Sue Morpheus, Grokster, and KaZaa, MP3 newswire.net (Oct. 3, 2001), at http://www.mp3newswire.net/stories/2001/sue_morpheus.html (last visited Apr. 3, 2002).

449. For a comprehensive list of commons-like features of the Internet and related telecommunications infrastructure, see LEsSIG, supra note 424, at 17-100.

450. See, e.g., PBS, WGBH, \& Frontline, Interview with Stewart Brand (Founder of the WELL) (June 15, 1995), at http:/www.pbs.org/wgbh/pages/frontline/cyberspace/brand.html (last visited Apr. $3,2002)$. 
over, the premises where I do business. Of course I want you to come into my premises in order to shop, or park your car, or engage me to shred documents. However, I do not want you to have complete freedom of access to the premises, so I designate you an invitee or licensee, entitled to enter the premises under certain conditions. These conditions might include terms that you not steal the stock in the shop, or that you not sue me for scratching your car, or that you not stage a sit-in in my office. I post these conditions on the front door of the premises so that you can see them and be advised of the conditions of your invitation into the premises. ${ }^{451}$ The basic framework is this: property law guarantees your exclusion from my place, and contract law governs the terms of your entry into my place.

As detailed above, ${ }^{452}$ this is exactly what we see in cyberspace. The trespass to chattels and computer trespass actions, applied to cyberspace, operate using precisely this framework. You are forbidden from entering a cyberspace place except upon conditions set by the space's proprietor. Sometimes the space involved is a website, ${ }^{453}$ sometimes it is an email system. ${ }^{454}$ Sometimes the conditions are set by the "Terms of Use" of the site, ${ }^{455}$ while other times they are set by robot exclusion headers, ${ }^{456}$ confidentiality agreements, ${ }^{457}$ or a letter from a lawyer. ${ }^{458}$ However, the approach is the same. You are forbidden from entering my cyberplace unless you agree to my terms. If you access my place in defiance of my terms, then you lose your invitee status and become a trespasser, subject to both civil $^{459}$ and criminal action. ${ }^{460}$

Unlike the terms of entry in physical establishments, cyberspace "Terms of Use" are often extraordinarily broad, and grant extraordinary rights to the proprietor. The owners of the filesharing system Kazaa, Sharman Systems, outraged many users who discovered that by downloading Kazaa's peer-to-peer file-sharing software they had given unwitting permission to Kazaa to install additional software that allowed users' computers to be used for distributed computing tasks and other functions of

451. See Kermarec v. Compagnie Generale Transatlantique, 358 U.S. 625 (1959) (establishing the validity of terms provided to invitee and limiting liability for injuries sustained on premises).

452. Supra Part III.

453. See, e.g., EF Cultural Travel BV v. Explorica, 1nc., 274 F.3d 577 (1st Cir. 2001).

454. See, e.g., Intel Corp. v. Hamidi, I14 Cal. Rptr. 2d 244 (2001), reh'g granted, 43 P.3d 587 (2002).

455. See, e.g., Register.com, Inc. v. Verio, Inc., 126 F. Supp. 2 d 238 (S.D.N.Y. 2000). But see Specht v. Netscape Communications Corp., 150 F. Supp. 2d 585, $591-96$ (S.D.N.Y. 2001) (holding that "Terms of Use" by themselves could not bind person downloading software, where opportunity to present terms was otherwise available).

456. See, e.g., Register.com, Inc., I26 F. Supp. $2 \mathrm{~d} 238$.

457. See, e.g., EF Cultural Travel BV, 274 F.3d 577.

458. See, e.g., Hamidi, 114 Cal. Rptr. 2d 244.

459. See supra Part Ill.C.

460. Supra Part 111.B. 
which they were not fully aware. ${ }^{461}$ By using Microsoft products and websites nearly everyone has, at one time or another, (1) agreed to allow Microsoft to scan the contents of his or her PC and download whatever software it deems necessary, ${ }^{462}$ (2) agreed not to abuse anyone, ${ }^{463}$ (3) given Microsoft a license to use his or her email in any way it sees fit, ${ }^{464}$ and (4) agreed not to use Microsoft products to create any "objectionable" material, including material that disparages Microsoft. ${ }^{465}$

Other terms are impossible to understand, or purport to bind the user on an ongoing basis, no matter what changes to the terms the proprietors might make. For example:

You agree to the terms of this Agreement by using our Site. If you do not agree to these terms, you may not use this Site. We may modify this Agreement at any time with or without notice, by posting it on our Site and successive modification will become effective immediately. You agree to review this Agreement from time to time. ${ }^{466}$

And since every site has unique terms, users cannot "enter" sites with a reasonable understanding of what to expect based on experience. The legal expectation is that every user will read every "Terms of Use," no matter how complex or hard to find. And users must do this every time they go to an online place.

Some commercial operators of websites go so far as to post "Terms of Use" that forbid the quintessential Web mechanism of establishing a hypertext link to their site, except for certain narrow purposes. For cxample, the accounting firm KPMG claimed that only those who had negotiated a Web-linking agreement with them could include a link to their site. ${ }^{467}$ KPMG's lawyers threatened legal action against a commentary site that had been critical of KPMG if it did not remove the link to kpmg.com. ${ }^{468}$ Pitney Bowes, a stationery supplier, places a series of conditions upon anyone who would seek to link to their site: users must not imply

461. John Borland, Kazaa Exec Defends Sleeper Software, CNET NEws.COM (Apr. 3, 2002), at http://news.com.com/2 100-1023-875016.html (last visited Apr. 3, 2002).

462. Ed Foster, Check the Fine Print, INFOWORLD at http://www.infoworld.com/ articles/op/xml/02/02/11/02021 lopfoster.xml (last visited Apr. 3, 2002).

463. Microsoft .NET, Microsoft .NET Passport Terms of Use and Notices, at http://www.passport.com/Consumer/TermsOfUse.asp (last visited Apr. 3, 2002).

464. Microsoft .NET Passport, Microsoft Passport Web Site Terms of Use and Notices, at http://www.stanford.edu/class/ee380/Abstracts/TermsOfUse.010404.html (last visited Apr. 3, 2002).

465. Ed Foster, Disclosing Terms, 1NFoWorLD (Apr. 26, 2002), available at http://www.infoworld.com/article/02/04/26/020429opgripe_1.html (last visited Feb. 8, 2003).

466. ubhonline, Web Site Use Agreement, at http://www.ubhonline.eom $/ \mathrm{html} /$ UseAgreement.html (last visited Apr. 1, 2002).

467. Farhad Manjoo, Big Stink over a Simple Link, WiRED (Dec. 6, 2001), at http://www.wired.com/news/business/0,1367,48874,00.html (last visited Apr. 1, 2002).

468. Id. 
endorsement by Pitney Bowes and may not use its logo without permission. ${ }^{469}$

Countless other variants exist, their numbers limited only by the creativity of the lawyers who draft them: all links are forbidden except text links to the main domain name; ${ }^{470}$ only links from noncontroversial sites are permitted; ${ }^{471}$ or only links that do not adversely affect the linked-to site are allowed, ${ }^{472}$ however such harm might be construed. Other "Terms of Use" forbid the process of framing content in another page, in order to stop content aggregators from using their pages. ${ }^{473}$

Various cases have considered terms forbidding "deep linking" and "framing." " Courts have generally upheld these "Terms of Use" by using the computer criminal trespass and the trespass to chattels actions. ${ }^{475}$ And as with the original enclosure movements, law has bent to the interests of the private enclosers of the commons.

\section{The Consequences}

The enclosure of cyberspace represents a fundamental change in the way the Internet operates. Hitherto, cyberspace flourished because the default rule was to allow common access and use of resources. We now see

469. Pitney-Bowes, Linking Policy, at http://www.pb.com/cgi-bin/pb.dll/cditorials/pb_company editorial.jsp?contentKey=ed_8510\&locale=US\&languagc $=$ ENG\&homepg $=$ index_flash\&groupOID $=81$ 21 \&groupCatName=Ourcompany (last visited Apr. 1, 2002).

470. See, e.g., Purina, Linking to Purina.com, at http://www.purina.com/lcgal.asp?type=linking (last visited Apr. 1, 2002) (forbidding "[l]inks to http://www.purina.com other than a text link containing our domain name or a link containing [our] graphic banner"). "Deep linking" means posting a hypertext link to another's sitc that does not resolve to their default top page.

471. See, e.g., Texas Instruments, Texas Instruments Incorporated Linking Policy, at http://education.ti.com/global/linkpol.html (last visited Apr. 1, 2002) ("If you would like to link to TI's website, you must comply with the following guidelincs[:] . . Your site should not contain content that could be construed as distasteful, offensive or controversial.").

472. See, e.g., The Field Museum, Linking Policy, at http://www.fmnh.org/linking_policy.htm (last visited Apr. I, 2002) ("The Field Museum ordinarily does not prohibit links to its website, provided that any such link does not improperly connote an endorsement by or affiliation with The Field Museum, or otherwise adversely impaet The Field Museum.").

473. See, e.g., HealthyResources, Copyright and Online Usage, at http://www.hcalthyresources.com/cust-relations/copyright.html (last visited Apr. 1, 2002) ("We do not permit framing our pages-links which present material originating on this site within a frame or border that makes it appear as if our material were originating on another website."). "Framing" means loading another's site into a frame on the browser, while retaining the appearance of the initial site and leading the user to believe that the framed site emanates form the intial site.

474. See, e.g., Ticketmaster Corp. v. Tickets.Com, Inc., No. CV99-7654-HLH, 2000 U.S. Dist. LEXIS 12987 (Aug. 10, 2000); Washington Post Co. v. TotalNews, Inc., No. 97 Civ. 1190 (PKL) (S.D.N.Y. complaint filed Feb. 20, 1997). The same result obtained in the early Scottish decision Shetland Times v. Wills, Court of Session, Edinburgh (1996) (unpublished decision), available at $\mathrm{jttp} / / \mathrm{www} . j \mathrm{mls}$.edu/cyber/cases/shetld1.html. Recently a Danish court upheld the interests of a news service against an aggregator who was deep linking into the news service. See Danish Newspapers Assoc. v. Newsbooster, Copenhagen Crt, June 24, 2002, available at http://newsbooster.com/ ?p8=pressinfo I $4 \&$ lan $=$ eng.

475. See supra Part 111.B-C. 
the emergence of a default rule of exclusion. In some cases, this description may be unduly simplistic: the proliferation of unique "Terms of Use" sometimes creates no default rule at all, but a series of unique rules for access and use. The following section articulates the theoretical reason why this will lead to a terrible consequence. Before turning to the theory, it is worth considering a number of practical implications of an unchecked cyberspace enclosure movement.

First, searching the Internet will become more difficult and less thorough. The search engines that index the Internet and the Web will be severely constrained, for two reasons. The owner of an indexed site can stop search engines that rely on any kind of competitive business model, ${ }^{476}$ even one as simple as placing competitors' advertisements on the page where the indexed site is listed. The indexed site can draft "Terms of Use" forbidding this particular type of access. Even if this did not happen, the costs of assessing "Terms of Use" or using some sort of "de-authorizing" device would be prohibitive. We can say goodbye to new types of search engines that affect - in any way-the business models of the sites that they in$\operatorname{dex} .477$

Second, we will see the disappearance of aggregation products that were a boon to consumers and one of the more interesting features of the dot-com boom. AuctionWatch, for example, was a better product for many consumers than eBay, since it covered more auctions. ${ }^{478}$ However, eBay successfully shut it down using the trespass to chattels tort. ${ }^{479}$ Any innovative aggregation product is potentially subject to the same fate. This is true for comparison shopping agents, which find the most competitive price for a given product. ${ }^{480}$ Their vulnerability is evident: Why would Amazon or CDNow allow comparison agents to "invade" their sites and index them for the benefit of consumers, without any benefit to themselves?

Email presents a third issue. Intel Corp. v. Hamidi, a California decision, makes it a tort to send email to an address where the system proprietor has indicated that it does not wish to receive it. ${ }^{481}$ Does this mean that

476. See, e.g., Kelly v. Arriba Soft Corp., 280 F.3d 934 (9th Cir. 2002). In this case, the plaintiff, a professional photographer who posted his photos on the web, objected to the defendant's indexing of his photos. The dcfendant provided a service for consumers to search pictures on the web, by providing thumbnails of the pictures, among other things. The court concluded that the defendant had infringed the plaintiff's copyright. Though the case was framed as a eopyright dispute, the net effect was the same as the other features of the cyberspace enclosure movement: Internet indexing is becoming fragmented and ineffective due to individual enclosures that may not be accessed without permission.

477. Cf. id.

478. See supra note 288 and accompanying text.

479. Supra Part III.B.

480. See Brief of Amicus Curiae of Intemet Law Professors, eBay, Inc. v. Bidder's Edge, Inc., 100 F. Supp. 2d I058, 1060 (N.D. Cal. 2000), No. 00-15995 (9th Cir. June 22, 2000).

481. See Intel Corp. v. Hamidi, 114 Cal. Rptr. 2d 244 (2001), reh'g granted, 43 P.3d 587 (2002). Of course the spam cases discussed in Part III.B-C do the same, but might be distinguished on the basis that they deal only with spam, a particularly loathsome form of email. 
one must read the "Terms of Acceptable Email Usage" of every email system one emails in the course of an ordinary day? If the University of Pennsylvania had a policy that sending a joke by email would be an unauthorized use of its system, then under the logic of Hamidi, you would commit "trespass" if you emailed me a Calvin and Hobbes cartoon.

These are just some of the practical problems generated by the cyberspace enclosure movement. The next section argues that these practical problems are a consequence of a more general theoretical concern, a tragedy of the anticommons.

\section{B. The Tragedy of the Digital Anticommons}

A familiar argument in favor of private property is Garrett Hardin's "tragedy of the commons." ${ }^{\text {" }} 42$ A resource suffers the tragedy of the commons when it is prone to overuse because too many owners have a right to use the resource and no one has the right to exclude any other ${ }^{483}$ Exemplars are fisheries that suffer from overfishing, fields that are overgrazed, and forests that are overlogged. ${ }^{484}$ The tragedy of the commons is among the most compelling arguments in favor of private ownership of resources and against forms of commons or state ownership.

Until a short time ago, the tragedy of the commons was the only tragedy in town. However, Michael Heller recently introduced the concept of the "tragedy of the anticommons," and has systematically explicated its effect. ${ }^{485}$ The tragedy of the anticommons is, in many ways, the mirror image of the tragedy of the commons. Anticommons property exists where multiple owners have a right to exclude others from a scarce resource, and no one has an effective privilege of use. ${ }^{486}$ Heller's great insight was not in theorizing the existence of the tragedy of the anticommons; others had already suggested that anticommons property might exist in theory. ${ }^{487}$

Heller's dual contributions were to show how a limited number of exclusory rights would suffice to generate anticommons property and,

482. Hardin, supra note 434, at 1244-45.

483. This observation was made before Hardin. See H. Scott Gordon, The Economic Theory of a Common-Property Resource: The Fishery, 62 J. PoL. ECON. 124, 134 (1954) (providing an earlier description of the tragedy of the commons, using fishery as example); Anthony Scott, The Fishery: The Objectives of Sole Ownership, 65 J. Pol. Econ. 116, 116-24 (1955) (same).

484. See Hardin, supra note 434, at 1244-45; see also Heller, supra note 15, at 622, 624 .

485. See Heller, supra note 15; see also Hanoch Dagan \& Michael A. Heller, The Liberal Commons, 110 YALE L.J. 549 (2001); Michael A. Heller, The Boundaries of Private Property, 108 Yale L.J. 1163 (1999); Michael A. Heller \& Rebecca S. Eisenberg, Can Patents Deter Innovation? The Anticommons in Biomedical Research, 280 Scl. 698 (1998) [hereinafter Heller \& Eisenberg, Can Patents Deter]; Michael A. Heller, Three Faces of Private Property, 79 OR. L. REv. 417 (2000) [hereinafter Heller, Three Faces].

486. Heller, supra note 15; Heller, Three Faces, supra note 485, at 423-24.

487. See, e.g., Frank 1. Michelman, Ethics, Economics and the Law of Property, 24 Nomos 3, 6 (1982) (theorizing anticommons as opposite of commons, created by regulatory regime). See generally Heller, supra note 15, at 661-64. 
perhaps most important, to provide physical-world examples of anticommons property. ${ }^{488}$ Before Heller formulated his theory of the anticommons, there had been some literature on the anticommons as the symmetrical opposite of the commons. ${ }^{489}$ Since the commons was defined as property every member had the right to use, theorists assumed that the anticommons could only come into existence if every member had the right to exclude. Since "member" in this context meant any person, the requirement was thought to mean that an anticommons.would only occur if, and only if, every single human being could preclude other uses. This meant that, practically, the anticommons could never exist. Given such difficult preconditions, theorists were hard pressed to identify a physical world correlate, and therefore took the argument no further. ${ }^{490}$ Heller redefined the anticommons as occurring where multiple persons (but not everyone) had a right to exclude others such that no one had an effcctive (as opposed to perfect) right to use. ${ }^{491}$ Relaxing thesc conditions made it possible to see that a small number of people could effectively block the best use by others. ${ }^{492}$

$\mathrm{He}$ found his initial example on the streets of post-communist Moscow: large numbers of shops stood vacant while vendors hawked their wares from flimsy kiosks lined up in front. ${ }^{493}$ Heller askcd himself why these vendors stood around in the cold when they might use the empty shops immediately behind them. The answer lay in the complex set of entitlements to those shops that had been created in the transition to a market economy. ${ }^{494}$ There was such a tangled hierarchy of divided and coordinated rights that, in effect, no one was able to exploit the resource. Someone could always object to the use or hold out for the entire value of the resource. ${ }^{495}$ Once he observed the anticommons in action in the streets of Moscow, he was able to find other examples that previously had been ignored by the literature. The postearthquake reconstruction of Kobe, Japan, provided another telling example. Years after the earthquake, notwithstanding billions of dollars in aid, large tracts of Kobe remained in rubble. ${ }^{496}$ The reason for this was a "world class" tangle of property interests. ${ }^{497}$ Heller observed that "[i]n one block of Kobe, over 300 renters, lessees,

\footnotetext{
488. See Heller, supra note 15, at 627-60.

489. See Michelman, supra note 487.

490. See id., at 5-6.

491. See Hcller, supra note 15, at 625-26, 659; Heller, Three Faces, supra note 485 , at 424 .

492. See Heller, Three Faces, supra note 485, at 424-25.

493. Id. at 623-24.

494. Id. at 628-33.

495. Id.

496. Hellcr, supra note 15, at 664; Jathon Sapsford, Quake-Hobbled Kobe Shows How Land Law Can Paralyze Japan, WALL ST. J., Dec. 12, 1996, at A1.

497. Heller, supra note 15 , at 664 .
} 
landowners, and subletters own[ed] often-overlapping claims, ${ }^{, 498}$ and each one had to agree before rebuilding could begin.

Similarly, the CYBERSPACE AS PLACE metaphor and the concomitant digital enclosure movement are leading us to a digital anticommons. Consider the "property" at issue not as individual websites or email systems, but rather the commons property of the network resources: the Web or the email system that we all used to share. We used to enjoy a general and untrammeled "right" of access to websites, email systems, fileservers, and so forth. The cyberspace enclosure movement has led to a default principle of exclusion, with a billion unique terms providing the exceptions governing when we can "enter" these cyberplaces. The splintering of access rights is analogous to the overlapping rights on the Moscow street. Because of it, we no longer have a right to access the commons property. ${ }^{499}$

Return to the example of website "Terms of Use." A series of permission rules requires me to determine, every time I enter a website, whether my particular use is legal. In a world of zero transaction costs, this would not turn the commons into an anticommons. However, where transaction costs are real and where these costs are extremely high (as in the case of reading and understanding long tracts of legalese), no one has an effective right of use since these costs likely outweigh any conceivable benefit. The same is true for email, or any new protocol that the Internet can support: the old commons property ean easily be transformed into anticommons property.

Heller and Rebecca Eisenberg have argued that this is occurring with biomedical patents, most notably in the patenting of gene fragments. ${ }^{500}$ These fragments can be patented before researchers have identified any corresponding gene, protein, biological function, or potential commercial product. ${ }^{501}$ However, subsequent valuable products, such as therapeutic proteins or gene-based diagnostic tests, will almost certainly require use of multiple fragments. Thus, they argue, a small number of early owners of gene patents can create an anticommons for all. ${ }^{502}$

I take the same to be true for the digital anticommons. It does not take a large number of enclosed cyberspace places to create the digital anticommons. The law currently upholds the right to enclose and creatc these

498. Id. at 684 .

499. Dan Burk has previously noted that the effect of the trespass to chattels action might be to introduce anticommons property online. See Burk, supra note 285.

500. See Heller \& Eisenberg, Can Patents Deter, supra note 485, at 700-01. Their argument is controversial and not yet completely supported by empirical research. However, there is increasing evidence supporting the argument within other types of patentable subject matter. See Rosemarie $\mathrm{H}$. Ziedonis, When the Giants' Shoulders Are Crowded: Fragmented Rights and Patent Strategies in Semiconductors, at 7-10 (2003) (draft working paper, on file with author), available at http://www.law.upenn.edu/ilc/SeminarPapers/Ziedonis.pdf.

501. Heller \& Eisenberg, Can Patents Deter, supra note 485.

502. Id. 
new forms of private property on terms dictated by the proprietor's attorneys. The diligent network user now must take account of these new entry rules, and consequently transaction costs for all uses have risen dramatically. It will not take too many more lawsuits for us to see a significant change in behavior online. At this point, even though only a small number of rights holders block the uses, I believe that the anticommons will emerge. ${ }^{503}$

The penultimate point here is that the anticommons may be real without our realizing its existence. Empty Moscow shopfronts advertise the existence of the anticommons. ${ }^{504}$ The anticommons in gene patents is less obvious because we cannot know what innovative new commercial product would be developed without the anticommons: ${ }^{505}$ the anticommons owners make it impossible to combine the gene fragments in novel ways. Hence, the anticommons simultaneously precludes better uses of the resource and masks the recognition that better uses exist.

This invisibility is the most troubling feature of the digital anticommons. If we continue to mark out anticommons claims in cyberspace, not only will we preclude better, more innovative uses of cyberspace resources, but we will lose sight of what might be possible. The Internet was characterized by early innovative uses, such as content aggregation sites, shopping comparison agents, and so forth. Each of these created a better use of the resource than individual cyberplace owners could provide. In deeplinking cases like Washington Post Co. v. TotalNews, Inc. ${ }^{506}$ the competitor provided a more valuable resource by offering consumers one-stop access to the plaintiff's and other news providers' services. ${ }^{507}$ Similarly, in one of the trespass to chattels cases, Bidder's Edge's AuctionWatch site aggregated information from many auction sites, allowing the user to monitor multiple auctions. ${ }^{508}$ Legal recognition of anticommons owners' rights has stifled these innovative uses and will prevent others like them from arising at all.

This is not to say that every use that the courts have ruled against is better than the plaintiff's asserted use of the resource. It is hard to justify

503. I'm grateful to Mark Lemley for reminding me that the blocking undertaken by rights holders need not be economically rational. Note the blocking undertaken by the Scientologists, which can only be regarded as suppression of information. See Religious Tech. Ctr. v. Netcom On-Line Communication Servs., Inc., 907 F. Supp. 1361 (N.D. Cal. 1995); Religious Tech. Ctr. v. Netcom OnLine Communication Servs., Inc., 923 F. Supp. 1231 (N.D. Cal. 1995).

504. Heller, Three Faces, supra note 485, at 423 ("I developed 'anticommons' property... because I walked down a Moscow street and noticed an anomaly that the standard [aceount of property] ... could not explain.").

505. Heller \& Eisenberg, Can Patents Deter, supra note 485, at 700-01; Heller, Three Faces, supra note 485 , at 424.

506. See No. 97 Civ. 1190 (PKL) (S.D.N.Y. filed Feb. 20, 1997). This case settled out of court.

507. Id. at $8-9$.

508. Supra note 288 and accompanying text. 
spam under any conditions. Nonetheless, a significant number of cases demonstrates anticommons effects: use of the resource seems less efficient after the ruling than before. ${ }^{509}$ And, as with gene fragments, the anticommons not only blocks innovative use, but also prevents recognition that better uses might be possible.

The CYBERSPACE AS PLACE metaphor and the propertization of cyberspace are even more likely to create anticommons property in the future. Consider sites that aggregate content of other sites in order to meet the specific needs of users. After eBay v. Bidder's Edge, Inc. and TotalNews, it beggars belief that any new, innovative aggregator of multiple sites' content will succeed unless it licenses the content from each site that it aggregates. These sites will eithcr hold out for much of the value of the aggregation product (a characteristic strategy of smaller competitors) or, if they seek to build a competing aggregation product, will stonewall until the new entrant collapses (a strategy of large competitors). In neither case will the socially desirable innovation occur.

These examples demonstrate the gradually emerging digital anticommons. Because it is happening slowly we might be tempted to wait and see what eventuates before making any broad policy reforms. This is a mistake. Once anticommons property emerges, it gets locked into a suboptimal use pattern. As Heller notes: "Onee anticommons property is created, markets or governments may have difficulty in assembling rights into usable bundles. After initial entitlements are set, institutions and interests coalesce around them, with the result that the path to private property may be blocked and scarce resources may be wasted." 510 With perfect information, perfectly rational actors, zero transaction costs, and no path dependency, it would be simple to reassemble the interests into efficiently usable bundles. But in the physical world-with ordinary transaction costs, irrational actors, and strategic behavior-anticommons property is difficult, if not outright impossible, to rebundle. ${ }^{511}$ Anticommons property becomes stuck in its low value use, wasting resources, with low prospects of reassembling into higher value use..$^{512}$

Since it is so difficult to put the genie back in the bottle, we must address the anticommons before it emerges completely. In the next section, I present some suggestions for how we might confront the problem before the anticommons flowers.

509. See Kelly v. Arriba Soft Corp., 280 F.3d 934 (9th Cir. 2002); eBay, Inc. v. Bidder's Edge, Inc., 100 F. Supp. 2d 1058, 1060 (N.D. Cal. 2000); Washington Post Co. v. TotalNews, Inc., No. 97 Civ. 1190 (PKL) (S.D.N.Y. filed Feb. 20, 1997).

510. Heller, supra note 15 , at 659.

511. Id. at 625-26, 659; Heller, Three Faces, supra note 485, at 424 ("Once an anticommons emerges, eollecting rights into usable private property may prove to be brutal and slow.").

512. Heller, supra note 15 , at 626 ("When markets fail to rearrange initial endowments, resources can become stuck in low-value uses at either end of the property rights spectrum."). 


\section{Restoring the Commons}

There are two obvious ways to address the emerging online anticommons. The first is to challenge the underlying CYBERSPACE AS PLACE metaphor, which, 1 have argued, is the fundamental cause of the cyberspace enclosure movement. This turns out to be difficult. For the reasons advanced in this section, it is tricky to switch metaphors. The second approach is to challenge the cyberspace enclosure movement head on. This approach is slightly easier, but no more certain of success.

\section{Switching Metaphors}

An obvious response to the enclosure movement is to argue forcefully for supplanting the CYBERSPACE AS PLACE metaphor with another metaphor that would lead to more palatable public policy results. Or, we might do as some have suggested and abandon metaphors altogether:

$[\mathrm{T}]$ he best way to determine the rights and duties of participants in electronic networking communities is not to pick a particular metaphor to be our "map," but rather, to apply basie principles of fairness and justice and to use the existing "legal metaphors" only for what they are worth as illuminators of a principled discussion..$^{513}$

The cyberspace regulation literature has adopted various metaphors. Discussions of cryptography have often involved locks and keys. ${ }^{514}$ When examining privacy regulation in a networked database environment, scholars focusing on state control of personally identifying information invoked Orwell's Big Brother. ${ }^{515}$ Others suggested that multifarious private control of personal information proved analogous to "Little Brothers" 516 or

513. David R. Johnson \& Kevin A. Marks, Mapping Electronic Data Communications onto Existing Legal Metaphors: Should We Let Our Conscience (and Our Contracts) Be Our Guide? 38 VILL. L. REv. 487, 488 (1993).

514. Sce, e.g., A. Michael Froomkin, The Metaphor Is the Key: Cryptography, the Clipper Chip, and the Constitution, 143 U. PA. L. Rev. 709 (1995); Katsh, supra note 36.

515. See, e.g., Charles N. Faerber, Book Versus Byte: The Prospects and Desirability of a Paperless Society, 17 J. Marshall. J. Computer \& INFo. L. 797, 798 (1999) (describing "an Orwellian linkage of databases"); Bryan S. Schultz, Electronic Money, Internet Commerce, and the Right to Financial Privacy: A Call for New Federal Guidelines, 67 U. CiN. L. REv. 779, 797 (1999) (warning that "society inches closer to fulfilling George Orwell's startling vision of a nation where 'Big Brother' monitors the who, what, where, when, and how of every individual's life"). The same metaphor is also found in case law. See, e.g., Florida v. Riley, 488 U.S. 445, 466 (1989) (Brennan, J., dissenting) (adopting Orwell's Nineteen Eighty-Four to criticize the majority holding that viewing the defendant's greenhouse from a low-flying helicopter was not a search); United States v. Kyllo, 190 F.3d 1041, 1050 (9th Cir. 1999) (Noonan, J., dissenting) ("The first reaction when one hears of the Agema 210 [thermal imaging device used to detect heat emissions from the home] is to think of George Orwell's 1984. Although the dread date has passed, no one wants to live in a world of Orwellian surveillance."), rev'd, 533 U.S. 27 (200I).

516. See, e.g., Paul M. Schwartz, Privacy and Democracy in Cyberspace, 52 VAND. L. REv. 1609, 1657 n.294 (1999) (describing the proliferation of "Big and Little Brothers" collecting personal data). 
Kafkaesque powerlessness. ${ }^{517}$ Others have traced out various other metaphors, including the information superhighway, ${ }^{518}$ the frontier, ${ }^{519}$ or the Wild West. ${ }^{520}$ This would seem to lead to the conclusion that almost any metaphor is possible:

Since the inception of networked data communications systems, commentators have attempted to analyze the rights and duties of participants in these systems by mapping the systems against existing relationships in order to try to pick the "right" metaphor. These attempts, however, presuppose that there is some "best fit," some metaphor that will accurately characterize all the activities involved in these systems. In fact, the most significant attribute of "Cyberspace" is its malleability, the ability to change to fit a variety of metaphors. ${ }^{521}$

It would seem, then, that we could just supplant the CYBERSPACE AS PLACE metaphor with any other one that would lead to a more desirable outcome. Or we could, as the initial quotation in this section suggests, abandon metaphors altogether and decide according to some other principle such as "fairness."

As seductive as these ideas might appear, they just do not appear to be sustainable. First, we must recall the distinction between cognitive conceptual metaphors and the linguistic reflections of them. ${ }^{522}$ If we examine the potential alternative metaphors, we find that they reflect an underlying physical, space-based conceptual metaphor. References to doorkeepers, keys, maps, superhighways, frontiers, and the Wild West, all assume some

517. See Daniel J. Solove, Privacy and Power: Computer Databases and Metaphors for Information Privacy, 53 STAN. L. REv. 1393, 1413-22 (2001) (arguing for a "LOTS OF LITTLE BROTHER" metaphor).

518. Clay Calvert, Regulating Cyberspace: Metaphor, Rhetoric, Reality, and the Framing of Legal Options, 20 Hastings Comm. \& Ent. L.J. 541 (1998).

519. See Loftus E. Beeker, Jr., The Liability of Computer Bulletin Board Operators for Defamation Posted by Others, 22 ConN. L. Rev. 203, 205 (1989) ("[The] legal issues surrounding computer bulletin boards comprise a land with no maps and few native guides."); see also U.S. DeP'T of Justice, The Electronic Frontier (2000); John Perry Barlow, Jack In, Young Pioneer! (Aug. 11, 1994), at http://www.eff.org//publications/John_Perry_Barlow/HTML/Jaek_in_Young_Pioneer.html; Kapor \& Barlow, supra note 27; David R. Johnson, Barbed Wire Fences in Cyberspace: The Threat Posed by Calls for Ownership of Transactional Information (Apr. 4, 1994), at http://www.eff.org/1P/cyber_barbwire_johnson.article.

520. See Charles Doyle, Wanted-Cyber-Sheriff to Tame New Wild West, (Mar. 31, 1999), available at http://www.infowar.com/law/99/law_033199b_j.shtml (printed March 3, 2000); Tyler Hamilton, The Identity Thieves-Losing Face, ToRonto GlobE \& Mall (June 5, 1999), at http://www.infowar.com/class_1/99/class__050699a_j.shtml ("[T]he United States in particular has become a Wild West for mischievous mouseslingers."); John Makulowich, Wild West of the Information Age, WASH. TECH. (Mar. 22, 1999), at http://www.washingtontechnology.com/ news/13_24/briefs/433-1.html; Polly Sprenger, U.K. Cyberspace Is No "Wild West," Indus. STANDARD (Sept. 23, 1999), at http://www.thestandard.com/article/display/0,1 I51,6535,00.html. On the use of the metaphor within the legal discourse, see generally Rusch, supra note 5, at 578-79.

521. Johnson \& Marks, supra note 513, at 487-88.

522. See supra Part II.A-B. 
sort of abstract physical space that may be navigated ${ }^{523}$ This observation is at the core of the many linguistic examples explained previouslyexploring the net, navigating sites ${ }^{524}$-as well as the legal examples of trespassing, establishing public forums, and so on. ${ }^{525}$ The cognitive metaphor of CYBERSPACE AS PLACE is central to our understanding of the abstract idea of the Internet in all its various forms. We undeniably conceive of our online transactions and relationships as occurring within a space. Thus, the suggested alternative metaphors cannot help us. They all reflect the deeper cognitive spatial metaphor that is at the heart of much of the lay and legal understanding of cyberspace. By adopting these other linguistic metaphors, we are really just applying the same cognitive metaphor in a different context.

Alternatively, we might try to change the underlying cognitive metaphor. Unfortunately, this is a lot easier said than done. Lakoff's work demonstrates that we tend to conceive of the world in physical terms. ${ }^{526}$ It is unlikely that anyone will adopt a cognitive metaphor that is not physical. ${ }^{527}$ And it is extremely difficult to think of a physical metaphor for cyberspace that avoids the spatial characteristics that have led to the cyberspaee enclosure movement. As a result, attempts to supplant the CYBERSPACE AS PLACE metaphor are, I think, doomed to failure.

\section{Rethinking the Implications}

If it were possible, the main benefit of switching metaphors is the conceptual elegance of changing one assumption and thereby altering the outcome of the entire process. Given that I think this unlikely, the alternative route is, unfortunately, not as conceptually elegant. In essence, it is the oft-used mechanism of drawing attention to the policy implications of decisions.

The final part of this Article is devoted to doing just that. Other policy arguments are relevant here. For example, Carol Rose, Jerome Reichman, and James Boyle make an extremely strong case to treat intangible property differently from tangible property. They note that intangible property does not suffer from the same rivalrous use and excludability problems that

523. The BIG BROTHER metaphor may not be spatially oriented, but it does not appear to be a general model for eyberspace.

524. See supra Part I.B.

525. See supra Part III.B-E.

526. See supra Part II.B.

527. Several commentators on this paper have suggested metaphors that might answer this problem, most notably the metaphor of "communication" or "information" for the various features of the Internet. We have no way of knowing whether these metaphors, or any other, might be better than CYBERSPACE AS PLACE or, more importantly, whether they might be adopted at all. An alternative is to divide our understanding of cyberspace into an internaI and an external perspective, as suggested by Orin Kerr. See Kerr, supra note 379. 
tangible property does, nor is it subject to the tragedy of the commons. ${ }^{528}$ As a result, with the intangible property of cyberspace, we can throw out our normal assumptions about private ownership of the resources and recognize that a commons system might be the most efficient use of the resource. ${ }^{529}$ And moreover, even in the mostly privatized physical world, there are many public spaces and commons ownership of some resources.

Commentators have previously discussed these matters when considering cyberspace. ${ }^{530}$ Although the discussion was prompted by the emergence of the Internet, especially the idea that the Internet was one big copy shop, the argument is in fact over the fairly prosaic issue of the appropriate bounds of intellectual property protection in cyberspace:

The modern defenders of an open Internet take the position that the free exchange of ideas is a kind of comedy of the commons, where total creativity is enhanced by open access and interaction among all entrants' ideas. Hence the net, they argue, is an inappropriate vehicle for property's exclusive rights; instead, it is ... an open access regime. ${ }^{531}$

528. See, e.g., Carol M. Rose, Romans, Roads, and Romantic Creators: Traditions of Public Property in the Information Age, at http://www.law.duke.edu/pd/papers/rose.pdf (last visited Apr. 3, 2002). Rose argues:

It is widely thought that tangible matters entail two forceful Utilitarian arguments in support of exclusive property. The first is that exclusive property rights prevent wasteful overuse of resources and stave off the familiar Tragedy of the Commons that can follow open access. The second is that exclusive property encourages optimal investment in resource development, since the gains and losses from that investment come back to the owner. But in Intellectual Space, the first of these familiar arguments falls away, since there is no physical resource to be ruined by overuse: books and tapes and words may be copied, inventions may be imitated, pictures may be reproduced, all without the slightest damage to the original. Hence the Utilitarian case for exclusive rights in Intellectual Space rests entirely on the second argument, that the grant of exclusive property encourages appropriate investment in creativity.

Id. at 2 .

529. See Perspectives on Property Law xii (Robert C. Ellickson et al. eds., 2d ed. 1995) (giving examples of efficiently used common property); Carol M. Rose, Property as the Keystone Right?, 71 Notre Dame L. Rev. 329, 351 (1996) (identifying a number of different types of limitedcommons property systems).

530. See generally Carol M. Rose, The Several Futures of Property: Of Cyberspace and Folk Tales, Emission Trades and Ecosystems, 83 MiNN. L. Rev. 129, 150-62 (1998) (discussing cyberspace property regimes and arguing for limited-commons property).

531. Id. at 150-54 (citation omitted); sce also Marci A. Hamilton, The TRIPs Agreement: Imperialistic, Outdated and Overprotective, 29 VAND. J. TRANSNAT'L L. 613, 625 n.30 (1996) (explaining the hacker mantra of "information wants to be free"); Peter Jaszi, Caught in the Net of Copyright, 75 OR. L. REv. 299, 305-07 (1996) (arguing that the proposals of the U.S. Government's Magaziner Report on regulation of the Internet provide none of the traditional protections for open access); Johnson \& Post, supra note 6, at 1370-78; Jessica Litman, Revising Copyright Law for the Information Age, 75 OR. L. Rev. 19, 39-40 (1996) (noting Internet norms that run contrary to formal copyright law). Of course, the other side of the debate argues that information needs to be, or simply is, controlled. See R. Polk Wagner, Information Wants to Be Free: Intellectual Property and the Mythologies of Control, TPRC 2002, at http:/intel.si.umich.edu/tprc/papers/2002/75/ wagner.control.pdf. 
The debate has now moved to the Supreme Court, ${ }^{532}$ and will no doubt continue in the next decade.

However, this debate does not address whether we should grant the sort of quasi-property rights in cyberspace that are described above. This problem is perhaps easier to resolve than the difficult questions that arise in copyright or patent. We are simply talking about whether society's best interests are served by courts and legislators that grant a kind of quasiproperty interest to online resources providers. Unlike intellectual property, there is no strong moral claim that authors should be entitled to the fruits of their labors, else we risk freeriding, a reduction in innovation, and so forth. These proprietors have taken advantage of the network externalities that define the Internet, and they now assert private property rights that cut directly against it. As a matter of simple evenhandedness, then, the argument in favor of the cyberspace enclosure movement falls away.

\section{CONCLUSION}

Joseph Singer, the property theorist, explains that property is one of the strongest ordering systems we have in society. ${ }^{533}$ The kind of property that we have determines much of the society that we will have; thcrefore the social life that we want should dctermine the type of property that we allow. In the physical world, this means we choose to enact and enforce public accommodations statutes because we cannot condone racial segregation, or we abolish the fee tail because we can no longer stomach the disinheritance of women. ${ }^{534}$ " [P] roperty systems form the overall social context in which individuals live. They describe the limits of allowable social relations and channel interaction into certain patterns." 535

Online property interests are even more plastic than those in the physical world. Therefore we can determine first what sort of online environment that we want, and then, and only then, choose a legal regime to achieve it. The cyberspace enclosure movement threatens to reverse this process by forcing our physical property assumptions on the online environment where they are unnecessary, harmful, and wrong.

In 1992, the Internet opened to commercial exploitation. ${ }^{536}$ Relying on the public character of the Internet, and the vast public commons that was created before they ever arrived, commercial operators have grown exceedingly fat. They now have successfully exploited the CYBERSPACE AS PLACE metaphor, convincing judges to carve out remarkable new property rights

532. Eldred v. Reno, 239 F.3d 372 (D.C. Cir. 2001), aff'd sub nom., Eldred v. Ashcroft, 123 S. Ct. 769 (2003).

533. Joseph William Singer, Entitlement: The Paradoxes of Property 146 (2000).

534. Id.

535. Id.

536. Scientific and Advanced-Technology Act of 1992, Pub. L. No. 102-476, § 4, 106 Stat. 2297, 2300 (1992). 
online. By tiny, almost imperceptible stcps, commercial operators are enclosing cyberspace. They have mounted a campaign that has eroded cyberspace's public commons, and they threaten to create a genuine digital anticommons.

We have been lucky. We have witnessed an unprecedented decade of innovation on the Internet. This innovation has flourished in part because of the dot-com bubble, but more importantly because of the commons that cyberspace has provided, and the opportunity that this presents. The cyberspace enclosure movement, dependent on the CYBERSPACE AS PLACE metaphor, has not yet closed this off completely. However, if the current approach is not challenged, then little stands between us and an intractable digital anticommons-wherc low value uses beat out high value ones. It will be almost impossible to change this state. We will not be able to rebundle the various commons interests that we once shared. The opportunity will be lost forever.

We may already be past the point where we can do anything about this. I hope it is still a little way off. But unless we do something, as we all stake out our little private claim in cyberspace, the commons that is cyberspace will be destroyed.

And this would be the real tragedy. 
